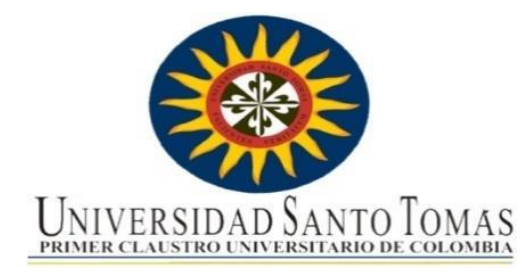

\title{
ANÁLISIS DE LA REPRESENTACIÓN MEDIÁTICA DE LA CONDICIÓN DE JUVENTUD EN LA SERIE TELEVISIVA "CARTAS A HARRISON"
}

\section{Mauricio Andrés Nájera Osorio}

\author{
Universidad Santo Tomás
}

Maestría en Comunicación, Desarrollo y Cambio Social

Bogotá, Colombia

2018 


\title{
ANÁLISIS DE LA REPRESENTACIÓN MEDIÁTICA DE LA CONDICIÓN DE JUVENTUD EN LA SERIE TELEVISIVA "CARTAS A HARRISON"
}

\section{Mauricio Andrés Nájera Osorio}

Trabajo de investigación presentado como requisito para optar al título de:

Magister en Comunicación, Desarrollo y Cambio Social

\author{
Director (a): \\ Magister Yaneth Ortiz Nova
}

Línea de Investigación:

Narrativas, representaciones y tecnologías mediáticas

Universidad Santo Tomás

Facultad de Comunicación Social

Bogotá, Colombia

2018 
En este largo proceso que me ha traído hasta aquí, haciendo este recorrido por las juventudes y sus representaciones, quiero agradecer a mi tutora Yaneth Ortiz, quien con su guía y orientación logramos sacar adelante este proyecto. De igual manera, agradezco a mi familia por apoyarme y acompañarme durante largas noches y momentos difíciles para la terminación de este trabajo. A la Universidad Santo Tomás, por brindarme las herramientas para poder sacar adelante esta investigación y finalmente, a todos los directores, escritores, actores y actrices que realizaron esa magnifica pieza como lo es "Cartas a Harrison" y mostrarnos a todos, un cuadro de nuestra juventud. 


\section{Resumen}

La presente investigación tuvo como objetivo analizar los elementos estéticos y de construcción de perfil que dan cuenta de una representación mediática de la condición de ser joven, en su identidad y posición sociocultural en el entorno ficcional producido y transmitido en los contenidos de la serie "Cartas a Harrison", que brinde comprensión de la manera en que se presentó a los jóvenes en la serie televisiva a mediados de los 90's. Esta investigación se enmarca en un paradigma hermenéutico y se utilizó una metodología cuantitativa, teniendo en cuenta que los análisis parten de la interpretación de los datos recogidos en la visualización. Se encontró que la representación hallada en la serie televisiva se corresponde con una representación heterogénea de la juventud, unas tensiones intergeneracionales que configuran al joven como agente de cambio y transformación social, configurando así una condición de juventud particular en la serie.

\section{Palabras clave: Juventud, Televisión, Teleserie, Representación Mediática, Colombia}

\section{ABSTRACT}

The objective of this research was to analyze the aesthetic and profile construction elements that account for a media representation of the condition of being young, in their identity and sociocultural position in the fictional environment produced and transmitted in 
the contents of the series "Cartas a Harrison", who provides understanding of the way in which young people was represented in the television series in the mid 90's. This research is framed in a hermeneutical paradigm and a quantitative methodology was used, taking into account that the analyzes start from the interpretation of the data collected in the visualization. It was found that the representation found in the television series corresponds to a heterogeneous representation of youth, intergenerational tensions that configure the youth as an agent of change and social transformation, thus configuring a particular youth condition in the series.

Keywords: Youth, Television, Teleserie, Media Representation, Colombia 


\section{Tabla de Contenido}

Pág.

Contextualización de la Investigación .......................................................................1

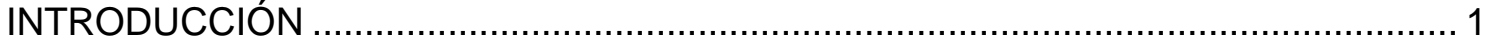

Antecedentes y Justificación ............................................................................... 5

Demarcación y Descripción del tema ..................................................................... 18

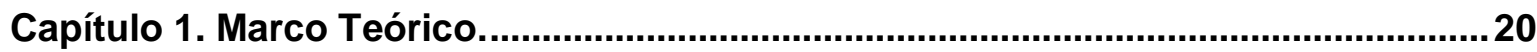

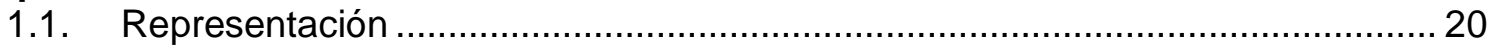

1.1.1. Definición de Representación Social ..........................................................21

1.2. Aspectos Teóricos relativos al estudio de la Juventud .......................................36

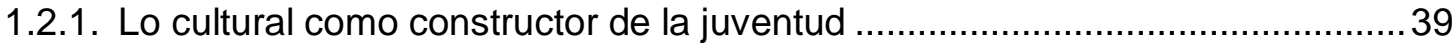

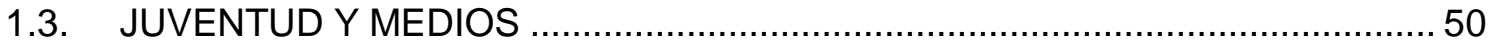

1.3.1. Los medios, instrumentos que ayudan a configurar la realidad personal........51

1.3.2. Imágenes juveniles en los medios ............................................................56

1.3.3. La imagen y la presencia de la juventud en los medios de comunicación. .....57

1.3.4. Construcción de perfiles de personajes en medios audiovisuales....................58

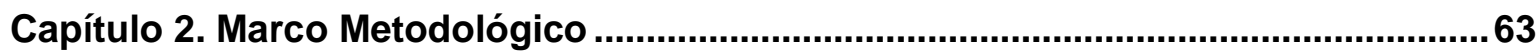

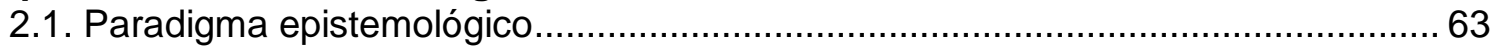

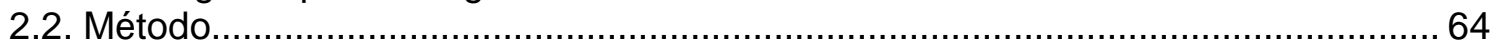

2.3. Técnica investigativa: El Análisis de Contenido ................................................. 64

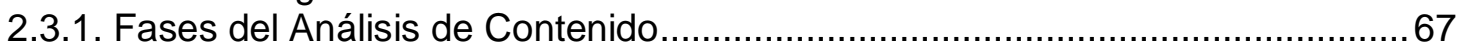

Capítulo 3. Presentación de Resultados ......................................................................75

3.1. ANALISIS POR CAPITULOS DE LA SERIE ................................................ 76

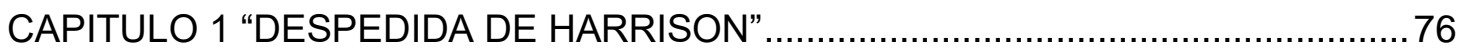

CAPITULO 2 "RADIO LORA",................................................................................... 81

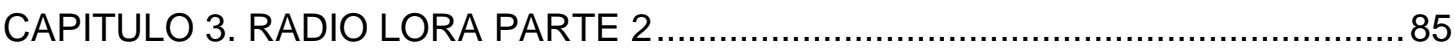

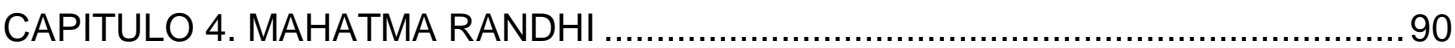

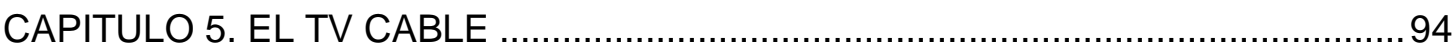

3.2. Organización de datos relevantes ................................................................. 97

3.2.1. Perfilación de personajes principales .......................................................... 98

3.2.2. Categorías emergentes a partir del análisis ................................................. 111

Capítulo 4. Discusión ..............................................................................................118

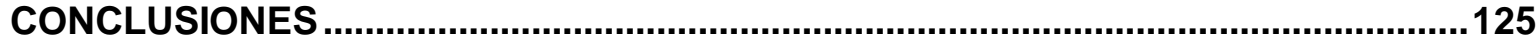

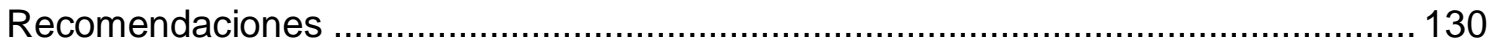

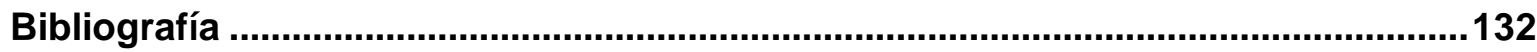




\section{Lista de Tablas}

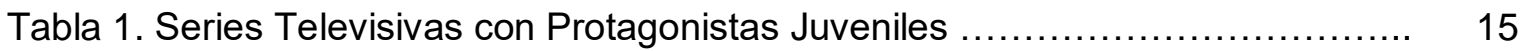

Tabla 2. Dimensiones y rasgos de la representación mediática....................... 28

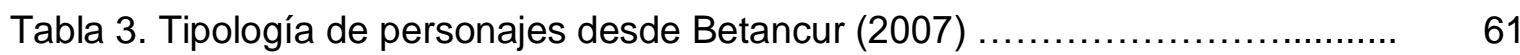

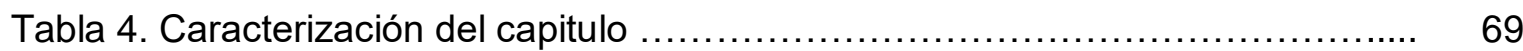

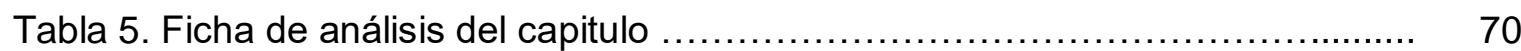

Tabla 6. Análisis de personajes (por relevancia en el capitulo) ..................... 71

Tabla 7. Matriz Temas en orden de aparición en la narrativa del capítulo.............. 72

Tabla 8. Matriz Temas / Tipo de Conflicto............................................................ 72

Tabla 9. Matriz Personajes / Conflictos / Valores............................................ 72

Tabla 10. Caracterización primer Capitulo....................................................... 76

Tabla 11. Ficha de análisis del primer capitulo................................................ 77

Tabla 12. Matriz Temas / Tipo de Conflicto en el primer capítulo............................ 79

Tabla 13. Matriz Personajes / Conflictos / Valores en el primer capítulo................. 80

Tabla 14. Caracterización segundo Capitulo..................................................... 81

Tabla 15. Ficha de análisis del segundo capítulo............................................... 81

Tabla 16. Matriz Temas / Tipo de Conflicto en el segundo capítulo........................ 83

Tabla 17. Matriz Personajes / Conflictos / Valores en el segundo capítulo.............. 84

Tabla 18. Caracterización del tercer capitulo...................................................... 85

Tabla 19. Ficha de análisis del tercer capitulo...................................................... 85

Tabla 20. Matriz Temas / Tipo de Conflicto en el tercer capítulo.............................. 88

Tabla 21. Matriz Personajes / Conflictos / Valores en el tercer capítulo................... 89

Tabla 22. Caracterización del cuarto capitulo...................................................... 90

Tabla 23. Ficha de análisis del cuarto capitulo..................................................... 90

Tabla 24. Matriz Temas / Tipo de Conflicto en el cuarto capítulo............................ 92

Tabla 25. Matriz Personajes / Conflictos / Valores en el cuarto capítulo................. 93

Tabla 26. Caracterización del quinto capitulo................................................... 94

Tabla 27. Ficha de análisis del quinto capitulo................................................... 94

Tabla 28. Matriz Temas / Tipo de Conflicto en el quinto capítulo........................... 96

Tabla 29. Matriz Personajes / Conflictos / Valores en el quinto capítulo................ 97 
Tabla 30. Perfil del personaje Harrison..................................................... 98

Tabla 31. Perfil del personaje Eric.............................................................. 99

Tabla 32. Perfil del personaje Albeiro.......................................................... 101

Tabla 33. Perfil del personaje Marisela............................................................ 102

Tabla 34. Perfil del personaje Nancy........................................................... 104

Tabla 35. Perfil del personaje Nacho............................................................ 105

Tabla 36. Perfil del personaje Lalo............................................................. 106

Tabla 37. Perfil del personaje Randy............................................................ 108

Tabla 38. Perfil del personaje Mireya ............................................................. 109

Tabla 39. Perfil del personaje Afranio........................................................ 110 


\section{LISTA DE IMAGENES}

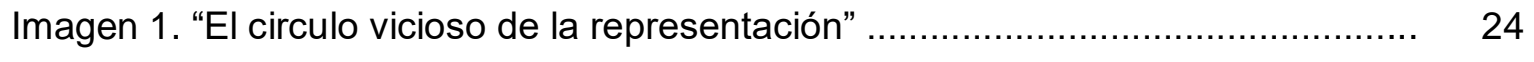

Imagen 2. Propuesta de análisis de personajes.................................................. 61

Imagen 3. Categorías Inductivas a explorar en la investigación............................. 66 



\section{Contextualización de la Investigación}

\section{INTRODUCCIÓN}

A través de la presente investigación, se pretende un análisis de la representación mediática $(\mathrm{RM})$ de la juventud desde sus estéticas, la construcción de personajes asociados a lo joven, sus valores y creencias en la serie televisiva Cartas a Harrison, serie producida y transmitida en Colombia a mediados de la década de los 90 , con el fin de reconocer la manera en que fue representada la juventud en ella, en clave comunicativa, y de cambio social, como una forma de acercarse a la condición juventud que se generó en los medios de comunicación audiovisual en nuestro país, facilitando la posibilidad que esta investigación sirva como antecedente para futuros proyectos investigativos que permitan dilucidar algunos procesos en donde se involucró el mundo juvenil.

Esto la hace pertinente en tanto se busca realizar un acercamiento a la manera en que los medios de comunicación, a través de la puesta en escena de contenidos televisivos generados y reproducidos en nuestro país, han venido representando la juventud, además se propone como un insumo para futuras investigaciones que aborden el papel de la juventud en las producciones de la ficción televisiva colombiana, como una forma de afinar los procesos de comunicación y cambio social que apunten a acercar este segmento poblacional con las realidades que demanda nuestra sociedad.

Esta investigación se enmarca en los lineamientos teóricos y metodológicos que se corresponden con la línea investigativa de Narrativas, Representaciones y Tecnologías Mediáticas de la Maestría en Comunicación, Desarrollo y Cambio Social, para poder realizar un acercamiento a sus objetivos investigativos y que le permiten generar una dinámica de encuentro entre diferentes posiciones para manifestar un dialogo de saberes sobre aquello que se estudia. 
Desde la Maestría en Comunicación, Desarrollo y Cambio Social, se pretende pensar en las posibilidades de la comunicación como campo de transformación de las realidades sociales en busca de condiciones de bienestar, dignidad y convivencia, en el marco de los derechos humanos, a partir del concepto de cambio social. Este documento, plantea precisamente partir del reconocimiento de la juventud en los medios de nuestro país, como una necesidad inicial que facilite el entendimiento de este grupo poblacional, y cuya producción investigativa en relación con los medios no es extensa, de tal manera que ésta pueda llegar a convertirse en un insumo para generar procesos de transformación en la producción televisiva y que brinde una construcción alternativa y cercana a la realidad juvenil de nuestros jóvenes del siglo XXI.

Este documento se encuentra dividido en Capítulos. En el Capítulo I se desarrolla el marco teórico que sustenta la investigación desde lo conceptual, iniciando con el rastreo de las apuestas teóricas que se ha construido sobre las representaciones, tanto en el contexto de las ciencias sociales como en el estudio de la Comunicación, comenzando por un acercamiento al tema de la Representaciones Sociales y concluyendo por una exploración por la corta tradición que ha tenido el concepto representación mediática en la literatura científica, sobre todo con los desarrollos latinoamericanos.

Se realiza una apuesta por las propuestas teóricas asociadas con las representaciones mediáticas, derivada del estudio de la representación social que se cristaliza en los productos audiovisuales presentes en la televisión. Por ende, parte de un reconocimiento del camino recorrido en el estudio de las representaciones sociales, en donde se recogen las propuestas de Moscovici, Abric y, particularmente, las de Ivana Marková y deriva posteriormente, en los desarrollos teóricos latinoamericanos sobre el concepto de Representación Mediática, dentro de los que cabe destacar a María Auxiliadora Banchs y a Sary Calonge, de quien se toma la definición conceptual y los componentes de la representación mediática.

Posteriormente, se hace un repaso de la conceptualización de la Juventud y las diferentes maneras en que ésta se puede construir desde un contexto sociocultural, de afuera hacia adentro o de adentro hacia afuera. Posteriormente, se tienden puentes relacionales entre la Juventud y los medios de comunicación, mostrando especialmente 
la importancia de estos en la construcción de elementos de identificación juvenil que generan cambios y transformaciones en el mismo grupo y en los contextos en los que se desarrollan.

Aquí se aborda el tema de la juventud como condición, más allá de las propuestas etarias y biológicas que conceptualizan este concepto, se realiza un acercamiento al mismo desde una concepción sociocultural y de construcción en movimiento, repasando para esto, elementos brindados por autores como Brake, Feixa, Lacalle, y desde la mirada latinoamericana, con Marcelo Urresti, Marcos Urcola y particularmente, con los desarrollos teóricos del sociólogo argentino Mario Margulis. Vale la pena reconocer dentro del desarrollo de conceptos teóricos alrededor de la juventud en nuestro país, los esfuerzos de la escuela de Animación Juvenil de Medellín que han generado documentación en donde se busca encontrar las condiciones socioculturales alrededor de la condición de juventud. En esta investigación la condición de juventud está enmarcada en su actuar en un contexto ficcional televisivo, por tanto, también se realiza un acercamiento a las diversas investigaciones que han relacionado como se ha presentado la juventud en diferentes ámbitos, épocas y países en la producción ficcional, tanto en películas como a nivel serializado.

En el Capítulo II, se estructura una propuesta metodológica que permita alcanzar los objetivos propuestos en la presente investigación. Desde lo metodológico, bajo un paradigma hermenéutico interpretativo, se acude al estudio de caso y se hace uso del análisis de contenido como técnica investigativa para recoger y analizar datos y establecer los acercamientos necesarios a la información para obtener la representación de la juventud que estuvo presente en la serie televisiva estudiada.

De esta forma, esta investigación se presenta como un elemento de análisis a tener en cuenta en tanto contribuye al debate (metodológico y teórico) sobre el reconocimiento y la construcción que se hace de los grupos sociales en los productos audiovisuales que se realizan en la televisión colombiana, además de contribuir con la reconstrucción del entramado social que soporta la vida en comunidad, desde la recuperación de las narrativas y discursos excluidos en el análisis de nuestros medios. 
En el Capítulo III se realiza la presentación de resultados, en donde se codifica la información recuperada a partir de la visualización de los capítulos que componen la muestra de esta investigación y se realizan los respectivos análisis desde la inferencia, para reconstruir una representación particular de juventud. Desde estos datos, se puede interpretar que la representación que existe de la juventud en la serie es heterogénea y más allá de hablar de una juventud con unas características particulares, alejada de las dinámicas sociales y contextuales que lo rodean, en esta serie se muestra una juventud plural, con diversas expresiones y que, en su gran mayoría, integra a la comunidad en las acciones que realizan y en su devenir en el barrio.

Precisamente, este es el punto de partida desde el cual se inicia la discusión en el Capítulo IV, en donde se contrasta esta manera de representar la juventud con lo dibujado por los autores recogidos en el capítulo referente al marco teórico de esta investigación, para encontrar puntos de encuentro y diferencias entre estos, además de revisar y discutir sobre los alcances de las propuestas teóricas y metodológicas alrededor de las representaciones mediáticas en el estudio de grupos sociales como objetos de investigación en el marco de los productos televisivos en general y en particular en nuestro país.

Finalmente, en las conclusiones se propone ampliar la necesidad de continuar con la búsqueda e investigación de elementos comunes y diferenciadores de los productos televisivos alrededor de la figura del joven en nuestro país, la manera en que se puede entender la relación de los jóvenes como personajes principales en la ficción televisiva (y por ende, en sus narrativas) y el papel que juegan en los procesos comunicativos para el cambio y la transformación social y el aporte que esta investigación puede brindar a nuevos procesos investigativos. 


\section{Antecedentes y Justificación}

En Latinoamérica, y particularmente en nuestro país, se ha generado de manera vertiginosa una necesidad de centrar esfuerzos y miradas hacia la juventud como un grupo poblacional con el cual es posible trabajar para generar procesos de desarrollo a largo plazo y con un alto impacto en el contexto. Como plantea el Informe de la CEPAL (Comisión Económica para América Latina y el Caribe), Informe Regional de Población en América Latina y el Caribe 2011 - Invertir en juventud (2011), hacer una labor sostenida para centrar esfuerzos en la promoción y participación de la juventud se instaura como un camino de doble vía en donde es posible observar estos como una necesidad y a la vez, como una oportunidad. En un informe posterior de la CEPAL, denominado "Juventud: realidad y retos para un desarrollo con igualdad" (2015), se recopilan diferentes avances en la Región respecto a educación, salud, participación política, inclusión social, pero se logra identificar que aún persisten brechas a nivel de ingresos, de carácter intergeneracional, de género, étnicas y territoriales, por lo que el mismo informe reconoce algunos retos que se deben abordar para mejorar el acercamiento a este grupo poblacional, y por ende, las condiciones de vida de estos en la región, el primer reto que propone tiene que ver con una de las intencionalidades de esta investigación, y hace referencia a la necesidad de establecer mecanismos que permitan identificar la percepción que se ha construido sobre este grupo poblacional en cada país y territorio. El presente documento busca, precisamente, revisar la representación que se ha dado en una serie televisiva que tuvo repercusión en los medios audiovisuales del país a mediados de los años 90, década de inicio de cambios económicos y socioculturales en Colombia, que aún se mantiene en constante dinámica.

Karime Lara (2008) en su tesis de grado "Consumo de televisión y cultura política", nos dice que los jóvenes tienden a tener una mayor propensión a aceptar el cambio frente a otros grupos poblacionales, facilidad en la generación de nuevas conexiones sociales, una relativa flexibilidad cognitiva para adaptarse al mundo cambiante que se encuentra en su contexto y una capacidad de influencia cada vez mayor en las decisiones económicas de los entornos familiares, lo que muestra a este grupo poblacional como un 
grupo objetivo con el cual es deseable incidir para producir cambios en las comunidades, los cuales modifiquen a largo plazo los modelos de bienestar del país.

Sin embargo, existen múltiples factores que tienen capacidad para afectar negativamente el éxito de iniciativas enfocadas en este grupo. La confianza general que la sociedad tiene en los jóvenes es contrastante con el número de proyectos de participación en los cuales se incluye este grupo poblacional (CEPAL, 2011), muchas de las problemáticas sociales que pueden ser referidas dentro de nuestra sociedad colombiana, han sido relacionadas tanto por los medios de comunicación como por el público en general, con los jóvenes, lo cual puede ser una fuente generadora de resistencias por parte de la comunidad para facilitar la participación de los mismos en los escenarios sociales, políticos y económicos. Según Abric (2001), las representaciones sociales hacen parte de la conformación y generación de las prácticas sociales desde y hacia los diferentes grupos sociales en sus relaciones con los demás y con los contextos. El encuentro que se genera entre prácticas sociales de diversa índole, tendría potencial para generar conflictos y tensiones entre los grupos sociales con diferentes condiciones, ya sean estas referidas a su pertenencia a los grupos etarios reconocidos, la condición socioeconómica e inclusive, las condiciones étnicas $o$ de género. Esto hace parte de las dinámicas generadas a partir de las representaciones sociales que se han construido a lo largo del tiempo en nuestra nación. El estudio de estas dinámicas es aún incipiente en nuestra producción intelectual toda vez que son pocas las investigaciones referenciadas que abordan estas temáticas en el país, sin embargo, es posible dar una mirada sobre algunos de los elementos del entorno próximo de los colombianos que tienen un alto poder mediatizador y moldeador de representaciones entre las personas. Uno de estos elementos, con alto impacto sobre la formación de representaciones, es la Televisión.

En términos de Duarte-Duarte y Jurado-Jurado (2016), la televisión ocupa un lugar relevante y concreto en la vida cotidiana, en tanto se configura en rutinas, prácticas y estilos de vida, por lo que asiste los procesos de socialización desde cambios en los hábitos mediante los cuales los sujetos son modelados socialmente en la medida en que estos van adoptando e interiorizando creencias, valores y normas de la sociedad a la que pertenecen. Al incorporar estos hábitos en la vida cotidiana, proveen una sensación una especie de "base segura" para afronta la vida colectiva. 
La televisión (TV), como herramienta tecnológica y medio de comunicación masivo, lleva poco más de 80 años en los entornos familiares de pueblos y ciudades alrededor del mundo. En nuestro país, la TV fue fundada como medio el 13 de junio de 1954, por el gobierno de Gustavo Rojas Pinilla como parte del proyecto político que la concibió como una herramienta de "educación popular" y "divulgación cultural" (Ramírez, 2000). En la actualidad, es uno de los medios con mayor presencia en el diario vivir del colombiano promedio toda vez que es posible hallar un televisor en el 92,4\% de los hogares colombianos de los cuales el $72 \%$ observan, al menos, una hora diaria de televisión al día, según la encuesta más reciente de medios realizada por el GEIH-DANE en el año 2015. El carácter masivo de la televisión y sus contenidos, en nuestro país, alcanza cotas muy altas lo que conlleva a pensar que la influencia que este medio ejerce en la creación y reproducción de saberes, ideologías y representaciones en nuestros ciudadanos es lo suficientemente alta como para plantearse la necesidad de revisar las diversas maneras en que se han visualizado y se han estado representando los diferentes grupos sociales que en ella se están evidenciando.

La televisión en nuestro país, con muchísima más fuerza y contundencia antes de los procesos privatizadores a los cuales se vio sometida, mediante su programación presentaba un panorama nacional compuesto y la perspectiva de la cultura colombiana, desde lo más tradicional hasta las fuentes recogidas desde afuera (Barbero, 2006). Representaban diferentes expresiones y actividades culturales de las personas pertenecientes a diferentes partes del país, por lo que era posible entender a la TV como un reflejo de la sociedad colombiana. Además, proporcionaba a la población una experiencia común en el tiempo, con alguna forma de verificación de la misma, esto hace que la comunicación de masas sea mucho más eficiente para los variados grupos que acceden a los contenidos televisivos.

Durante los años 90 la televisión colombiana sufrió un proceso de reestructuración que condujo a un reenfoque de los contenidos que a través de la misma se estaban brindando. En estos años, en nuestro país se empezaron a presentar cambios sociales, políticos, económicos y culturales profundos, ejemplificados en el agudizamiento de los 
conflictos sociales relacionados al narcotráfico, el conflicto interno con las guerrillas y la deslegitimación de la política que derivaron en una Asamblea Nacional Constituyente y en la creación de la Constitución de 1991 (UDEA, 1991), de la cual se desprendió una nueva organización de los servicios públicos, incluyendo los medios masivos de comunicación y en particular, la TV a través de su programación. Estos cambios, a su vez, pudieron haber influido en la población juvenil de nuestro país y en la forma en que tanto los adultos como los mismos jóvenes han estado representando a este grupo poblacional.

La tecnología nos ha entregado una herramienta importante en la televisión, en tanto medio como producto de masas. El poder realizar un acercamiento a la manera en la que nos estamos viendo, es una importante tarea a tener en cuenta en la generación de nuevos procesos de desarrollo y mejoramiento de la calidad de vida de nuestras comunidades, puesto que permite perfeccionar métodos y estrategias comunicacionales, a partir del reconocimiento de estos elementos, que favorezcan los procesos de construcción alrededor de los objetos sociales, tal como la juventud, y las tensiones a las que se confrontan. Se hace necesario, entonces, generar procesos investigativos que busquen la comprensión de la manera en que se han venido representando los jóvenes como grupo poblacional que conforman nuestro entramado social, que expresen las diferentes representaciones, en el caso de la presente investigación, de la juventud en la Televisión como medio, más específicamente las halladas en la serie televisiva Cartas a Harrison, para poder entender de una mejor manera el proceso de construcción mediática de la juventud y de las identidades que en ella confluyen. Esta serie fue seleccionada por presentar distintas maneras de ser joven en Colombia en un contexto natural de la juventud en nuestro país (el barrio) y utilizar diferentes herramientas narrativas para mostrar las relaciones entre el grupo y las relaciones intergeneracionales que se ponen en tensión, lo que es un espacio rico en elementos que pueden indicar una particular representación de la condición de juventud.

Al plantearse un análisis de estos elementos, a partir de la propuesta estética, de construcción de personajes y la representación de una condición particular en el medio, la presente investigación se hace relevante en tanto que la producción científica e investigativa existente sobre las representaciones mediáticas de la juventud, si bien han 
tenido recorrido en Hispanoamérica, en nuestro país aún se encuentra en proceso de desarrollo, con algunas investigaciones en campos como los estudios de audiencias, recepción y consumo, reseñados de manera interesante por Martin-Barbero y Téllez (2012) en su documento "Los estudios de recepción y consumo en Colombia", que brindan una mirada paralela a la intención de esta investigación y algunos documentos recopilatorios de la Escuela de Animación Juvenil, en la ciudad de Medellín. También de manera paralela en Latinoamérica se ha venido desarrollando una búsqueda dirigida a estas temáticas (audiencias, recepción y consumo) con autores como Orozco (2000, 2012) y Fuenzalida $(2002,2004,2008)$ y que brindan una mirada transversalizada de estas cuestiones desde lo propio de la cultura latinoamericana.

Aunque en los últimos años la producción investigativa en el país con respecto al tema de las representaciones en los medios de comunicación ha venido en aumento, es válido decir que el mayor volumen de estas se ha concentrado en el estudio de la prensa escrita más que en los productos audiovisuales. Con respecto a estos últimos, se han realizado esfuerzos para abordar como tema principal la manera en que se ha estado representando la violencia y el conflicto que ha marcado el transcurrir de la nación, por lo que el acercamiento a las representaciones de grupos sociales, se ha visto relegado a un segundo plano, sin tomar en consideración que es a través de la comprensión de la manera en que estos grupos se han estado presentando en la TV, es posible generar marcos referenciales de construcción social alrededor de estos. En cuanto al estudio de las representaciones de grupos sociales en la TV como medio de comunicación, se resalta la investigación realizada por Benjumea Flórez (2010), "Representación del adulto mayor en la franja Prime Time de los canales privados de Colombia (Caracol y RCN): Análisis de Contenido", en tanto que, de manera sistemática, intenta re-construir la representación de un grupo social desde los contenidos de los productos audiovisuales referidos en ese horario especifico en los canales privados de la TV colombiana. En esta investigación, el autor realiza un rastreo de los personajes presentes en los programas de la franja televisiva de mayor audiencia, conocida como Prime Time en el ámbito de consumo de medios, que se encuentran asociados con un grupo etario definido: personas en su vejez, principalmente, con la intencionalidad de describir una imagen del adulto mayor en la TV. Si bien es cierto que se trata de un trabajo primordialmente 
exploratorio y con intención de ser enteramente descriptivo, no acude a los conceptos abordados de representación social o incluso, de representación mediática aquí mencionados, lo que pudo haber enriquecido los análisis y permitir una visión un poco más profunda de los análisis de las representaciones de los grupos sociales en un entorno ficcional.

En este grupo también es importante mencionar el trabajo de Lina María Vargas Álvarez, "Azúcar: Un relato de raza y nación en la televisión colombiana" (2011), en donde la autora realiza un acercamiento investigativo a la representación de la población negra desde la narración ficcional de la telenovela "Azúcar", emitida a finales de la década de los 80 del siglo XX, utilizando para ello una metodología que denomino "etnografía de la ficción”, en la que, básicamente, aplicó un análisis de contenido entendiendo el espacio ficcional como un espacio de observación etnográfica.

Las investigaciones al referente de las representaciones en los medios de comunicación, en especial aquellos referidos a la prensa escrita, han delineado un marco teórico y metodológico congruente con los desarrollos teóricos aquí mencionados al respecto de la Representación Mediática, en tanto han pretendido rastrear los procesos de anclaje y objetivación (comunes a las RS) en los contenidos de aquello que ha sido presentado en el medio de comunicación social, acercándose a lo bosquejado por María Auxiliadora Banchs, que sería más tarde retomado y ampliado por Sary Calonge y Leonardo Tablante. Los tres autores que han estado generando dinámicas tendientes a estructurar una base teórica y metodológica solida al referente de las Representaciones Sociales son del vecino país de Venezuela, dotando así de una epistemología de fuerte raíz latinoamericana al estudio de la Representación Social en los Medios Masivos de Comunicación Social, particularmente la prensa, denominada por ellos mismos como "Representación Mediática". Aunque el término "Representación Mediática" no es fácilmente identificable en los ejercicios investigativos en nuestro país, si es posible identificar algunas propuestas investigativas que pueden ser asociadas a esta manera de tratar las RS en los productos de los medios masivos de comunicación, particularmente las relativas a representaciones de la pobreza y la violencia en nuestro país desde los artículos y noticias de la prensa colombiana. Nuevamente, los desarrollos en cuanto al 
estudio de estas representaciones en los productos televisivos han sido más restringidos en este respecto (Escobar et. al., 2004).

Encuentro particularmente llamativo hallar pocas referencias al respecto de las investigaciones que estudien las representaciones mediáticas de grupos sociales en productos audiovisuales, teniendo en cuenta el rico y amplio panorama de la producción televisiva colombiana en los últimos 60 años (Triana, 2014) y el enorme consumo de este medio masivo en el país (DANE, 2014), a pesar que la televisión, como fenómeno de consumo y de audiencias, si ha sido ampliamente estudiado. El abordaje de los contenidos cristalizados en los productos televisivos y aún más, las representaciones que se han estado haciendo de grupos sociales relevantes, como la juventud, aún se encuentra en mora en la academia colombiana, los elementos de estudio y análisis de elementos que enriquezcan los debates en los círculos académicos y de producción mediática y comunicativa, merecen ser ampliados de manera más extensa en la producción científica del país.

Aunque la intencionalidad de esta investigación no pasa por hacer una descripción detallada y exhaustiva sobre la historia de la representación de la juventud en la TV colombiana, entiende que es importante establecer un marco referencial con el cual guiarse para comprender mejor la elección de un programa en particular sobre los demás que hacen parte del acervo audiovisual con el que cuenta el país.

El más reciente artículo de los autores García Ramírez y Carlos Barbosa (2016), sobre el recuento de las investigaciones alrededor de la historia de la televisión en Colombia, encuentra falencias en el estudio mismo de los periodos históricos y la investigación que se ha desarrollado al respecto de esta temática, arrojando algunas luces sobre los procesos técnicos, tecnológicos y las relaciones entre los manejos gubernamentales y privados en la construcción de contenidos y programación en la TV del país. Sin embargo, los esfuerzos para realizar recuentos sobre programas (tipos, temáticas, horarios, etc.) a través de la historia de la parrilla televisiva, tienden a ser pocos y se centran más en reseñar algunos en particular, bien sea por el impacto mediático y económico obtenido, bien sea por elementos de interés nacional de los mismos. 
El más completo documento al que se puede hacer referencia sobre la historia de la televisión en Colombia, es el desarrollado por Caracol Televisión para celebrar los 50 años de la televisión colombiana (2004), en el cual se hace un recorrido por las diferentes décadas de desarrollo de la televisión en el país, no solo desde los apartados técnicos y comerciales, sino reseñando las diversas expresiones de contenido que ofreció la televisión a lo largo de los 50 años reseñados en el documento. Es curioso encontrar que, aunque se consideraron diversas categorías para abordar las reseñas de los programas y los contenidos (dramatizados, periodísticos, cultural, regional, infantil), no se contempló una categoría relativa a la televisión que hace referencia a la Juventud y se limita únicamente a reseñarlos como producciones enmarcadas en alguna de las categorías antes mencionadas, posiblemente, por el hecho que, a excepción de la producción alrededor de la figura del joven en los años 90, no existe en nuestra televisión un hilo conductor que permita identificar claramente estos programas como una categoría aparte a ser considerada como tal.

En general, el rastreo de investigaciones al respecto de la televisión juvenil en el país muestra una escasez llamativa en referencia a esta categoría, tanto en las reseñas que se han elaborado, como en el desarrollo de investigaciones alrededor de los programas inscritos en esta categoría. Algunas series, como "Pandillas, Guerra y Paz" han sido mencionadas en diferentes estudios sobre la violencia en la televisión, sin embargo, el aspecto relativo a la juventud como protagonista de la misma en la serie, no ha sido estudiado, ni considerado como un elemento de análisis a tener en cuenta para el desarrollo de estas investigaciones.

A partir del documento de Villa Orrego, "Televisión, jóvenes y políticas públicas. Aspectos clave de una relación que contribuye al desarrollo social" (2012), se desprende, de manera general, que el estudio de la relación entre jóvenes y medios de comunicación en nuestro país ha estado enmarcado en tres grandes grupos de investigaciones: la primera, más centrada en el desarrollo de la televisión pública y el análisis de los medios masivos de comunicación en el país (Herrán, 1991; Rey, 2002); un segundo grupo, más enfocado en las expresiones comunicativas y las relaciones de los jóvenes con su entorno, interpretados en las investigaciones relativas a las relaciones que se han dado entre las 
formas de comunicación que se han dado entre los jóvenes (Muñoz , 2007); sobre los jóvenes de la ciudad, el liderazgo y las identidades políticas; así como los programas de prevención de la violencia juvenil que se han puesto en marcha con el apoyo de los medios de comunicación (Vega, 2006; Garcés, Patiño y Torres, 2008; Pérez y Vega, 2010); finalmente, hace mención de un tercer grupo, que se ha ocupado de los jóvenes como audiencia de los medios, recogiendo aquí las investigaciones que se han centrado en estudiar el impacto y la influencia de la televisión en los jóvenes y de los perfiles de consumo de los jóvenes en contraste con otros grupos etarios (Arango y González, 2009; Sandoval, 2006; Aristizábal, 1996; Medina, Villa y Franco, 2003; Medrago Samaniego, Airbe Barandiaran y Palacios Navarro, 2010). En el artículo anteriormente mencionado de los autores García y Carlos (2016), "Historia de la televisión en Colombia: vacíos y desafíos", además de confirmar los grupos temáticos propuestos por Villa Orrego en el recorrido de las investigaciones alrededor de la televisión en Colombia y el enfoque con el cual se han estado abordando, se reconoce que se necesita seguir desarrollando nuevas expresiones investigativas en cuanto a la búsqueda de otros tópicos de referencia que aborden los contenidos de la televisión, tal como es la intencionalidad del presente estudio el cual alude a la búsqueda de la representatividad de la Juventud en una serie televisiva colombiana.

Aunque es posible hallar algunos esfuerzos que buscan encontrar representaciones de algunos grupos en la televisión y los medios de comunicación colombianos (Pedraza, 2008; Vargas, 2011; Pardo, 2012; Pardo, 2014), existe una evidente dificultad de encontrar referentes teóricos al respecto de los estudios de los contenidos de series televisivas con claro protagonismo juvenil en el país, por lo que se realizó una búsqueda en la documentación disponible de registro de los diferentes programas que podrían encajar en el perfil del objeto de investigación seleccionado. En el documento proveído por Caracol Televisión en donde se hace un extenso recorrido por la programación de la televisión nacional a través de las diferentes décadas desde la creación del servicio, muchos de estos programas fueron categorizados en el grupo de dramatizados, compartiendo categoría con telenovelas y melodramas, que han sido el fuerte de la producción televisiva nacional. Esto habla de una falta de claridad conceptual frente a lo que es la Ficción serializada y las diferencias que se pueden establecer con otros 
géneros dramáticos dentro de los contenidos televisivos. Por otra parte, este documento no hace mención a toda la producción que se ha desarrollado alrededor de la figura del joven en Colombia, por lo que se requirió acudir a las búsquedas en los archivos de periódicos nacionales, la revista Semana y archivos de la televisión presentes en páginas web como Colarte y KienyKe (2013), para encontrar referencias a estas series. Tras esta búsqueda se lograron identificar 12 series, recogidas a continuación en la siguiente tabla:

Tabla 1. Series Televisivas con Protagonistas Juveniles. Fuente: Elaboración Propia

\begin{tabular}{|l|l|l|l|}
\hline \multicolumn{1}{|c|}{ Nombre } & \multicolumn{1}{|c|}{ Año } & Productora & \multicolumn{1}{|c|}{ Temática } \\
\hline La U & $1985-1987$ & RTI & $\begin{array}{l}\text { Adaptación de la serie Paper Chase, } \\
\text { enfocada en la vida de los primíparos en } \\
\text { la Universidad y sus conflictos personales. }\end{array}$ \\
\hline $\begin{array}{l}\text { Décimo } \\
\text { grado }\end{array}$ & $1985-1990$ & Cenpro TV & $\begin{array}{l}\text { Abordo el tema de los conflictos en las } \\
\text { aulas escolares, inicialmente planteaba un } \\
\text { concepto pedagógico y la relación entre } \\
\text { educador y educado. }\end{array}$ \\
\hline pies a & $1993-1997$ & Cenpro TV & $\begin{array}{l}\text { A través del futbol como hilo narrativo, } \\
\text { cuenta las historias de un grupo de niños } \\
\text { en su transformación hacia la } \\
\text { adolescencia. }\end{array}$ \\
\hline $\begin{array}{l}\text { Clase aparte } \\
\text { Limón }\end{array}$ & $1994-1997$ & RTI-Cenpro TV & $\begin{array}{l}\text { Narra las peripecias y la vida de cuatro } \\
\text { adolescentes de clase alta de un exclusivo } \\
\text { colegio de Bogotá viviendo en sus vidas } \\
\text { opulentas y holgadas y viviendo además } \\
\text { la cotidianidad de sus familias, el colegio, } \\
\text { amigos, etc. }\end{array}$ \\
\hline $\begin{array}{l}\text { Otodos en la } \\
\text { cama }\end{array}$ & $1994-1997$ & RCN Televisión & $\begin{array}{l}\text { Siete estudiantes universitarios de } \\
\text { diferentes regiones de Colombia, } \\
\text { comparten un diminuto apartamento en } \\
\text { Bogotá, donde a pesar de las diferencias } \\
\text { culturales y de personalidad de cada uno, } \\
\text { forman una sólida amistad y se forjan } \\
\text { grandes lazos y hasta romances entre } \\
\text { algunos de ellos. }\end{array}$ \\
\hline $\begin{array}{l}\text { La historia contaba las aventuras de dos } \\
\text { hermanos que quedaron bajo la custodia } \\
\text { de su hermana mayor, después de que } \\
\text { murieran sus padres. Los hermanos se } \\
\text { convierten en grandes amigos, que }\end{array}$ \\
\hline
\end{tabular}




\begin{tabular}{|c|c|c|c|}
\hline & & & $\begin{array}{l}\text { enfrentan la vida diaria y aprenden de sus } \\
\text { experiencias. }\end{array}$ \\
\hline $\begin{array}{ll}\text { Cartas } & \text { a } \\
\text { Harrison }\end{array}$ & $1996-1997$ & $\begin{array}{l}\text { Producciones } \\
\text { Punch }\end{array}$ & $\begin{array}{l}\text { Recoger las vivencias y experiencias de } \\
\text { un grupo de jóvenes en un barrio quienes } \\
\text { a través de cartas a quien fuera el líder de } \\
\text { su grupo, construyen una narrativa frente } \\
\text { a sus relaciones y el entorno que los } \\
\text { rodea. }\end{array}$ \\
\hline $\begin{array}{l}\text { Conjunto } \\
\text { cerrado }\end{array}$ & $1996-1999$ & $\mathrm{RTI}$ & $\begin{array}{l}\text { Se narran las experiencias y situaciones } \\
\text { que acontecen a un grupo de jóvenes en } \\
\text { un conjunto cerrado en la ciudad de } \\
\text { Bogotá. }\end{array}$ \\
\hline $\begin{array}{l}\text { Francisco el } \\
\text { matemático }\end{array}$ & $1999-2004$ & $\begin{array}{ll}\text { Cenpro TV } & \text { y } \\
\text { Coestrellas } & \end{array}$ & $\begin{array}{l}\text { La historia se enfoca en un instituto } \\
\text { educativo distrital localizado en el sur de } \\
\text { Bogotá, donde Francisco Restrepo es } \\
\text { contratado para ser profesor de } \\
\text { matemáticas de noveno grado. Su } \\
\text { ambiente de trabajo fue compartido entre } \\
\text { estudiantes destacados, extrovertidos y } \\
\text { rebeldes. }\end{array}$ \\
\hline $\begin{array}{l}\text { Pandillas, } \\
\text { Guerra y Paz }\end{array}$ & $\begin{array}{l}1999- \\
2003 / 2004-2005 \\
--2009- \\
2010 / 2013-2014\end{array}$ & $\begin{array}{l}\text { Telecolombia y } \\
\text { Fox Colombia }\end{array}$ & $\begin{array}{l}\text { La serie abarca varios campos críticos en } \\
\text { la sociedad de las principales y más } \\
\text { aglomeradas poblaciones bogotanas, más } \\
\text { exactamente en la localidad de Ciudad } \\
\text { Bolívar, donde un pequeño grupo de } \\
\text { pandilleros fueron creciendo poco a poco, } \\
\text { hasta convertirse en los delincuentes más } \\
\text { peligrosos de la ciudad. }\end{array}$ \\
\hline $\begin{array}{ll}\text { A } & \text { mano } \\
\text { limpia } & \end{array}$ & $2010-2011$ & Cenpro TV & $\begin{array}{l}\text { Utilizando el boxeo como hilo conductor } \\
\text { de la historia, esta serie se adentra en las } \\
\text { dificultades de un grupo de jóvenes en un } \\
\text { entorno difícil marcado por la pobreza y la } \\
\text { violencia. }\end{array}$ \\
\hline $\begin{array}{l}\text { Mamá } \\
\text { También }\end{array}$ & 2013- 2014 & Teleset & $\begin{array}{l}\text { Un grupo de adolescentes (hombres y } \\
\text { mujeres), aunque de diferentes estratos } \\
\text { sociales, tienen algo en común: la difícil } \\
\text { realidad de un embarazo no planeado. A } \\
\text { través de sus historias conoceremos todo } \\
\text { lo que rodea el embarazo en la } \\
\text { adolescencia: los sueños truncados, el } \\
\text { rechazo de la sociedad, el machismo, la } \\
\text { adopción, el debate del aborto y la } \\
\text { indiferencia del estado. }\end{array}$ \\
\hline
\end{tabular}


A partir de la anterior recopilación se pueden sacar algunos datos interesantes. En primer lugar, la producción televisiva alrededor de la figura del joven estuvo concentrada en los años noventa de la década pasada (7 de 12), de los cuales seis (6) de ellos compartieron tiempo en la parrilla televisiva de la época. El resto de series se distribuyen así: Dos en los años ochenta. Dos que, aunque tuvieron su inicio finalizando la década de los noventa, se desarrollaron durante la primera década del presente siglo y finalmente, Dos que se produjeron y se presentaron durante la segunda década del presente siglo. Casi el $60 \%$ de las producciones nacionales enfocadas en los jóvenes como protagonistas de las narrativas que en ellas se contaba, se desarrollaron en la década de los noventa del siglo pasado y ocho de ellas antes de la entrada en vigor de la Privatización de la Televisión en el año 1998, ejercicio que aglutino la mayoría de los recursos creativos y de infraestructura con los que contaban los canales estatales Uno y A, por lo que la mayoría de productoras de televisión, que con el anterior modelo contaban con espacios fijos en las programaciones de los canales estatales, entraron en proceso de quiebre y cierre y aquellas que sobrevivieron a este proceso empezaron a adelantar producciones para los nuevos canales privados, RCN y Caracol, con una fundamentación netamente comercial diferenciándose así de la propuesta cultural y de representatividad social con la que se contaba antes de la privatización.

Igualmente, el $60 \%$ de los programas (7 de 12) fueron producidos por Cenpro Tv (42\%) y RTI (18\%), programadoras que actualmente se encuentran produciendo contenido para los canales privados de TV nacional. Esto habla del espíritu independiente y el interés que se centró en la juventud a mediados de la década del 90 por parte de las principales productoras de contenido en este periodo de la televisión nacional, coincidiendo con los movimientos sociales juveniles y la creación de estamentos gubernamentales dirigidos a promocionar y fortalecer la política pública juvenil en el país, a partir de lo propuesto por la Constitución Política de 1991.

Si se revisan los espacios en los cuales ocurre las narrativas ficcionales de las series aquí recogidas, se puede denotar que estas pueden ser diferenciadas en tanto en la gran mayoría se contaron desde espacios mediados por una normatividad e institucionalidad presente (la universidad, conjunto cerrado y la escuela) mientras que, en los otros, ocurrían en espacios no normativizados e institucionalizados, como el barrio. A este 
último grupo, pertenecen tres de las doce propuestas, en orden de aparición, "Cartas a Harrison" (1996), "Pandillas, Guerra y Paz" (1999) y "A mano limpia” (2010). Entre las tres series, solo "Cartas a Harrison" no cuenta con un elemento central que lleve el peso ficcional de la serie. Mientras que en "Pandillas, Guerra y Paz" se busca realizar un retrato de la violencia en los barrios populares de la localidad de Ciudad Bolívar (Bogotá), utilizando para ello el marco de las pandillas juveniles, en "A mano limpia", se buscaba mostrar como el boxeo podría ser una alternativa viable para superar la violencia en otro barrio popular de la localidad de San Cristóbal (Bogotá). Ambas series basadas en problemáticas y lugares reales de la ciudad de Bogotá. Por contraparte, "Cartas a Harrison", se centra exclusivamente en los jóvenes que en ella se representa, sus relaciones y la manera en que se contextualizan con su entorno, que de por si es un barrio ficcional de la ciudad de Bogotá, uno con características propias de una clase media. En esta serie, los conflictos varían de un capitulo a otro, sin llevar una aparente temporalidad conexa y secuencial entre los capítulos: lo que se muestra pudo ocurrir en cualquier momento de la historia, a excepción del primer capítulo, en donde se nos muestra al grupo de jóvenes que vamos a seguir y se enmarca la historia desde la partida de Harrison, personaje que es utilizado como vehículo para narrar todas las situaciones acontecidas a partir de "las cartas" que hacia el dirigen los muchachos del grupo.

La escogencia de la serie "Cartas a Harrison" como una elección viable para los efectos de esta investigación, se fundamenta en la realidad de quienes son los jóvenes presentes en el corpus de la serie, en tanto son jóvenes no normativizados ni mediados por una normatividad o institucionalidad presente, y sus expresiones se centran más en quienes son estos jóvenes, como resuelven sus dificultades, la forma que se relacionan con sus pares, los demás y el entorno, y como establecen la diferenciación entre ellos y el mundo adulto que está a su alrededor. 


\section{Demarcación y Descripción del tema}

Esta investigación aborda la representación mediática de la juventud en los medios de comunicación en el país a partir del estudio del caso de la serie televisiva "Cartas a Harrison", utilizando para ello el análisis de contenido el cual estará dirigido hacia la manera de articular las construcciones estéticas, los elementos particulares diferenciadores de los personajes involucrados en la serie televisiva que además dan cuenta del grupo etario particular al cual hace referencia y sobre el cual se basa para generar los procesos de identificación y de posicionamiento sociocultural, elementos en la trama que den cuenta de procesos de tensión intergeneracional y la manera en que los jóvenes en este entorno resuelven tales conflictos, elementos que pueden remitir a la representación de una condición particular de juventud.

Por lo anterior, y como una manera de establecer los alcances que este ejercicio investigativo propone, se plantean las siguientes preguntas:

¿De qué manera la representación mediática de la condición de juventud, en su construcción identitaria y posición sociocultural en la serie televisiva "Cartas a Harrison", brinda comprensión al referente del papel de la juventud en los procesos comunicativos y de transformación sociocultural en esta serie de mediados de los 90's?

A partir de esta pregunta investigativa, se derivan otras preguntas de segundo orden: ¿Cuáles son los componentes estéticos, de perfil psicológico y socioeconómico, de los personajes relacionados con una condición de juventud en la serie?

¿Qué creencias y valores se pueden identificar en los jóvenes de esta serie televisiva? ¿Cuáles son las tensiones intergeneracionales presentes en la serie que pueden dar cuenta de la posición social que ocupan los jóvenes en el espacio ficcional?

Lo anterior se traduce en los siguientes objetivos:

\section{Objetivo General}

Comprender el papel del joven en los procesos comunicativos y de transformación sociocultural desde lo presentado en la serie de mediados de los 90's "Cartas a Harrison" a través de un análisis de la representación mediática de la condición de juventud, en su construcción identitaria y posición sociocultural. 


\section{Objetivos Específicos}

- Reconocer las características de los perfiles de los personajes, en cuanto a sus elementos psicológicos, socioeconómicos, estéticos y la importancia de estos en la trama de la serie.

- Identificar las creencias y valores que se puedan encontrar en los personajes relevantes de la serie en el contexto en el que estos se movilizan como grupo social.

- $\quad$ Establecer las dinámicas de tensión entre los personajes jóvenes y los personajes adultos de la serie. 


\section{Capítulo 1. Marco Teórico.}

\subsection{Representación}

En tanto elemento de inicio para la comprensión de aquello que se quiere rastrear en este ejercicio investigativo, se hace necesario comenzar por delinear, a grandes rasgos, aquello que es una representación en el universo de las ciencias sociales, en donde se enfocan también los esfuerzos por estudiar los elementos relevantes a la comunicación social que permitan el acercamiento a elementos de transformación y cambio de las realidades sociales.

El término "representaciones" ha sido ampliamente abordado en las ciencias sociales para determinar una serie de fenómenos socioculturales que se ha venido estudiando a partir de diferentes enfoques y campos de estudio apelando a diferentes niveles de construcción desde lo individual hasta lo colectivo, muchos de ellos convergiendo en la construcción del concepto que se denominó "Representaciones sociales" y desde esta mirada se ha planteado la búsqueda conceptual de la presente investigación.

La conceptualización de las Representaciones sociales (RS), tiene antecedentes históricos en los trabajos de autores desde la psicología social y la sociología como Wilhelm Wundt, George Herbert Mead, Emile Durkheim y Gustave LeBon, cuyos trabajos son susceptibles de ser entendidos como construcciones previas al concepto base de las RS. Sin embargo, el concepto de Representación Social, de manera moderna y ampliada, fue introducido originalmente por Serge Moscovici en el año de 1961 con la publicación de "La psychanalyse, son image, son public" (El psicoanálisis, su imagen, su público). Se pasará entonces a explorar un poco sobre la conceptualización originaria y otras aportaciones posteriores que ampliaron el concepto de RS. 


\subsubsection{Definición de Representación Social}

Los aspectos fundamentales para la teorización de las RS, siguiendo a Jodelet (2003), se pueden identificar cerca de cinco aproximaciones teóricas actuales con cierta definición (antropológica, interpretativa, dialógica, estructural y de tomas de posición), además del enfoque inaugural planteado por Moscovici en 1961 como piedra angular de la teoría alrededor de las RS.

Las RS se definen como "un corpus organizado de conocimientos y una de las actividades psíquicas gracias a las cuales los hombres vuelven la realidad física y social inteligible, se insertan en un grupo o dentro de una relación cotidiana de intercambios y liberan los poderes de su imaginación"(Moscovici, 1961, p.27). Estas nos permiten generar un encuadre con los referentes proximales del grupo social en una forma de entendimiento común. Más ampliamente, las RS son "conocimiento de sentido común que tiene como objetivos comunicar, estar al día y sentirse dentro del ambiente social, y que se origina en el intercambio de comunicaciones del grupo social" (Moscovici, 1961, p. 77). El hecho de compartir RS nos permite estar al tanto de las referencias imprescindibles que forman parte de nuestro día a día.

La aparición de una RS es debida a varias condiciones, entre las que destacan tres (Moscovici, 1984): a) dispersión de la información: distribución desigual y selectiva de la información que circula en la sociedad; b) focalización: selección perceptiva sobre determinados aspectos de la realidad que responden a los intereses de cada individuo o grupo; y c) la presión a la inferencia: el sentido común extrae consecuencias o inferencias de informaciones o conocimientos que se consideran relevantes en un momento dado. Las RS no solamente se asociaron con la elaboración ingenua del conocimiento científico, sino con la elaboración simbólica de cualquier objeto social sujeto a discusión y controversia, o en su caso, importante para definir a un grupo social. En su trabajo fundacional y en varios escritos de difusión, Moscovici señala la existencia de tres componentes básicos en la pre configuración de las RS: a) la información, que se refiere a la sumatoria de los conocimientos que se tienen sobre un determinado objeto social, así como a la calidad de la misma; b) el campo de representación, que expresa la organización del contenido de una representación, la jerarquización de sus elementos y 
el carácter más o menos variado de éstos; y c) la actitud, que expresa la orientación positiva o negativa frente a un objeto. Asimismo, de este punto emergieron dos de los conceptos fundamentales de la teoría: objetivación y anclaje, que posteriormente serian retomados por Calonge para el desarrollo de su concepto de Representaciones Mediáticas, noción que desarrollaré más adelante. La objetivación es el proceso de recuperación de saberes sociales en una RS que hace concreto lo abstracto a través de la emergencia de imágenes o metáforas, la manera en que reconstruimos ese saber en objetos de reconocimiento social; y el anclaje, referido a la incorporación de los eventos, acontecimientos, significados extraños a categorías y nociones familiares en grupos sociales específicos (Valencia, 2007).

Uno de los enfoques en el estudio de las Representaciones Sociales que ha tenido relevancia y ha significado una base teórica de donde se retoma la conceptualización de las Representaciones Mediáticas, es el enfoque propuesto por Ivana Marková. Esta autora intenta desentrañar la epistemología dialógica que sostiene la teoría de las representaciones sociales, al mismo tiempo que retoma, discute y llama la atención sobre algunos conceptos básicos de la teoría que pueden presentarse como dialógicos (themata, objetivación, anclaje y géneros comunicativos). Este enfoque se basa en discusiones interdisciplinarias recurriendo tanto a fuentes filosóficas y literarias como históricas y científicas, para destacar el carácter dinámico del pensamiento, el lenguaje y las prácticas sociales. Se propone destacar y caracterizar el fenómeno de las representaciones en su dinamismo y en su carácter co-construido por las interdependencias entre lo social y lo individual. Desde esta perspectiva las representaciones sociales son fenómenos en constante producción, esto es, fenómenos en cambio social más que objetos estáticos (Markova, 2000).

En la línea de lo propuesto por Markova, María Auxiliadora Banchs elabora su conceptualización sobre las RS, integrando en ella su visión relativa al papel, cada vez más relevante, de los medios de comunicación masiva en la construcción de RS sobre diversos objetos sociales y la manera en que estos se encuentran interrelacionados:

"La forma de conocimiento del sentido común propio a las sociedades modernas bombardeadas constantemente de información a través de los medios de comunicación 
de masas (...) en sus contenidos encontramos sin dificultad la expresión de valores, actitudes, creencias y opiniones, cuya sustancia es regulada por las normas sociales de cada colectividad. Al abordarlas tal cual ellas se manifiestan en el discurso espontáneo, nos resultan de gran utilidad para comprender los significados, los símbolos y formas de interpretación que los seres humanos utilizan en el manejo de los objetos que pueblan su realidad inmediata" (Banchs, citada por Araya, 2002, p.28)

Esta definición, por reconocer la importancia de los medios masivos de comunicación en la conformación, configuración y anclaje de las $\mathrm{RS}$, es relevante para esta investigación y se tomara como punto de partida para abordar el concepto de Representaciones Mediáticas, principalmente estructurado desde la tradición investigativa latinoamericana.

\subsubsection{Representaciones Mediáticas}

La teoría de las representaciones sociales se presenta como un punto de partida desde donde es posible entender la responsabilidad social de los medios, en tanto se reconoce la centralidad del proceso comunicativo, en particular en nuestras sociedades modernas que presentan estructuras con enormes contenidos mediatizados, en las categorías en que se manifiestan las representaciones sociales. De esto último es posible desprender la urgencia del reconocimiento de la centralidad de la comunicación en la construcción de estos sistemas. Se trata, entonces, de un proceso de realimentación entre las representaciones sociales y los procesos comunicativos. A partir de este reconocimiento, algunos autores como Stuart Hall, desarrollaron conceptualizaciones alrededor del papel de los medios masivos de comunicación y factores asociados a la construcción de los objetos sociales.

Desde 1973, Stuart Hall empezó a esbozar lo que luego se conocería como el círculo de la representación refiriéndose a las prácticas de construcción de significado por parte de los medios masivos de comunicación. Esta idea desafía la visión antigua de que los acontecimientos tuvieran un significado único que se pudiera representar de manera "correcta" o "incorrecta", y de que pudiéramos medir el grado de distorsión entre la 
imagen y "lo que realmente pasó". (Hall, 1997) con su concepto de "círculo de la representación", Hall muestra que el mismo acto de representar constituye el significado de un evento, y que este sólo puede existir a través de la representación (y no antes).

Esto implica que las representaciones, igual que los acontecimientos, no tendrían ningún sentido si no estuvieran basadas en conceptos que comparten grupos de personas: los mapas de significado compartidos. Según los estudios culturales, los conceptos comunes o los mapas de significado compartidos son precisamente lo que llamamos cultura; la cultura de un grupo o una sociedad es su particular sistema de representación.

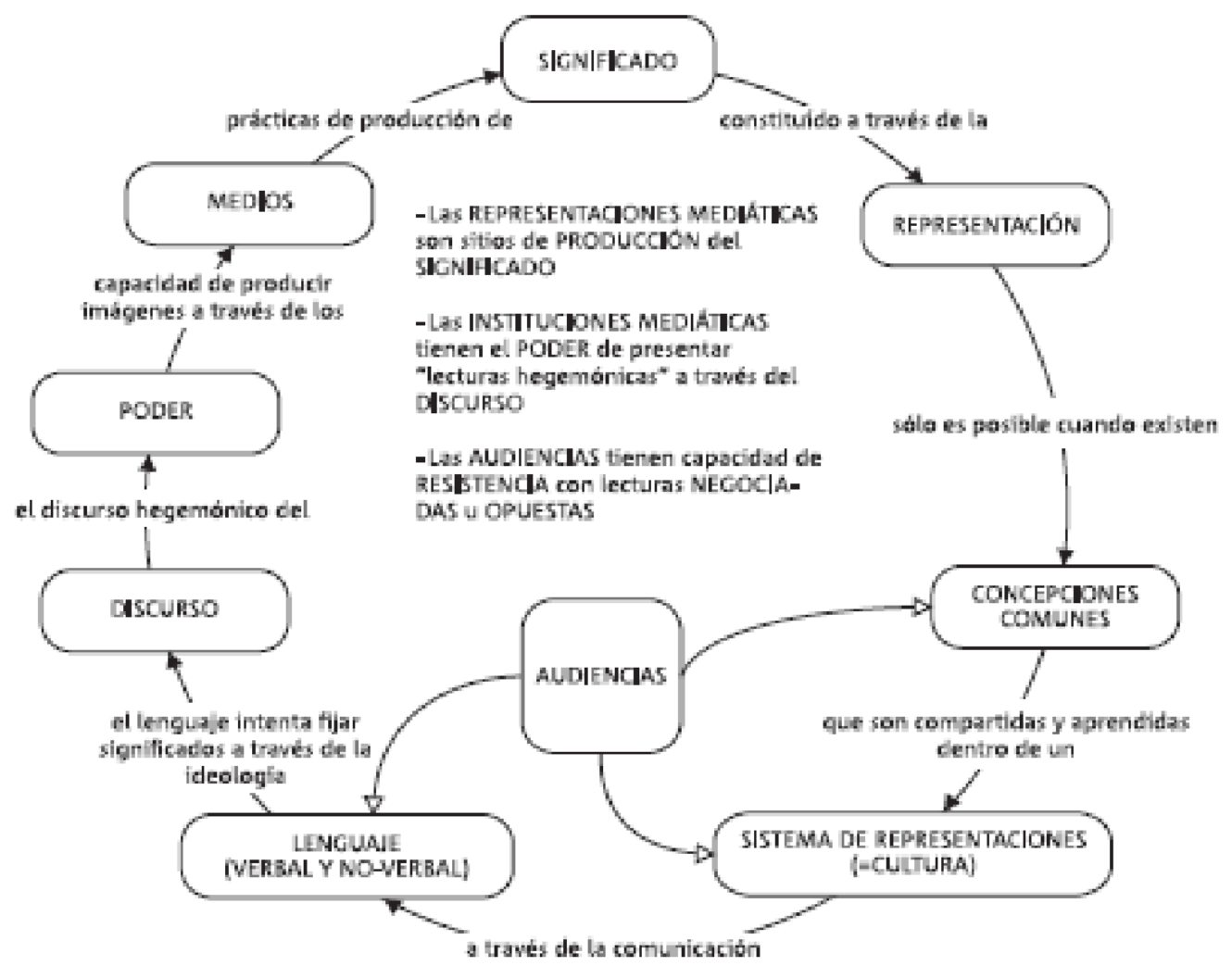

Imagen 1. Imagen tomada del texto "Minorías en red" Capitulo 2 "La deconstrucción de los discursos mediáticos" (Cilia Willem, 2011). Stuart Hall. "El circulo vicioso de la representación”. (1973, 1996, 1997)

En la figura, se presenta una relación circular en donde constantemente se están retroalimentando los significados desde los medios y la representación que se hace de 
estos en el mundo exterior y como, el discurso narrativo presente en sus contenidos, a su vez esta permeado por los poderes sociales dominantes.

Los medios masivos de comunicación ofrecen a través de su discurso, una serie de "imágenes [...] de las instituciones y sus acciones, [...] continuas interpretaciones [...] del entorno social y de lo que en su ámbito acontece, [que] contribuyen a mantener las representaciones colectivas y las visiones del mundo de los grupos o sujetos individuales, siempre y cuando, no se introduzcan visiones de la realidad diferentes" (Serrano, 1993, p. 53). Lo que se halla en los medios y sus discursos, en este sentido, produce de forma consistente y estructurada una expresa "representación social de la realidad cotidiana [...], que se manifiesta en la construcción de un mundo posible" (Alsina, 1993: p. 94).

Desde este punto, es donde es posible empezar a hablar de las representaciones mediáticas (RM) de la realidad social, en tanto se puede dar cuenta de algunos elementos característicos a ellas que advierten tanto el anclaje como la objetivación, ambos procesos de conformación de las representaciones sociales, como lo planteó Moscovici $(1981,1984)$. En el anclaje, en tanto los medios masivos de comunicación contribuirían en las posibilidades de categorización de la realidad social; en la objetivación, porque los escenarios planteados por los medios masivos de comunicación con sus elementos discursivos, se convierten en un espacio en donde es posible la cristalización de algunas realidades y de visualización de los conceptos inmersos en ellas a través las imágenes.

La representación mediática, en palabras de Leonardo Tablante (2008, p. 99) "designa la manera como los medios de comunicación social transmiten ciertos contenidos de interés colectivo. Esa manera -indisociable de la naturaleza técnica de los dispositivos mediáticos- determina el modo como tales contenidos se incorporan ulteriormente al discurso social y a la memoria de los individuos". Es decir, el medio de comunicación social se transforma en una especie de caja de resonancia de los contenidos que pueden interesar al colectivo para conformar un corpus de conocimiento que configuren tanto el discurso, como la memoria, pero es también importante resaltar que tanto para Tablante 
como Banchs, la representación mediática no solo depende de la audiencia y las construcciones sociales que hacen alrededor de los contenidos transmitidos, sino que además, el contenido en si mismo es susceptible a construcciones de significados alrededor de objetos sociales, de manera independiente a las audiencias que accedan al contenido.

En el proceso de construcción de una RM de los diferentes objetos sociales, según Adoni y Mane (1984), surgen tres aspectos: 1) Una "realidad social objetiva", expresada en lo que es posible encontrar más allá de la experiencia individual y que permite construir sentido en los actos cotidianos 2) Los símbolos asociados a la realidad social que es posible relacionarlos con diferentes formas de expresión de estos actos; y 3) la construcción de una realidad social desde el nivel subjetivo.

En ese orden de ideas, las RM toman gran significación en las sociedades que poseen un alto componente mediatizador en su configuración, y participan de forma decisiva en las formas en que los individuos incorporan a la construcción de su identidad, los imaginarios, las imágenes y los contextos provenientes de los productos mediáticos. Además, los medios desempeñan otra labor, y es la de la facilitación de la comunicación y puesta en común de la diversidad y la alteridad presente en la existencia humana: contribuyen con discursos, textos, imágenes y narrativas en la formación de los marcos comunes y públicos en el entorno próximo de las comunidades.

Aunque existen algunos planteamientos que han intentado aunar el papel mediatizador de los medios masivos de comunicación en la forma en que estos construyen, desarrollan y realimentan las RS, incluyendo la ya mencionada conceptualización de Banchs, para esta investigación es de particular importancia los acercamientos al tema que desde Latinoamérica, como la autora Sary Calonge Cole (2006) quien a partir de la teoría de las Representaciones sociales, ha venido construyendo un campus teórico y metodológico para el estudio de la expresión de las representaciones sociales en lo mediático y la manera en que estas pueden ser entendidas como un nuevo concepto que abarca diversos aspectos que se ponen en juego en la interacción de la sociedad y los sujetos con los medios de comunicación. 
La familiaridad con la que nos enfrentamos con los acontecimientos "reales" que recibimos a través de los medios nos habilita a darnos razones sobre lo que vemos y, más tarde, juntos en el mismo hábito de remitirnos a ella, sacar conclusiones de alcance general. La televisión, por ejemplo, presenta la evidencia visual de la existencia de muchas cosas. Daniel Dayan y Elihu Katz (1994) entienden la televisión como un medio que "construye la experiencia del acontecimiento", y que "le confiere existencia", por lo que es un generador de representaciones desde los contenidos de sus producciones.

Calonge extiende el concepto de representación con el adjetivo "mediática" desde el adjetivo "social" (Tablante, 2011, p.148). La "representación mediática" designa la manera en que los medios masivos de comunicación transmiten ciertos contenidos de interés colectivo, contenidos que se incorporan ulteriormente al discurso social y a la memoria de los individuos.

En su estudio sobre la representación mediática, Sary Calonge (1999) propone un esquema de estudio que se reproduce a continuación, toda vez que se considera importante para el abordaje y el estudio de las RM en los productos mediáticos que producen los medios masivos de comunicación.

Tabla 2. Dimensiones y rasgos de la representación mediática. Fuente: Sary Calonge

\begin{tabular}{|l|}
\hline Dimensión cognitiva \\
\hline Rasgos generales de la representación mediática \\
-Dos procesos formadores: la objetivación y el anclaje \\
-La esquematización del discurso \\
\hline Rasgos específicos de la representación mediática \\
- Focalización de los contenidos \\
-Cognición polifacética \\
\hline Las formas de conocimiento social y mediático \\
- Valores, creencias e ideologías \\
- Nexos \\
- Categorización social \\
-Atribución causal \\
\hline Dimensión pragmática \\
\hline
\end{tabular}


El discurso de los medios de comunicación social: Es el discurso de un objeto social. Se refiere al mundo que el medio pretende describir y construir. En ese discurso la función simbólica del lenguaje se actualiza en armonía con los lectores.

Espacio de la representación mediática: Son los espacios masificados, de consumo masivo. Las ciudades altamente pobladas.

El papel de la representación mediática: La representación mediática tiene un fin práctico de mediación entre las acciones e ideas del conjunto social y las prácticas y pensamientos de los diferentes grupos sociales.

Las condiciones de producción de la representación mediática: La representación mediática se produce dentro de mecanismos sociales muy complejos. En ellos están presentes las relaciones de poder económico y político y la idiosincrasia de los diversos grupos sociales de lectores.

Cole, 2006. p. 47.

La autora sostiene que la RM posee dos dimensiones, una cognitiva y otra pragmática. La dimensión cognitiva se refiere a "los trazos de orden cognitivo de la representación" (Calonge, 2001, p. 22), es decir, a los procesos que explican la formación de representaciones sobre la realidad en las conciencias individuales en contacto con los medios. La pragmática se refiere a las condiciones en que los medios de comunicación social transmiten sus representaciones y al vínculo dinámico existente entre sociedad y medios. Allí "se reúnen los trazos relativos a la acción de los individuos en vinculación con el medio de comunicación"(Calonge, 2001, p. 22). Entonces, la expresión de ambas dimensiones en relación con los productos mediáticos pueden ser rastreadas en dos direcciones: desde los contenidos y desde las audiencias. Esta investigación se enfoca en la primera de ambas vías para rastrear los elementos identificables de las representaciones. A continuación, se presentan los elementos constitutivos que dan cuenta de ambas dimensiones.

\section{La dimensión cognitiva}

Como explica Tablante (2011), siguiendo lo propuesto por Calonge, esta posee dos rasgos generales, uno que se relaciona con los procesos formadores de la representación social en la conciencia de los individuos -los ya explicados procesos de objetivación y anclaje y otro que tiene que ver con la esquematización del discurso, estos procesos parten desde el contenido proporcionado por el producto mediático al cual se está accediendo y que podría (o no) llegar a una audiencia. A esos dos rasgos generales 
se subordinan dos rasgos específicos: la focalización de los contenidos y la cognición polifacética.

Para Calonge (2006), la focalización de los contenidos, se refiere a "la tendencia de un medio de comunicación a insistir en ciertas materias mientras que descuida otras" (p. 83). En palabras de Calonge (2006, p.83) "la representación mediática [...] presenta una selección qua traduce tácitamente una exclusión".

Los símbolos y los indicios que la televisión nos presenta dan pie a que nos hagamos un mapa de cómo es la sociedad. En nuestro mapa mental, hay grupos que resaltan porque, en un momento dado, un canal de televisión, concentrado en un entendimiento particular de la sociedad circundante, les permitió sobresalir. Como lo anota Martín-Barbero: "Lo que los nuevos movimientos sociales y las minorías -las etnias, las mujeres, los jóvenes o los homosexuales- demandan no es tanto ser representados sino reconocidos: hacerse visibles socialmente en su diferencia" (2001, p. 6). Que la televisión enfoque un grupo social puede significar para este algo más que la adjudicación de reconocimiento y visibilización temporal. Si el marco y la sintaxis televisiva están a disposición de estos grupos, su discurso (verbal y visual) se verterá al espacio público para reforzar o generar nuevas representaciones sociales.

En el formato de la pantalla chica, y en sus diversos formatos programáticos, la televisión nos "encuadra": "[...] las instituciones emisoras nos suministran ciertos 'marcos' a los cuales corresponde esa 'información' [...]. Esos 'artificios de encuadre' sitúan un programa particular en el flujo de las emisiones y nos dan indicios para saber qué esperar de él" (Morley, 1996, p.8). Siguiendo la idea recién mencionada de Morley, la televisión llega más lejos en su empresa de codificar la realidad. Ella puede elevar al nivel de grupos "reconocidos" a los grupos sociales "representados" en alguno de sus bloques programáticos; ella puede fomentar el ascenso de la imagen que proyecta un grupo a imagen reconocida socialmente. Que la televisión fije su objetivo en un grupo social significa para él que puede hacer valer su imagen, porque esa imagen, difundida con recurrencia, podría llegar a estabilizar su identidad. La televisión nos brinda los signos que nos permiten trazar las coordenadas del mapa mental con el que nos 
explicamos el funcionamiento de la sociedad en su conjunto. La focalización de contenidos en la representación mediática puede equipararse al proceso de intelección individual, pero, a diferencia de éste, responde a los intereses de las personas que producen los contenidos en el medio masivo de comunicación.

Calonge (2006) continúa exponiendo los rasgos relativos a la dimensión cognitiva con la introducción del rasgo "cognición polifacética" el cual tiene que ver con la idea de que los medios masivos de comunicación -la televisión siendo el mejor ejemplo- son un conjunto diverso e inagotable de aspectos de la realidad. La constitución del discurso mediático es fundamentalmente polifacética [...]. Este carácter muestra la variabilidad de elementos cognitivos adoptados por la representación mediática, y esto se observa tanto en el ámbito de la interpretación como a nivel de los métodos y técnicas utilizadas como fuentes del discurso. Es decir, desde un medio de comunicación son transmitidos numerosos contenidos. Además, esos contenidos pueden transmitirse a través de géneros variados (dramáticos, informativos, de entretenimiento, etc.) que determinan las tácticas del receptor para decodificarlos.

En resumen, esta autora plantea cuatro formas de conocimiento social y mediático, que pueden ser agrupadas en dos categorías: los sistemas cognitivos y los procesos cognitivos.

Se pueden considerar como Sistemas Cognitivos: los valores, las creencias y las ideologías, en tanto que son estructuras más o menos permanentes que subyacen en la mente de las personas que intervienen en el proceso de conformación, reproducción y reconstrucción de la $\mathrm{RM}$ y que poseen un carácter más absoluto en la creación de contenidos y significantes. A continuación, se presentará una definición de cada uno de estos sistemas a la luz de la teorización de Sary Calonge.

Calonge se remite a la teoría de W. Lewin, quien explica los Valores (valencias) como estructuras dobles que disponen de un polo positivo y otro negativo. Las inclinaciones positivas permiten al individuo aceptar o, dado el caso, reaccionar hacia ese valor mostrado o experimentar placer frente a él. Los valores negativos van en sentido contrario. Los valores positivos que más se arraigan en el grupo social constituyen las 
normas sociales, que son un acuerdo grupal. Que una representación mediática sea o no aceptada por el grupo depende de si ella coincide o contradice esas normas sociales o de si sigue su trayectoria (Calonge, 2000). Las creencias son una "forma vaga de conceptos, y sus imágenes imprecisas son puestas en duda y revisadas a cada instante" (Calonge, 2000, p.40). Son preconcepciones compartidas socialmente, no sujetas a discusión (Calonge, 2000), que tienen la característica de ser flexibles y mutables, a diferencia de las ideologías, que son un sistema de creencias que se antoja categórica y permanente. Dentro de la tradición investigativa asociada a los contenidos televisivos y al análisis de los valores implícitos a estos contenidos, se hace relevante revisar la propuesta adelantada por Schwartz y expuesta por Medrano Samaniego (2006). Schwartz y otros, realizan una conceptualización de los valores en términos de "representaciones cognitivas con origen en las necesidades biológicas básicas, en las de interacción social y en las demandas de las distintas institucionales sociales. Aunque también se interpretan como una construcción individual de una meta transituacional (valores finales/instrumentales) donde las metas expresan intereses (individuales/colectivos/ambos) que tienen que ver con un dominio motivacional (disfrute, seguridad, logro, autodirección, conformidad, prosocialidad, poder social y madurez) y que estos intereses son evaluados dentro de un rango de importancia/no importancia como principios de actuación del individuo" (Medrano Samaniego, 2006, p.97).

Desde esta propuesta, se interpretan los valores como sistemas transculturales que se cimientan en aspectos con características universales que presupone compartimos los seres humanos a nivel psicológico y de los sistemas de interacción. Esto también acorde a la tradición proveniente de la psicología social al respecto de la relación entre los valores y las actitudes de los individuos frente a las situaciones a las que se ven abocados. Para Briñol, Falces y Becerra (2007), las actitudes juegan un papel preponderante en la conexión del contexto social en el que se vive con la conducta individual o, dicho de otro modo, la manera en que estas reflejan la interiorización de los valores, normas y preferencias que rigen en los grupos y organizaciones a los que se pertenece. Desde aquí, incluso, es posible reconocer las diferencias y particularidades de un grupo social y distinguirlo del resto a partir de distintas cuestiones o asuntos que comparten los individuos que los forman. 
La ideología niega o descalifica las creencias que se le oponen. Ellas anteceden la representación mediática de un objeto social particular. La ideología "constituye una condición, entre otras, de producción de representaciones sociales. Y el poder de la ideología se explica por el hecho de que ella transmite la creencia del carácter justo y necesario de la acción instituida" (Calonge, 2000, p. 41). Es decir, la ideología dicta la pauta del valor, positivo o negativo, que adopta una representación determinada.

En el proceso de constitución cognitiva de la RM, según Calonge (2006) es posible reconocer tres operaciones cognitivas de relevancias: los nexos, la categorización social y la atribución causal.

Para Michel Louis Rouquette (1994) los nexos, o contenidos pre lógicos que tienen una importante carga afectiva, pueden cohesionar a un grupo alrededor de ellos, aunque ésta no es fácilmente determinable. Poseen una enorme carga simbólica y tienden a tener un sentido únicamente en la colectividad y en la puesta en el ejercicio de la interrelación social.

Por otra parte, la categorización social es un modo de clasificación de la RM que se transmite a la RS. Este tiende a la comparación de unos y otros e incluso, a la distinción entre grupos sociales. Los miembros de un grupo social se reconocen como integrantes de ese grupo y toman distancia de individuos que consideran como pertenecientes a otro. En este mismo sentido, por medio de la atribución causal el individuo pretende aprehender la realidad y controlarla. Buscamos las causas de nuestra situación actual definiendo nuestro comportamiento y cobrando conciencia de la situación y el comportamiento de los individuos que no pertenecen a nuestro grupo. Es una herramienta que posibilita el establecimiento de puntos de referencia y que puede diseminar el prejuicio.

\section{La dimensión pragmática}

Desde lo que nos explica Tablante (2005) esta dimensión engloba, en primer lugar, el rol de RM, el cual consiste simplemente en mediar una manera de comprender y de sentir 
una realidad común instaurada en los diferentes grupos sociales existentes. En segundo lugar, comprende las condiciones de producción de la RM, las cuales son muy complejas porque ahí se expresan las relaciones de los poderes económicos y políticos y entra en juego la necesidad de tomar en cuenta la idiosincrasia de la recepción. En tercer lugar, esta dimensión incluye el espacio urbano de consumo masivo donde la RM participa (de manera exclusiva) conjuntamente con los procesos de identificación colectiva. Por último, tenemos el discurso mediático, el cual es diverso y se refiere a una amplia gama de objetos sociales que circulan en el entorno social.

El discurso del medio se refiere al conjunto de propósitos incluidos en un texto mediático sobre un objeto de la realidad social. Ese conjunto de propósitos constituye un lenguaje que describe y reconstruye simbólicamente el mundo. Los diversos discursos sobre la realidad de "los medios intervienen en la formación de una perspectiva común y sobre todo en la estabilización de una descripción y de un significado" (Tablante, 2005, p. 157). Los medios albergan los puntos de referencia y las convenciones que más tarde los miembros de la sociedad compartirán para intercambiar ideas sobre su circunstancia. "La construcción social del objeto, a través del discurso mediático, queda abierto a cualquiera que sepa [decodificar el mensaje] [...]" (Calonge, 2000, p. 81).

Siguiendo a esta autora el espacio de la representación mediática se relaciona con el o los ámbitos masivos por donde se insertan y circulan los mensajes de los medios. Este espacio es fundamentalmente de naturaleza urbana, puesto que, como bien lo apuntara en su momento Walter Benjamín, es en las ciudades donde se concentran las masas y donde las operaciones de los medios de comunicación, en virtud de corresponder con la sensibilidad y con el interés de esas masas, son más intensas. Los medios vuelven cotidianas experiencias estéticas tales como el cine o la fotografía y en ese sentido las despojan de la solemnidad de otras experiencias estéticas consideradas como más elevadas (la pintura o la escultura en el museo o en el taller de sus creadores) (Calonge, 2006).

El papel de la representación mediática tiene que ver con la función mediadora de los contenidos sobre la realidad transmitida por los medios. Estos contenidos no son la 
realidad misma, pero, a través de ellos, y en virtud de que ellos aspiran a ser considerados como reflejos fidedignos de sus referentes, un grupo social se hace una idea de lo que otro grupo hace o piensa y, a partir de esa idea, emite juicios. (Calonge, 2006)

La presencia permanente de contenidos alusivos a diversos grupos sociales en los medios masivos de comunicación nos permite figurarnos -a menudo erradamente- la realidad de esos grupos. Por ejemplo, tenemos el reflejo de generalizar a los jóvenes como personas que no aportan, que se dedican a la delincuencia, que no se interesan por las condiciones y las problemáticas de su entorno. (Nájera, 2015).

Siguiendo con otro de los elementos constitutivos de la dimensión pragmática, las condiciones de producción de la representación mediática tienen que ver con el enjambre de situaciones complejas y puntuales de las que dependen la transmisión e interpretación de un contenido mediático y, ulteriormente, la vida del propio medio. Según Eliseo Verón, citado por Calonge (2006), el medio está atado a su público a través de un "contrato de lectura". Ese contrato se establece por la necesidad del medio de tener un público, así como por la necesidad de ese público de disponer de una serie de contenidos mediáticos pertinente e interesante. Un medio puede darles visibilidad a problemas de interés social, a ciertos grupos sociales o a las autoridades públicas y puede, de igual forma, relacionarlos entre sí. Las condiciones de producción tienen que ver también con las relaciones de poder político y económico que posee un medio de comunicación dado y que determina el "tono" de los mensajes que transmite. Ese tono puede coincidir o no con la idiosincrasia propia de un determinado público receptor y puede definir los términos del mencionado "contrato de lectura". Una información referida a un grupo de jóvenes delincuentes de un sector específico de la ciudad, puede ser tratada por un medio masivo de comunicación que apoye ideológicamente el control y la segregación de los grupos juveniles. Ese mensaje puede gozar de la complicidad de un público que comparte implícitamente los valores y la filosofía de esa empresa de comunicación o puede ser juzgado de capcioso, o rechazado de plano, por un público unificado por otros valores y otra filosofía. 
La RM hasta aquí, puede ser entendida como un proceso de acciones que hacen aquellos quienes intervienen en el proceso comunicativo, tanto productores como público en general. Sin embargo, otra de las características base de las RM es lo que se encuentra en lo mental, en lo cognitivo: la manera en que los contenidos se construyen y se reconstruyen en la mente de las personas que intervienen en este proceso. Siguiendo la propuesta de esta autora, es relevante abordar la dimensión cognitiva de la RM, en sus procesos y operaciones.

En conclusión, la RM parte de un contenido propuesto desde los medios de comunicación, a través de los canales de transmisión de los cuales dispone y que bien puede llegar a una audiencia, como no hacerlo, hecho que no limita que este conlleve una representación de los objetos sociales circundantes en la comunidad; por tanto, puede estudiarse desde la representación cristalizada en el contenido como en las representaciones que las audiencias construyen a partir del contacto con este. Las dimensiones aquí propuestas como constitutivas de la RM pueden actuar entonces como filtros ya sea porque corresponden no con los criterios de pensamiento y acción de una persona dentro de un grupo social (valores), porque fomentan o inhiben el vínculo afectivo grupal y social (el nexo), porque reafirman o impugnan la distinción dentro de una sociedad (categorización social) o porque reafirman o impugnan criterios tradicionales de prejuicio y segregación (atribución causal). En definitiva, la construcción de la Representación en el medio correspondería a las dimensiones cognitivas de la RM, mientras que la puesta en práctica de los elementos que construyen una realidad a partir de tal representación, alude a las dimensiones pragmáticas de la RM. Toda vez que esta investigación busca indagar por los aspectos relativos a los contenidos cristalizados en una serie y no a sus implicaciones sobre la construcción de realidades en las audiencias del contenido, se limita a explorar los elementos relacionados con las dimensiones cognitivas de estos y no a los alcances de los elementos pragmáticos. 


\subsection{Aspectos Teóricos relativos al estudio de la Juventud}

En tanto esta investigación pretende hacer un análisis de una manera particular de presentar la juventud desde las Representaciones que de ella se cristalizaron en un producto televisivo, es importante realizar un acercamiento a que se ha entendido por juventud, a la vez de mostrar algunos desarrollos teóricos y conceptuales con respecto a este tema que puedan guiar y orientar la posterior discusión a la luz de los resultados que arroje el presente ejercicio investigativo.

Regularmente, se ha tendido a relacionar la idea de juventud con una categoría asociada más a una condición etaria (de edad) y que por tanto remite más a una relación bidireccional con la biología, el estado corporal y las capacidades que el individuo mantenga. Visto de ese modo, es una categoría vinculada al mundo natural antes que a una construcción social y cultural. Aun así, y aunque no se haga un análisis a profundidad del concepto, el significado de "juventud" se muestra como un concepto complejo, en el cual es posible caer en simplificaciones y tergiversaciones. El concepto, se relaciona con un grupo de significados y sentidos, elaborados a través de la historia, que dan muestra de un proceso social y cultural de construcción del sentido del mismo, dando así cuenta de un proceso en donde el entramado de actores sociales, procesos y escenarios dan como resultado un sujeto social altamente complejo de aprehender.

El concepto de juventud como condición, en tanto hace referencia a un grupo social que se hace susceptible a las transformaciones históricas, sociales, a nuevas conformaciones grupales, en definitiva, a una condición que va más allá de los géneros, la etnia y la estratificación social, convierte en poco relevante realizar la ubicación de las personas que se encuentran en esta condición desde una perspectiva meramente cuantificable, puesto que no es una condición resuelta y definida en su totalidad para ser considerada objeto a ser estudiado. Por el contrario, este concepto debe contener las diferentes aristas que construyan su sentido desde las diferencias sociopolíticas, históricas y 
culturales que determinen su alcance como elemento de estudio de las ciencias sociales y humanas.

El término "Juventud" hace referencia a una característica particular de construcción de identidad social de aquellos sobre los que se refiere. Genera un proceso de identificación en tanto establece una relación de diferenciación con el otro, y, por tanto, alude a un sistema de relaciones. (Taguenca, 2009) Es entonces en el desarrollo de un sistema de relaciones entre los diferentes miembros de una cultura en donde aparecen elementos tales como la edad y el sexo utilizados para organizar o clasificar socialmente a los grupos. En la sociedad actual la concepción de juventud aun resiste ser conceptualizada teniendo como referente único la edad, a ser considerada un reducto estadístico. Tanto es así, que se ha llegado a plantear que no existe una única y homogénea condición de juventud, sino que existen "juventudes" (Margulis, 2015). Es posible, entonces, dar una primera mirada a la juventud como una condición que está determinada y se construye teniendo en cuenta la historia, patrones culturales y sociales, cuya caracterización depende de diferentes variables.

En las sociedades actuales han desaparecido los ritos de pasaje y se ha reducido la capacidad de predecir cuáles serán los lugares sociales que ocuparán los grupos etarios (Margulis y Urresti, 1998). Entonces, es posible identificar distintas formas de ser joven en un amplio marco provisto por la heterogeneidad en aspectos tan diversos como los movimientos económicos, sociales y culturales, tal como lo plantea Margulis (2015), las juventudes pueden ser múltiples, variando en relación con características de clase, el lugar donde viven y la generación a que pertenecen, este contexto plural en el que pueden ser entendidas las diversas juventudes ofrece un panorama diverso y dinámico que comparte las conductas, referentes identitarios, lenguajes y maneras en que se construye la socialización. Así la juventud se transforma en el vehículo social en que la edad, se corresponde con una cierta condición mediada por factores como la diferenciación social, la inserción en la familia y en otras instituciones, el género, el barrio o, inclusive, las micro-culturas en las que pone en juego sus prácticas sociales. 
El sociólogo argentino Mario Margulis, además en un interesante artículo escrito en conjunción con Marcelo Urresti llamado "la construcción social de la condición de juventud" (1998), realiza un acercamiento a las diferentes dimensiones y conceptos relativos al estudio de lo juvenil desde las cuales se puede observar cómo se construye la realidad social que rodea el concepto de juventud en nuestra sociedad.

En un sentido similar, Urcola (2003), hace referencia a las representaciones sociales de los jóvenes en cuanto estas se construyen y se reconstruyen constantemente, por tanto, la cristalización de una definición del concepto de juventud es complicada, inestable e inacabada. De igual manera, plantea que en términos generales se puede ver como una representación en doble vía: como posibilidad de un futuro esperanzador o como futura desdicha y fuente de caos, en un constante ir y venir entre las tensiones sociales, culturales y representacionales en juego. Por ende, una definición sustantiva de lo juvenil solamente puede ser entendida como algo parcial. Para el autor, este concepto es complejo de abordar desde una realidad concreta que provea de una identidad con categorías lo suficientemente definidas que no acudan a estereotipos preconcebidos.

En algunos ámbitos socioculturales se asume el desarrollo de la condición humana desde un fenómeno de construcción permanente, en donde lo juvenil se convierte en un paso generacional previo en el proceso de formación para lo adulto. Los jóvenes son desde esta perspectiva, potencial de lo que pueden llegar a ser, negando así su ser presente en función de su ser futuro.

Los y las jóvenes se transforman en parte activa de su construcción como seres independientes e individuales. En este proceso, el joven se convierte en un sujeto social anclado en el ahora con capacidades suficientes para la transformación que sus entornos necesitan para la adaptación. De esta manera, se hace mucho más importante lo que es (joven) que la potencialidad de lo que va a llegar a ser (adulto). Esta posición lleva consigo una radicalidad en sí misma, en tanto niega o desconoce de igual manera las posibilidades que este joven tiene para la generación de su identidad en el presente, en detrimento de la figura del adulto futuro. Tal situación no solo repercute en la manera en que la sociedad aborda a los sujetos en condición de juventud, sino que además entraña serias dificultades para su asimilación en el entramado social, confrontándolos así a 
aquella que provisiona de identidad al mundo adulto: las instituciones sociales. El trasfondo de esta situación, más allá de una confrontación de carácter generacional, radica en asegurar la supervivencia del orden social preestablecido (Taguenca, 2009).

Es en esta puesta en escena de dos actores sociales distintos, en donde yace las dos posibilidades de construcción de lo joven: desde el paradigma conceptual adultocentrista, tomando la idea del joven como reproducción del adulto, negando de esta manera lo que es lo joven, la ubicación presente del mismo en los procesos de culturización; por otra parte, la posición constructiva desde lo joven, desde su ser presente, evitando tal construcción desde las posibilidades de futuro que en este se encierra, minimizando así la representación de lo adulto. Ambos caminos son contradictorios, por lo que es factible comprender desde aquí algunos procesos de marginalización de lo joven en la sociedad (Margulis, 2015). A través de la historia, aquello que no remita a la posición adultocentrista de la construcción de lo juvenil y que por el contrario asuma una posición de construcción desde las posibilidades inherentes a lo joven desde lo joven, ha sufrido de marginalización y estigmatización, mientras que, por el contrario, cuando se realiza esta construcción desde la otra orilla, toma un carácter casi que institucional, de aprobación generalizada (Taguenca, 2009). Se produce entonces un proceso en doble vía, por un lado, son rechazadas todas las expresiones asociadas con lo joven, en tanto estas remiten a estilos de vida e identidad alejados del modelo construidos por los lineamientos culturales dominantes. En la vía contraria, se da un proceso de homogeneización cuando quien define y establece que es y que deber ser lo joven es el mundo adulto, de acuerdo a las estéticas, valores y elementos acordes con la posibilidad de la reproducción de lo adulto en el mundo juvenil.

\subsubsection{Lo cultural como constructor de la juventud}

Es importante señalar la relación de la Cultura como marco referencial de elaboración social con la construcción de la identidad, la manera en que se toman decisiones en un marco de comprensión especifico y bajo situaciones concretas, las interacciones que se presentan, o pueden darse, en la interrelación de los miembros de los diferentes grupos 
sociales. Vale la pena revisar un concepto que se encuentra muy relacionado con el concepto de cultura y que, además, sirve de enlace para entender el concepto de juventud, tal como lo es el de Subcultura. Sobre este concepto, Mike Brake (1980) nos señala que es en la subcultura en donde se configura un trasfondo sociológico de comprensión de toda la interacción humana a partir de lo simbólico, en tanto que "Toma las reglas y las reconstrucciones como ingrediente activo de una relación dialéctica entre estructura y actor", es decir, la relación entre individuo y contexto brinda un marco de comprensión desde lo comunicativo pasando por lo simbólico de tal interacción. Además, plantea que, a nivel de identidad, esta se construye y se reconstruye a partir de los significados que se brindan a los elementos de la subcultura, brindando así una imagen que termina transformándose en la identidad de quienes pertenecen a tal subcultura, por tanto, esta puede considerarse el resultado de la interacción de los elementos característicos personales de los individuos y los elementos particulares de la subcultura en la que se insertan.

Es así como resulta determinante comprender como la subcultura sirve como marco referencial dentro del cual se organizan distintos valores, simbologías, reglas, imaginarios, conductas y espacios de práctica social de quienes tienen como referencia tal subcultura, y cómo este marco de referencia y aquello que lo compone son integrados o rechazados por la cultura dominante y quienes funcionan como actores dentro de ella. Siguiendo esta propuesta, Jonathan S. Epstein afirma que:

"Cuando las respuestas de un grupo están claramente en contra tanto en contenido como en estructura de la cultura hegemónica y con la cultura madre, y cuando estas respuestas son asimiladas por este grupo como modo de vida, entonces tenemos lo que se llama una subcultura". (1998, p. 10).

Posiblemente aquí radica la importancia de la subcultura en tanto hace visible una serie de patrones aceptados por una parte del grupo social de referencia, pero que así mismo, se establece como diferente del grupo social de base, dando un sentido a los comportamientos, que, de estos mismos patrones y prácticas sociales, se desprenden. Lo que algunos han denominado "tribus" o "clanes" dentro de la misma cultura juvenil, terminan siendo reconocidos como una particular forma de subcultura de esta. 
Al respecto, es importante acotar lo que nos dice Carles Feixa, citado por Maritza Urteaga (2005, p. 33):

"Para que exista la juventud debe darse, por una parte, una serie de condiciones sociales como normas, comportamientos e instituciones que distinguen a los jóvenes de otros grupos de edad y, por otra parte, una serie de imágenes culturales: valores, atributos y ritos específicamente asociados a los jóvenes. Tanto unas como otras dependen de la estructura social en su conjunto, es decir, de las formas de subsistencia, las instituciones políticas y las cosmovisiones ideológicas que predominan en cada tipo de sociedad."

Feixa, citado por Urteaga (2005), hace énfasis, en aquello que hace distintivo de quienes están en lo que socialmente conocemos como juventud frente a otros miembros de distintos grupos de edad, y que tal posibilidad es lo que explica mejor su existencia como grupo dentro del conglomerado social. La construcción de la identidad, entonces, tampoco puede ser reducida a un elemento de la diferencia existente entre los grupos sociales que conforman el conglomerado, jóvenes y adultos. La definición entregada por Feixa puede llegar a generar algún tipo de confusión en la construcción del concepto de juventud toda vez que no va más allá de la diferenciación de lo adulto, sin tomar en cuenta quien y como se construye este constructo en la práctica social. Desde aquí se puede entender este proceso como una peligrosa forma de igualación entre los componentes de la reproducción social desde lo joven como adulto en formación y desde lo joven construido desde lo joven.

Para esta investigación es de especial relevancia revisar el concepto que Feixa, citado por Urteaga (2005) quien propone alrededor de la definición de imágenes culturales, las cuales hacen referencia a:

1) conjunto de atributos ideológicos, valores y ritos asignados específicamente a los jóvenes; 2) universo simbólico que configura su mundo, expresado en objetos materiales (como la moda y los bienes de consumo) y en elementos inmateriales 
(la música, el lenguaje, las prácticas culturales y otras actividades). Las imágenes culturales son producto de las elaboraciones subjetivas de los jóvenes o de las instituciones que intervienen en su mundo.

A partir de la construcción cultural mediada simbólicamente es posible entender el establecimiento de algunas tipologías que brindan características particulares, a pesar de sus características generales y que representan distintas minorías dentro del grupo mayoritario entendido como el de los jóvenes enmarcados también en relación con una cultura distintiva que puede llegar a permear a la sociedad en su conjunto. Posiblemente, esto puede explicar mejor el interés de los productos audiovisuales en un álgido periodo de tiempo de cambios y transformaciones sociales, como lo fueron los años 90, alrededor de la figura del joven: Se comprendió que el acercamiento a sus construcciones sociales y culturales, podría acortar las brechas generacionales, creando nuevas dinámicas de interrelación y comprensión entre distintos grupos.

\subsubsection{Estéticas de lo juvenil: en búsqueda de una identidad y un referente de pertenencia}

Dentro de las posibilidades de acercamiento a la figura del joven, a sus elementos de construcción y configuración de lo juvenil desde la cultura y lo subcultural, el papel que juega la moda y las estéticas del cuerpo (y sus accesorios) han tenido una discusión constante en los círculos académicos e investigativos alrededor de la condición juvenil. Autores como Martin-Barbero (1998), Cevallos (2005), Reguillo (2007), Urteaga (2011), señalan la importancia que tiene para el joven establecer una estética particular desde la música que escucha y consume, la forma en que lleva el cabello, las prendas de vestir que utiliza y los accesorios que utiliza para brindar una figura identitaria y una pertenencia a un subgrupo cultural particular.

Una estética particular representa una experiencia significativa que relaciona, visibiliza y proyecta; que, cuando ésta se desgasta, se renueva. Su ropa y accesorios constituyen extensiones culturales que ayudan a la tarea de regir la vida y ordenar las prácticas sociales (Rico Bovio, 1998), y van configurando lo que se ha dado a conocer como culturas juveniles. Para Cevallos (2005), las estéticas hacen parte del capital simbólico 
que poseen los jóvenes para transitar por el mundo como constructor de realidades y a partir del reconocimiento de este capital simbólico es posible la construcción de nuevos imaginarios sociales que medien la conflictividad con el otro y mejoren la convivencia social, de ahí la importancia de explorar estas expresiones estéticas en la comprensión de una condición de juventud determinada y construida desde diversos elementos.

El cuerpo en tanto posibilidad de distintos valores, es lo único que les pertenece; a través de lo que expresan en su piel, su ropa y accesorios se comunican y transmiten diversos mensajes, mientras más cercanas al cuerpo, es más íntimo su sentido de propiedad, y lo que está en juego es su referente-mundo: el vestido, por ejemplo, no tiene como destino exclusivo cubrir la desnudez sino dar una forma particular de su presencia subjetiva en el mundo; es uno de los elementos de identidad, no solo desde una perspectiva de género, sino, sobre todo, desde la relación que se establece con los otros (Tenorio, 1999), incluso, y de una manera más amplia, se pueden transpolar elementos como los accesorios, los tatuajes, las expansiones y los piercings a nivel de un emblema que provee una identificación entre iguales y a una diferenciación de los otros (Reguillo, 2000). De esta manera, es posible entender la estética como una forma de ser y estar en el mundo, una posición vital frente a las condiciones que contextualizan y dan sentido al ser joven en una realidad y momento concreto.

Las estéticas juveniles hacen parte de aquello que se encuentra en lo cotidiano en los ambientes urbanos, sin desconocer que se pueden presentar en espacios rurales con menores impactos en el tejido social y sus formas son menos pronunciadas (Cevallos, 2005). La influencia de las industrias culturales, medios de comunicación y redes de consumo, como "promotoras y transformadoras de sentidos", constituyen una variable importante en tanto promueven, transforman, diseñan, facilitan y configuran cierto tipo de percepciones, de aparatos y lógicas cognitivas de prácticas, sentidos y sensibilidades; su uso social implica percibir de determinada manera y, por tanto, influyen en las formas de presentarse al mundo.

Para Tenorio (1999), el valor de la moda está dado por la cercanía que sostiene con las expectativas y los sueños. De esta manera, el joven no solo se convierte en caja de 
resonancia, reproductora y consumidora de formas sin fondo, sin significados, sino que paraleliza sus gustos con ideologías y estructuras propias sobre quién es y su lugar en el mundo. Es decir, la estética y la moda pasan a ser elementos que descubren una forma particular de entender la realidad y posicionarse frente a ella. En definitiva, cualquier consumo se convierte así en insumo de una construcción de identidad y sentido, una búsqueda de una cultura propia y particular y en un ejercicio de revalorización, reubicación social y diferenciación.

Asimismo, Cevallos (2005) advierte que, de igual manera, la estética y los gustos del joven adquieren significados en los terrenos políticos en donde muchas veces asumen y sostienen una posición generalmente dirigida a dinamitar estructuras políticas de derecha, destructoras del medio ambiente, acaparadoras y procesos como la globalización. Desde este autor, toda la producción juvenil (sus atuendos, su música, los accesorios utilizados, sus lenguajes particulares) hace referencia a esta posición política y social sobre el mundo.

Entre las estéticas no es solamente valido mencionar elementos como la ropa, los accesorios o el lenguaje del que hacen uso los jóvenes, sino también la música se convierte en una fuente importante de sentido de las estéticas como una posición ética frente al mundo y a los demás. En un artículo académico desarrollado por Hormigos y Martin (2004), estos establecen una relación entre los procesos sociales y culturales acontecidos alrededor de la música denominada como popular (rock and roll, hip hop, pop) y la estructuración de subculturas particulares alrededor de estos referentes. Subculturas que dotaron de una diferenciación y particularidad a las diferentes expresiones juveniles acopladas a los géneros musicales y las iconografías que se recrearon a partir de los elementos constitutivos de un pensamiento de integración entre el consumo y la búsqueda particular de identidad. Sin embargo, como bien señalan los autores, estas juventudes no son diferentes entre sí por sus gustos y accesorios que utilizan, sino que amplifican sus campos de acción desde la música e integran a otros quienes también consideran en cierta forma, expulsados por la gran sociedad dominante. En particular, géneros como el rock, el reggae o el hip hop pretenden la inclusión de aquello que se percibe como excluido y construye juventud desde la cohesión más que desde la diferencia. 


\subsubsection{La juventud como grupo social que se autoconstruye}

Una de las imágenes que se han estado instaurando en el imaginario colectivo, es la del joven como ser autónomo e independiente: constructor de un "sí mismo" alejado de sus roles tradicionales, alejamiento que le es posible sólo a través de la creación de culturas propias, caracterizadas por una gran variedad y una cada vez más veloz modificación desde claves culturales anteriores. Esto lo transforma en destructor de aquello que lo objetiva, subjetiva e individualiza desde la cultura dominante y sus instituciones: familia, escuela, trabajo, mercado y Estado (Taguenca, 2009). No obstante, la perspectiva adoptada es útil en tanto, por un lado, da cuenta del concepto de juventud con base en sus diversas y características cambiantes, propias de contextos y tiempos delimitados y, por otro, niega su consideración como forma adulta, aunque sea en potencia o transición. Lo importante aquí es que el joven es joven porque se construye como tal en sus relaciones de oposición con las estructuras de las instituciones adultas y sus agentes, pero sobre todo a través de sus interacciones colaborativas con sus otros significativos, con los que construye un "sujeto liberado" en forma, pero atado en contenido a las particulares estructuras de lo juvenil construidas (Taguenca, 2009).

Independientemente de cuáles sean las formas que adquieran estas construcciones, lo importante en ellas es su negación de la cultura dominante, sea ésta cual fuere. Es esta negación la que está detrás de la rebeldía transformadora de lo dado que se intuye como liberación del "yo joven" a través de una confrontación que niega las raíces culturales de la élite para dar paso a la "nueva cultura". Empíricamente, esto se percibe como lo hizo Talcott Parsons (1949): "La cultura joven no es sólo, como ocurre en los aspectos curriculares de la educación formal, una cuestión de estatus de edad como tal, sino que también muestra signos de ser un producto de tensiones en la relación de los jóvenes y los adultos".

Siguiendo entonces lo comentado por Feixa (2006) y Taguenca (2009), la juventud debe luchar por su propia existencia desde sus contradicciones y diversidades culturales, que no son pocas, pero ante todo desde la oposición y negación de su contraparte: la cultura dominante, esto le resta, paradójicamente, libertad de acción, al aumentar los deberes 
normativos asociados a su participación en un grupo social juvenil, mismos que son fundamentales para la constitución de ésta y su permanencia unitaria. La juventud que se autoconstruye a sí misma en las interacciones con sus otros significativos, y en la negación de la cultura dominante, sus instituciones y agentes, termina convirtiéndose en una paradoja de sí misma, en tanto que en sus normas, valores y estéticas los jóvenes afirman su libertad, al tiempo que la niegan. La afirman porque sus formas son opuestas a las que la cultura dominante impone; la niegan porque sus contenidos son de "deber" que no admite excepción dentro de la propia comunidad juvenil en la cual se enmarca. Esta paradoja de la liberación identitaria de la juventud tiene aún otro alcance: con la eliminación de la contraparte, aunque tan sólo sea en un sentido figurado, quedarían truncados los caminos que conducen al mundo de la vida adulto, y también se vuelven más difíciles los cruces de puentes que permitan nuevas creaciones que transformen la cultura dominante, lo que abona la brecha generacional existente.

Al negar la cultura dominante la juventud encuentra su razón de ser, pero lo hace a costa de perder libertad y de eliminar las raíces culturales que la integrarán a la sociedad como adulto; cuando su identidad, aun incompleta, se complete a través de la formación. Pero el sometimiento a la cultura dominante tampoco es liberador ni transformador. Antes, bien al contrario, reduce la creatividad a lo existente admitido y la libertad a lo normativamente permitido. Llegados a este punto, al joven sólo le quedan dos caminos, ambos de dominación: el que lo conduce a autoconstruirse a través de sus interacciones con sus otros significativos, o el que lo conduce a autoconformarse como un ser incompleto que se encuentra en proceso formativo hacia lo adulto.

En el primer camino el joven queda sumido en un deber ser de comunidad que lo unifica en un mundo de la vida cerrado simbólica y materialmente, donde la cultura de la comunidad juvenil de adscripción se absolutiza para no ser colonizada por la cultura dominante, perdiendo de esta forma su capacidad creativa transformadora y liberadora. En el segundo camino el joven queda reducido a su condición de identidad adulta que aún no posee (Taguenca, 2009). Pareciera como si perdiendo su presente como joven, la juventud recuperara su futuro como adulto. Esto incluso después de todas las transformaciones socioculturales que caracterizaron la segunda mitad del siglo veinte, y que, con la finalización del siglo y la llegada del siglo XXI, todo volviera a un cauce 
cultural dominante del cual es posible entender que nunca debió haber sido abandonado. Al menos, esto es lo que parece decirnos Luigi Tomasi:

"A principios del siglo XXI, el término cultura juvenil ya no significa lo mismo que anteriormente. Ya no indica rebelión, abstención o rechazo del sistema social; ni siquiera significa experimentar directamente con los estilos de vida alternativos que se encuentran fuera de un sistema social dado. En lugar de ello, la cultura juvenil significa la capacidad intrínseca que tienen los jóvenes de definirse a sí mismos en sus conductas de valor en la sociedad a la cual pertenecen y su proyección hacia el futuro" (Tomasi, 1998, p. 6).

Esto último podría explicar mejor algunas intenciones de la producción cultural colombiana alrededor de la figura del joven durante los años 90, en tanto se buscaba mostrar como este hacia parte de la sociedad y como además estaban construyéndose a sí mismos, desde los espacios que se les eran permitidos a partir el adultocentrismo dominante en los canales de producción cultural, y a su futuro próximo como adultos.

Desde este autor, se entiende el concepto de juventud como un péndulo yendo de un lado hacia el otro, de cómo la cultura dominante se impone en su definición y de cómo las distintas culturas juveniles se autoconstruyen: en ninguno de los dos casos son posibles las construcciones duraderas de lo juvenil. Mientras en la primera forma la cultura dominante integra o desintegra a las culturas juveniles que quieren sustituirla, en el segundo, toda construcción cultural procedente de lo joven se realiza en conformidad con ella. A partir de aquí, es posible identificar los caminos posibles de entendimiento entre las dos posturas sobre la construcción de este concepto: por un lado, se reconoce el joven como el adulto que será en el marco social, sin embargo, mientras llega a ser, se patologiza su actuar y sus formas de ser y de crear en el entorno. Así, el joven puede ser entendido como "un vago", "bueno para nada", "pandillero", "Degenerado" y otras expresiones que evocan la juventud como una etapa que no encaja en los esquemas socioculturales aceptados, suprimiendo así su valor frente a sus producciones. 
La cultura dominante elimina las formas juveniles no admitidas. Sin embargo, las expresiones que provienen de aquélla y que invaden lo joven no sólo son admitidas, sino que incluso son promovidas. De esta manera, esta representación del joven, acordes con la identidad y el deseo de convertirse en un adulto "sano" y "adaptado" a la sociedad, sea considerada como la imagen de una "juventud ideal" a la que deben adherirse todos los jóvenes.

Desde esta tensión es posible reconocer dos caminos de ser joven: Una en sintonía con sus propias necesidades y sus caminos posibles de construcción, pero en posibilidad de conflicto con la cultura dominante, mientras la otra se muestra más en sintonía con el ser adulto, con la identificación desde la imitación de lo adulto y, por ende, más aceptado en la producción cultural y social.

En la medida en que ambos -jóvenes y adultos- se encuentren separados por situaciones, imaginarios, pensamientos, valores, normas, reglas, códigos, conductas esperadas y estéticas distintas, y en la medida en que éstas sean construidas por el joven y sus otros significativos, será posible realizar distinciones que den sentido a lo que entendemos por juventud. En este sentido, teóricamente debe ser posible establecer diferencias entre el "mundo de la vida adulto" y el "mundo de la vida del joven", por lo menos en cuanto a los procesos, relaciones y permutaciones en los ámbitos de la reproducción cultural, la integración social y la socialización, y en las relaciones estructurales entre ellos (Taguenca, 2009). Esto puede ser entendido y reproducido en lo que se pone en juego en la dinámica social entre los grupos de jóvenes y la manera en que estos se diferencian con los grupos de adultos que están alrededor de ellos.

En un entorno ficcional, es posible entonces rastrear la manera en que se ha venido construyendo la juventud desde estas diferenciaciones entre unos y otros a partir de aquello que realizan, sus estéticas, sus valores, sus maneras de solucionar problemas, el lenguaje que utilizan y algunas otras señas que establezcan diferencias entre ellos.

El joven que se reproduce desde lo ya dado tiene suficientes motivaciones para actuar de conformidad con las normas existentes, y posee la capacidad para interactuar con los adultos y con sus otros significativos. Los jóvenes que no atienden a la reproducción en 
este ámbito rompen con las tradiciones y pierden la motivación de actuar conforme a las normas que les vienen dadas que los separan de la posibilidad de definir conjuntamente las situaciones que dentro de la experiencia vital deben compartir con los adultos y con los jóvenes que sí atienden a esta reproducción. Esto confronta a los jóvenes que buscan una definición de su propia cohorte con sus propias expresiones, rasgos y mecanismos de reproducción social, solos, aislados, estigmatizados y confrontados con los otros que no comparten su visión del mundo. Como se ha mencionado, se patologiza y se apartan estos jóvenes de la cotidianidad de lo social y lo cultural.

En este encuentro, en esta lucha entre la juventud que se autoconstruye y la que reproduce lo ya existente, es donde surge la variablidad en las identidades juveniles que se hacen múltiple en sus manifestaciones y formas de expresarse, pero que finalmente encuentra un espacio común que le da identidad propia a una generación biológica y social, q viene dado desde quién construye. En este sentido, remitir los estilos de vida juveniles que aceptan la reproducción de lo adulto de manera incuestionada, a otros que tengan una mixtura entre la aceptación y el rechazo, o incluso a los que tienen su forma de ser en el repudio mismo de lo adulto y de los otros jóvenes que aceptan o rechazan lo culturalmente dominante para ellos, $u$ otras culturas dominadas igual a las suyas, lo que puede entregar cuadros diversos de distintas juventudes.

Desde esta investigación, se pretenderá utilizar el concepto de condición de juventud como un constructo múltiple que encierra más un proceso que una cristalización de la juventud como un concepto inalienable y definido por unos límites comprensibles y medibles. Se entiende entonces, que es un constructo que toma sus múltiples acercamientos desde lo histórico, cultural, social y contextual, y que alimenta su condición de elementos tan diversos como sus elementos estéticos, su posición social frente a la comunidad que los rodea, el contexto espacio temporal que ocupan, las relaciones que establecen con los otros, además, de plantear si es rastreable esta configuración de lo joven desde el grupo o desde el contexto sociocultural recogido en la serie. 


\subsection{JUVENTUD Y MEDIOS}

En el año 2010, la Escuela de Animación Juvenil (Medellín) publicó un documento en su serie "Cuadernos de Animación Sociocultural" titulado Contexto y Condición de Juventud del psicólogo Manuel López García en donde el autor, en un amplio recorrido por diferentes escenarios y espacios, construye un discurso sobre los contextos en los cuales discurre la juventud, la condición de juventud desde sus conceptos, sus orígenes y sus representaciones y finalmente, la manera en que las practicas juveniles y diferentes fenómenos emergentes asociados a la juventud pueden ser utilizadas como medios para la transformación social. En este documento, López reconoce que en nuestro país la televisión, en tanto medio masivo cultural, ha forjado identidades y representaciones alrededor de la figura del joven como construcción social. Por tanto, la revisión de la relación entre Juventud y la televisión como medio masivo de comunicación se visibiliza como uno de los principales retos académicos a abordar para las ciencias sociales y comunicativas modernas, en tanto puede brindar herramientas de carácter académico e investigativo que apunten hacia el mejoramiento de las producciones en nuestros medios audiovisuales que faciliten los procesos de comprensión y construyan bases más sólidas para el encuentro entre grupos intergeneracionales.

En principio y de manera general, se puede entender el papel de los medios con relación a los jóvenes en dos sentidos, por una parte como los jóvenes utilizan la televisión cómo un mecanismo de reafirmación de conductas, comportamientos, opiniones e ideas frente a la realidad que lo circunda y de la cual hace parte, por otro lado, es posible visualizar la manera en que los contenidos y el manejo de las realidades que se presentan en los programas televisivos han estado influyendo en la construcción de lo que significa ser joven e incluso, las formas de ser joven en el mundo. Se configura, entonces, en dos sentidos los análisis del papel de la juventud en relación con los medios de comunicación, en tanto audiencia como en medio productor de material simbólico en la construcción de las condiciones particulares de juventud y la relación de la sociedad con estos.

Para revisar las relaciones entre la Juventud, los jóvenes y los medios, es importante diferenciar los diferentes aspectos, los cuales pueden ser objeto de análisis y de abordaje 
bien sea por esta investigación o por otras subsecuentes. Así, a continuación, se revisarán las características de los medios como configuradores de las identidades sociales y la imagen de la juventud en los medios, haciendo un particular énfasis en el recorrido que este grupo poblacional ha tenido en la televisión colombiana, como medio de comunicación masiva.

\subsubsection{Los medios, instrumentos que ayudan a configurar la realidad personal.}

El papel de los medios en la manera en que tanto jóvenes como adultos construyen la realidad circundante, aun cuando esta realidad es la que en muchas ocasiones influye en el desarrollo y la guionización de los contenidos que se reproducen a través de estos, es una de las temáticas en que la investigación sobre medios se ha venido centrando en años más recientes (INJUVE, 2015).

Los jóvenes no se ven a sí mismos y a los medios como independientes del resto del mundo, sino como parte de la sociedad en la que viven (Naval y Sádaba, 2005). Por ello, y aunque el discurso dominante por parte de los medios, sea afirmar a veces que ellos no pretenden influir en la vida de nadie, es innegable que lo hacen y especialmente en el caso de la juventud. La manera en que los jóvenes han estado asumiendo su condición en la sociedad contemporánea no está exenta de las mediaciones que propone MartinBarbero en la comprensión de los efectos del consumo de la televisión, en tanto en muchas ocasiones es posible visualizar las maneras de vestir, comunicarse, asumir posiciones frente a la realidad y las relaciones interpersonales e intercomunicativas que establecen con los diferentes estamentos de la sociedad, desde aquello que se transmite desde el medio y lo que se puede encontrar en la cotidianidad.

Los medios de comunicación de masas, se han convertido en un importante agente de socialización de niños, jóvenes y adultos, una de cuyas características fundamentales es que permiten la comunicación, simultánea o no, con un elevadísimo número de personas en cualquier lugar del mundo. Como señala Guy Rocher (1989, p. 158) estos medios "sugieren, proponen y transcriben modelos, valores e ideales susceptibles de imponerse 
con tanta mayor fuerza y persuasión cuanto que se presentan en un contexto dramático o emotivo que contribuye a inhibir el juicio crítico". O como expresa de modo más rotundo Margarita Rivière (2003, p.41): "Los medios, en mi opinión ya no informan o, si lo hacen, ese objetivo resulta secundario. Los medios, aunque no quieran reconocerlo porque seguramente no tienen tiempo de reflexionar, educan. Ésa es su misión: la educación permanente de las personas, mediante la creación de preferencias, de valores, de hábitos culturales, de mitos y anti-mitos, de costumbres". A partir de esta concepción, en la medida en que los individuos tengan acceso a los contenidos propuestos por los programas de televisión, estarán confrontados a un proceso educativo en donde se moldearan sus actitudes, creencias, comportamientos y maneras de relacionarse consigo mismo y con el mundo que lo rodea, por tanto, la interacción entre los jóvenes y los contenidos presentes en los productos audiovisuales puede ser considerada, desde las definiciones entregadas por Aparici (2010), como un proceso educomunicativo, lo que dota de un nuevo sentido al acercamiento e interpretación de los contenidos que desde este medio se han estado distribuyendo en los productos audiovisuales.

Los medios masivos de comunicación pertenecen a lo que Lazarfeld y Merton (1977) denominan medios o grupos de referencia, por oposición a los grupos de pertenencia como sería el caso de la familia, una iglesia, una pandilla o un partido político. Por lo tanto, los medios, dadas sus características y su poderosa red de influencias tienen entre sus características el ser agentes socializadores de referencia capaces de contrarrestar, complementar, potenciar o anular la influencia de los agentes socializadores de pertenencia como la familia. Tanto unos como otros, los de pertenencia y los de referencia cumplen funciones socializadoras muy importantes. En primer lugar, nos aportan una gran parte de la información con la que construimos la imagen de la realidad de acuerdo a la cual desplegamos nuestros comportamientos. En segundo lugar, proporcionan valores, normas, modelos, símbolos, etc., gracias a los cuales se producen los procesos de construcción personal y de integración y cohesión social. Por último, es a través de esos medios como el sujeto construye y desarrolla su identidad, es decir, la definición que puede dar a sí mismo y a los demás de lo que él es en cuanto persona individual y social a la vez. La identidad es una necesidad psíquica y social, ya que contribuye tanto a la madurez de la personalidad como a la cohesión social. Esta posición dentro de los grupos de referencia, convierten a los medios de comunicación en 
un objeto de estudio de interés para las ciencias sociales en tanto tiene capacidad explicativa frente a las dinámicas que se desarrollan en la sociedad y en las relaciones entre los individuos pertenecientes a ella, particularmente, esta investigación acude al concepto de la televisión como grupo de referencia en tanto asume que a partir de los contenidos propuestos, fue puesta en práctica una manera diferencial de ser joven en un contexto determinado.

Según lo comentado por Vera Vila (2005), la proliferación de medios de comunicación, la ampliación de la capacidad de influir en una mayor cantidad de personas y la manera en que se ha venido intensificando la influencia en el tiempo debido a la mayor exposición a los contenidos presentes en los medios, en sus más variados formatos y formas de representación simbólica, ha producido una pérdida del control de los significados simbólicos, por parte de los ámbitos tradicionales de socialización como son la familia, las iglesias, la escuela o los partidos políticos. Es decir, de su capacidad para decir lo que las cosas significan, cuál es su importancia y cómo hay que valorarlas. De esta manera, se convierte en un punto de referencia desde el cual las juventudes toman elementos para constituirse y relacionarse con el entorno que los rodea, incluso más allá de los grupos de referencia tradicionales, por lo que las juventudes toman nuevas formas, lenguajes y maneras de ser en el mundo.

En este punto sobresale la duda de si es cierta la influencia de los medios de comunicación sobre la realidad. Teniendo en cuenta que, si "cuantificar los mensajes ya es de por sí difícil, mucho más lo es medir la influencia de múltiples mensajes que en ocasiones presentan contenidos que a veces son contradictorios y opuestos" (Sánchez, 1997: p. 131). Un acercamiento al problema de la influencia de los medios es propuesta por DeFleur y Ball-Rokeach (1993) quienes clasifican los efectos de los medios en tres categorías: cognitivos, afectivos y conductuales; y con diversos grados de influencia según la duración de sus efectos: a corto, medio y largo plazo.

Los primeros estudios sobre la influencia de los medios de comunicación estaban dirigidos a estudiar el medio en sí. En cambio, la segunda generación de investigaciones se centró en la manera en que reaccionan los receptores. La llamada teoría hipodérmica 
(Wolf, 1991) partía del supuesto de que los mensajes de los medios actúan como estímulos que afectan directamente y de forma homogénea a todos los individuos. Ello presuponía la existencia de un público pasivo y manipulable. Esta manera de describir los efectos de los medios fue progresivamente abandonada en la década de los cuarenta y los cincuenta. Se llegó a la conclusión de que los mensajes de los medios no traspasan al individuo como una aguja hipodérmica, sino que los mismos son interpretados de manera diferente por cada persona. Así, la superación de la teoría hipodérmica supuso la división de los estudios en diferentes campos: el quién emite (estudio sociológico de los medios), el qué (análisis de contenido de los mensajes), el canal (aspectos técnicos), el quién descodifica (los públicos y las audiencias) y finalmente la identificación y valoración de los efectos. Hoy en día en lugar de los términos "manipulación” o persuasión”, tiende a utilizarse el más genérico de "influencias". Y en lugar de preguntar sólo qué es lo que hacen los medios a las personas, también se inquiere acerca de lo que hacen las personas con los medios (Aguaded, 2000).

La juventud como concepto es una representación cultural que comparten los miembros de una cultura, una cultura que en la actualidad está cada vez más globalizada, en la que las representaciones y los significados socialmente construidos comparten elementos cuyo origen son otros grupos sociales distantes en el espacio y aún en el tiempo. Esto significa que ni la juventud, ni la infancia, ni la adultez son absolutas y universales, sino relativas y contingentes en el tiempo histórico y en los espacios culturales. Es decir, son construcciones sociales que revisten diversas formas en los distintos contextos históricos, sociales y culturales (Buckingham, 2002).

El predominio actual de las imágenes y su aparente simplicidad ha hecho que los más jóvenes hayan podido acceder con facilidad a ámbitos de los que antes se mantenían alejados por los adultos, lo cual ha contribuido a diluir las fronteras que separan a los niños de los jóvenes y a éstos de los adultos. En cierta medida, como señala Buckingham (2002) los menores se han convertido en pequeños adultos que anticipan todas las conductas que cabe esperar de ellos a edades más avanzadas y, por otro lado, los adultos nos hemos infantilizado en el sentido de que el ocio, la diversión, el sentido lúdico de la vida, lo sensorial ocupan un espacio que antes se suponía reservado a los menores. 
Los medios de comunicación, especialmente la televisión o Internet, son potentísimos difusores de recursos para la representación simbólica y la construcción de las identidades de los individuos y los grupos quienes se apropian de sus materiales para darles un sentido mediatizado por su cultura y su personalidad. Estos medios no están destruyendo ni a la infancia ni a la juventud, pero sin lugar a dudas son uno de los agentes que directamente a través de su socialización, e indirectamente a través de la socialización de los adultos están redefiniendo todas las etapas de la vida, también la juventud. Por tanto, se hace urgente e importante todos los ejercicios investigativos y reflexivos sobre el papel que han estado jugando los medios en la configuración de la juventud y la manera en que se reflejan las relaciones entre ellas en un espacio y tiempo determinado.

También occidente es absolutamente permeable a la influencia de otras religiones, tendencias musicales, modas en el vestir, en la alimentación, etc. Y, además, es posible que se esté asistiendo a una socialización global en valores, ideales y normas de acuerdo con las necesidades de un modelo económico consumista. El resultado son modelos de identidad híbridas y un debilitamiento generalizado de la coherencia de las culturas nacionales incluidas las más poderosas (Barker, 2003). Partiendo de esto, la búsqueda por una particular forma de ser joven en un mundo como el que se proyecta a través de la construcción ficcional también estaría transversalizada por las construcciones socioculturales de influencia de los cánones y los guiones propuestos por el entorno desde el cual se construye la ficción serializada. Una serie como "Cartas a Harrison", no solo pudo haber estado permeada por el contexto nacional y los referentes socioculturales próximos, sino que además podrían encontrarse elementos correspondientes a marcos referenciales mucho más macro de la cultura occidental.

Los medios de comunicación, -especialmente lo que se podría llamar "el sistema publicidad-moda" (Vera, 1995)- ejercen su influencia mayor en el tiempo libre, que es representado como un momento lúdico, de diversión y al que se le dedica más tiempo y recursos económicos que nunca. Es posible encontrar clasificaciones de los jóvenes que los identifican de acuerdo con la forma en la que consumen en su tiempo libre, con sus 
tendencias musicales, sus vestimentas, y también, pero derivado de todo lo anterior, con sus actitudes y valores. El modo en que interaccionan con los medios de comunicación y los valoran varía en función del grado en que se consideran integrados socialmente. (Vera, 1995). Así, es factible también interpretar que la representación de los jóvenes en la televisión juega un papel relevante en la identificación que estos mismos establecen para generar una conexión relevante entre ellos y la manera en que se diferencian de otros grupos, también relativos a una condición de juventud particular y a los adultos que los rodean.

\subsubsection{Imágenes juveniles en los medios}

Siguiendo lo analizado por Vera Vila (2005), la socialización de la juventud y la manera en que los medios de comunicación han estado influenciando este proceso tiene diferentes vertientes desde las cuales pueden ser analizadas. Una de ellas sería el papel que la juventud desempeña para los medios, en tanto que categoría conceptual, como público diana de sus mensajes, como parte de los grupos sociales representados en sus contenidos. A partir de aquí es susceptible de entenderse la búsqueda por la relación entre el Medio y la socialización juvenil desde 4 vertientes distintas: a) modelos de juventud representados en los medios así como sus características; b) número y características de las producciones que toman a la juventud como público consumidor de los programas, secciones, noticias, publicidad, etc.; c) análisis del concepto de juventud como ideal de vida feliz que facilita el consumo desinhibido de acuerdo con el modelo económico consumista; d) análisis de las representaciones, normas, valores, etc. que se vehiculan desde los medios hacia la juventud. Es en esta última vertiente señalada por Vera Vila, en donde encuentra su nicho primordial de desarrollo la presente investigación, en tanto asume que existe una representación particular y distintiva de una condición de juventud permeada por un contexto sociocultural e histórico que influyo sobre ella, y que fue vehiculada a través de la serie televisiva Cartas a Harrison para señalar una manera distinta de ser joven en nuestro país, bajo unos parámetros socioculturales que, a 20 años de su estreno en la televisión colombiana, ha sufrido ligeras variaciones, por lo que esta investigación aportaría al entendimiento de nuestra realidad particular con relación a nuestros jóvenes de hoy. 


\subsubsection{La imagen y la presencia de la juventud en los medios de comunicación.}

La representación de las culturas juveniles cumple en los medios la función de servir de modelos de referencia tanto para los niños, como para los adultos y para los propios jóvenes. Estos modelos acaban estereotipándose y siempre incluyen algunos rasgos que coinciden con la realidad; otros que van perdiendo vigencia y en los cuales ni siquiera los propios jóvenes se reconocen; y otros que, aunque pertenecen a una minoría de ellos, acaban siendo seguidos mayoritariamente durante un tiempo. Se da por lo tanto una dialogo entre los grupos juveniles tal y como son en realidad y la imagen que de ellos proyectan los medios.

La representación de la juventud en las series de televisión ha experimentado algunos cambios acordes con la evolución social, dando cabida a una variedad de modelos más rica y plural de la que podíamos encontrar hace sólo unos años. Si bien sigue predominando el prototipo de joven occidental de clase media, ahora está representado con matices que incluyen una mayor diversidad de situaciones típicas de su edad. Por supuesto sigue habiendo una juventud invisible, de la que apenas sí se da noticia en los informativos o en las propias series y que cuando aparecen suele ser de forma negativa o extremadamente simplista. Son los jóvenes trabajadores, los marginados, los inadaptados, o los que representan tendencias ideológicas muy minoritarias (Taguenca, 2009). De forma parecida, la imagen de la juventud de menos de 25 años que refleja la publicidad "enfatiza el disfrute del presente, la diversión, la amistad, la exaltación del grupo, el tiempo libre, el dinamismo, la vitalidad, la independencia, la rebeldía, la trasgresión, la naturalidad o la autenticidad. Por el contrario, superada esa edad, las claves serían otras, comenzando a destacarse la identificación con los adultos, la formación y la preparación para el futuro, la proyección y el éxito profesional, social y económico, la afirmación de la individualidad frente al grupo, la estabilidad afectiva, el bienestar y el cuidado de la salud, etc." (Megías, I. y Rodríguez, E., 2004: p. 150-151).

Una vez más hay que recordar que los medios de comunicación no se limitan a reflejar la realidad social, sino que la reinterpretan y proyectan imágenes simplificadas e 
interesadas de la misma que pugnan por definir el significado de ser joven (Reguillo, 2004). Como apostilla Paul Willis (2004: p. 130), los significados que son importantes para nosotros no nos los proporciona la familia, los sindicatos o la escuela, sino "aquellos que están haciendo negocio con nosotros", lo que nos obliga a tener que desarrollar las habilidades de deconstrucción mucho más allá de las propuestas educativas actuales, sumidas en parte en las mismas contradicciones consumistas. Contra esta capacidad de los medios -especialmente de la publicidad- para vulnerar los controles racionales y estimular las reacciones emocionales se proponen programas educativos de concienciación. Sin embargo, las investigaciones demuestran que los consumidores juveniles disponen de juicio crítico suficiente como para comprender el grado de engaño o ilusionismo que se esconde tras los reclamos del márketing, pero también reflejan que ello no garantiza en absoluto que vayan a dejar de utilizarse, ni que dejen de disfrutar viendo anuncios o consumiendo contenidos absolutamente superfluos (Buckingham, D., 2002).

\subsubsection{Construcción de perfiles de personajes en medios audiovisuales}

Una de los elementos de relevancia en la construcción de los personajes en los medios audiovisuales como el cine o la televisión, es la perfilación de los mismos. Este ejercicio de construcción, el cual realizan los guionistas y libretistas de las películas, series y programas de televisión, dota de un sentido particular a los elementos que se muestran en pantalla, toda vez que un personaje dotado de características personales y particulares, genera una dinámica diferenciadora a partir de ellas.

En la comprensión de quienes son los jóvenes en los contenidos de los medios, se hace importante reconocerlos desde su caracterización y perfilación particular, elementos que permitan brindar contexto y coherencia a las actitudes y valores que se pueden encontrar en las acciones que estos emprenden en el desarrollo ficcional, en su relación con los demás y con el entorno.

Para construir los insumos que permitan recolectar y organizar la información disponible en los contenidos de la serie, se requiere recabar las diferentes teorías que se han 
construido alrededor de este particular. De esta manera, han sido revisados diferentes autores que han elaborado propuestas para la construcción de personajes y la caracterización y perfilación de los mismos. Aquí se revisará principalmente tres autores, uno por tener una amplia influencia en la teorización y el estudio de la creación y estructuración de personajes como uno de los elementos más importantes para dotar de significado los contenidos de los productos audiovisuales (Seger), uno más en la línea de la construcción de personajes desde un enfoque hispanoamericano (Galán Fajardo) y otro, por darle un aterrizaje conceptual a la temática de la construcción y abordaje de personajes desde una perspectiva colombiana (Betancour).

En el año 1990, Linda Seger, consultora de guiones y doctora en artes, escribió el libro "Creating Unforgettable Characters" con la finalidad de brindar una estructura de creación de los personajes de la cual los guionistas podrían seguirse para remitir a un perfil particular acorde a las necesidades de estos en la elaboración de las historias a contar en las series ficcionales.

En la propuesta de Seger (1990), los personajes son entidades multidimensionales, polivalentes y ajustados a la realidad que se propone en el ambiente ficcional, por lo cual para su creación y elaboración se deben tener en cuenta una serie de principios de construcción siguiendo una estructura lógica como parte de un proceso que dota de sentido al personaje en el entorno ficcional. Los personajes que encontramos en la serie "Cartas a Harrison", tienen características que los hacen ricos en cuanto a elementos a definirlos y que funcionan en diferentes planos desde lo narrativo, por lo cual se convierten en interesantes sujetos de análisis sobre los que realizar el estudio de la representación de una determinada condición de juventud.

Como primer paso, Seger (1990) propone que se realice una investigación previa del contexto, para dotar de sentido las actuaciones de los personajes en el marco social e histórico en el cual se movilizan, además de las interacciones que les son permitidas desde su tipología y de los ambientes desde los cuales proviene. Es entonces, relevante para estudiar los personajes que encarnan una representación particular de un grupo social, tener en cuenta los antecedentes sobre los cuales se construyen las características de estos, así como en esta investigación se exploró el tema de juventud y 
su representación en los medios, como un antecedente de la representación mediática de la juventud en la serie objeto de estudio.

Igualmente, Seger (1990) considera las influencias culturales como parte del trasfondo de los personajes, junto con el contexto, el periodo histórico y el lugar en el que se encuentran. Todos estos aspectos, considerados en la contextualización del estudio de la representación mediática de la juventud, brindan un marco de comprensión del desarrollo del personaje en el ambiente ficcional y, por tanto, brinda oportunidad para reconstruir una representación particular del grupo social en el producto televisivo estudiado.

A partir de entender el trasfondo del personaje, se procura empezar a delimitar las características particulares del mismo empezando por su descripción física, el núcleo básico de personalidad, diversos niveles de expresión, que coinciden con los planteamientos de lo que se encuentra en el núcleo cognitivo de la representación planteado por Calonge (2006) (emociones, creencias y valores). Para Seger (1990), las emociones son expresiones que profundizan las características de personalidad de los personajes y que pueden ser categorizadas en 4 grandes grupos y cada uno de estos grupos, a su vez, incluir diversas emociones asociadas: "Furia encierra emociones en donde el personaje está enfadado, lleno de rabia, fastidiado, frustrado, irritado, y salido de sus casillas. Tristeza implica un personaje deprimido, sintiéndose desesperado, desalentado, autodestructivo, y melancólico. Satisfacción, incluye personajes alegres, felices y en éxtasis. Temor, indica personajes que demuestran miedo, terror, horror, y ansiedad." (Seger, 1990, p. 33).

Para Galán Fajardo (2007), quien realiza una recopilación de las diversas propuestas de construcción de personajes en entornos ficcionales, desde Egri (1946) hasta autores más recientes como Parker (2003), los personajes no se pueden desligar de la acción y el conflicto, en tanto conforman las tres aristas sobre las que se construye la narrativa de cualquier obra, incluyendo las obras audiovisuales, de tal manera el personaje no se puede explicar únicamente desde su perfil y su caracterización, sino que también es relevante tener en cuenta que hace el personaje y cuál es su importancia en la historia narrada, incluyendo sus motivaciones y el peso que toma en cada una de las tramas que se desarrollan en la obra audiovisual. Finalmente, concluye con una figura de los 
elementos y las categorías que se deben utilizar, basado en la propuesta de Egri, y que se retoma en gran medida en esta investigación:

\section{Dimensión física}

\begin{tabular}{|l|}
\hline Nombre del personaje \\
\hline Edad \\
\hline Aspecto físico \\
\hline Sexo \\
\hline Nacionalidad \\
\hline
\end{tabular}

Dimensión psicológica

\begin{tabular}{|l|}
\hline Tipo de personalidad \\
\hline Temperamento \\
\hline Objetivos/metas \\
\hline Conflictos internos \\
\hline
\end{tabular}

\section{Dimensión sociológica}

\begin{tabular}{|l|}
\hline Estabilidad en las relaciones \\
\hline Estado civil \\
\hline Ámbito familiar/no hijos \\
\hline Ámbito profesional/laboral \\
\hline Rango profesional \\
\hline Ámbito educacional \\
\hline Marco espacial \\
\hline Conflictos externos \\
\hline
\end{tabular}

Imagen 2. Propuesta de análisis de personajes. Egri adaptado por Galán Fajardo (2007).

Finalmente, se pasará a revisar la propuesta de Betancur (2007) para la tipificación de los personajes en tanto surge de la búsqueda de la caracterización de personajes en un medio audiovisual paralelo como lo es el cine colombiano. Para Betancur, retomando lo expuesto por Field (1994), la clasificación y caracterización de los personajes se realiza a partir de una categorización del rol que desempeñan los personajes en la obra audiovisual analizada. A continuación, se presentará un cuadro que muestra la categorización de los personajes a partir del rol que desempeñan en el producto audiovisual:

\begin{tabular}{|l|l|l|}
\hline \multicolumn{2}{|l|}{ TIPOS DE PERSONAJES } \\
\hline PRINCIPALES & SECUNDARIOS & FIGURANTES \\
\hline Protagonista & Confidente & \multirow{3}{*}{ De masa } \\
\cline { 2 - 2 } & Catalizador & \multirow{3}{*}{ Extra } \\
\hline Antagonista & Temático & \\
\cline { 2 - 2 } & Punto de vista & \\
\hline \multirow{3}{*}{ Interés romántico } & De contraste & \\
\cline { 2 - 2 } & De equilibrio & \\
\cline { 2 - 2 } & Divertido & \\
& & \\
\end{tabular}

Tabla 3. Tipología de personajes desde Betancur (2007). 
A partir del recorrido teórico e histórico que se ha venido delineando en este capítulo, en el próximo, se realizará la propuesta metodológica que acompañará esta investigación, en donde se hablará de las categorías de análisis a ser estudiadas, además de los mecanismos de los cuales se dispondrán para elaborar la recolección y análisis de los datos. 


\section{Capítulo 2. Marco Metodológico}

\subsection{Paradigma epistemológico}

Para Vasilachis (1997), hablar de paradigmas epistemológicos en investigación, es hacer referencia a posturas filosóficas íntimamente ligadas a la concepción de lo que es y debe ser la búsqueda del conocimiento científico, social e investigativo. Desde esta autora, citado por Martínez (2013), existen tres paradigmas que permiten el acercamiento a la realidad son: el materialista histórico, el positivista y el interpretativo, que emerge a partir del reconocimiento de la importancia de los aspectos simbólicos y significativos de la vida social y del lenguaje en la producción y reproducción del mundo (p. 2)

Desde el planteamiento inicial de la problemática a ser abordada en esta investigación, su objeto y los medios de los cuales se vale para recabar, estructurar y analizar la información, es posible visualizar una apuesta desde el paradigma epistemológico Hermenéutico interpretativo. Este paradigma busca acercarse a la realidad desde sus características y no centrarse en el objeto para indagar sus posibilidades "objetivas", se pretende descubrir y comprender los elementos que desde la construcción de aquello que se estudia hacen posible su realidad. Esta investigación busca abrir caminos de diálogos de saberes entre lo construido alrededor de la representación del joven en los medios de comunicación audiovisual.

A partir de clarificar el paradigma investigativo, es importante señalar que se utilizara una metodología de investigación cualitativa en tanto, aunque se recogen datos de manera numérica y porcentual, la intencionalidad del análisis de los mismos viene dado por las características cualitativas que se señalan a partir de estos. A pesar de la predominancia de la interpretación como medio para llegar a la realidad buscada a través de la 
investigación, los datos cuantitativos apoyan esta estructura y fortalecen los caminos que se utilizan para la comprensión de aquello a lo que se apunta desde los objetivos.

\subsection{Método}

Dentro del paradigma y la metodología, se encuentra el estudio de caso como método de elección, que utiliza como herramientas fundamentales para su abordaje la descripción, la interpretación y la evaluación y toma al caso como unidad de investigación que puede ser estudiado en sí mismo o en relación con otro. En este sentido, se convierte en el fenómeno o el acontecimiento significativo de una dinámica específica del hombre y de su grupo dentro de un marco sociocultural particular (Ramírez et. al, 2004:102). Para lo que aquí compete, el estudio de "cartas a Harrison" como un caso particular con características propias y enmarcadas en un contexto sociocultural particular (la producción televisiva colombiana de mediados de los años 90), posee características suficientes para ser abordado a partir de este método investigativo.

\subsection{Técnica investigativa: El Análisis de Contenido}

El análisis de las representaciones en producciones televisivas conlleva una comprensión teórica de estas imágenes enmarcadas en el formato en el cual se encuentran contenidas. Es necesaria, por tanto, el uso de una técnica de investigación que provea un análisis que tenga en cuenta la variedad de elementos presentes en la muestra analizada, puesto que cada uno de ellos imprime unas características particulares e implica un nivel de aparición de las distintas formas y estructuras que se corresponden con la condición de juventud que se pretende estudiar. Cabe considerar, a su vez, que el lenguaje televisivo se caracteriza por la multiplicidad de códigos y signos que se integran en su transcurrir enunciativo (imágenes, palabras, sonidos, músicas, textos verbales, entre otros).

En definitiva, para abordar un análisis de las representaciones de la condición de juventud en el medio audiovisual, se requiere de una técnica investigativa que, identificando para sí, las categorías y subcategorías de las cuales se componen las variables objeto de estudio de la presente investigación, pueda llegar a una comprensión de la realidad del objeto social estudiado. 
Desde una propuesta metodológica primordialmente cualitativa, a partir de la recolección de elementos que apunten hacia las variables en consideración, sus categorías y subcategorías emerge, como una alternativa viable para completar los objetivos propuestos en la presente investigación, el análisis de contenido "como investigación" (Casseti, Di chio, 1999) de la serie televisiva seleccionada, en tanto el objeto de estudio posee características que pueden ser aprehendidas a través de un análisis de los elementos que aparecen en pantalla.

Esta técnica investigativa, posee eficacia para analizar los contenidos mediáticos (Martin, 2008). En esta, el investigador necesita saber analizar el material simbólico o "cualitativo". Gran parte de la investigación moderna se realiza mediante tareas de clasificar, ordenar, cuantificar e interpretar los productos evidentes de la conducta de los individuos o de los grupos. El análisis es la actividad de convertir los "fenómenos simbólicos" registrados, en "datos científicos". Es tarea del análisis cualitativo el poder describir los elementos de ciertas conductas, registrarlos de forma ordenada, clasificarlos o categorizarlos, determinar su frecuencia cuantitativa e interrelaciones.

Muchas de las técnicas usadas en los medios tienen como objeto producir material simbólico para registrarlo y analizarlo adecuadamente. Dicho producto es material simbólico que revela algo que lo trasciende. Cuando el investigador ha logrado un conjunto de materiales cualitativos, procedentes de registros de elementos establecidos, deberá clasificar el contenido en categorías apropiadas para describirlo de forma ordenada y metódica. El proceso de clasificación es denominado análisis de contenido o codificación.

Para Berelson (Citado por Casetti y Di Chio, 1999), el análisis de contenido se define como una técnica de investigación cuya finalidad es la descripción objetiva, sistemática y cuantitativa del contenido manifiesto de la comunicación o de cualquier otra manifestación de la conducta. En una revisión posterior de esta definición, Casetti y Di Chio (1999), consideran que el análisis de contenido, más allá de entregar una descripción exacta de un objeto de estudio, brinda elementos que permiten acercarse a su realidad y los apartes que lo constituyen, como si de una disección se tratase.

Berelson señala tres enfoques de análisis de materiales simbólicos: 
-El investigador se interesa por las características del propio contenido.

-Trata de extraer inferencias válidas a partir de la naturaleza del contenido, respecto de las características de quienes producen el contenido.

-Interpreta el contenido con la finalidad de revelar algo sobre la naturaleza de los oyentes a quienes se dirige.

Acorde a la intencionalidad y objetivos que posee esta investigación, se puede entender que el primero de los enfoques propuestos por Berelson en el análisis del material simbólico es el que más se ajusta a la realidad que pretende abordar este documento, en tanto no busca llegar a conocer la intencionalidad de los autores, ni tampoco interpretar la naturaleza de la audiencia, sino llegar a extraer la representación de la condición de juventud a partir de los contenidos mismos del documento audiovisual.

El análisis de contenido buscará enfocarse en tres categorías: La construcción de la propuesta estética, la construcción de un perfil de caracterización de la juventud y la representación de esta condición de juventud. Cada una de estas categorías serán analizadas, a través del acercamiento a las siguientes subcategorías: la moda, música, lenguaje utilizado, conflictos y resolución, psicología de los personajes, sus elementos socioeconómicos y fisiológicos, finalmente, los valores y las creencias como componentes cognitivos de la representación mediática. En el siguiente diagrama es posible comprender de una manera visual las categorías y subcategorías de las que se compone el proceso de análisis de contenido propuesto en la presente investigación:
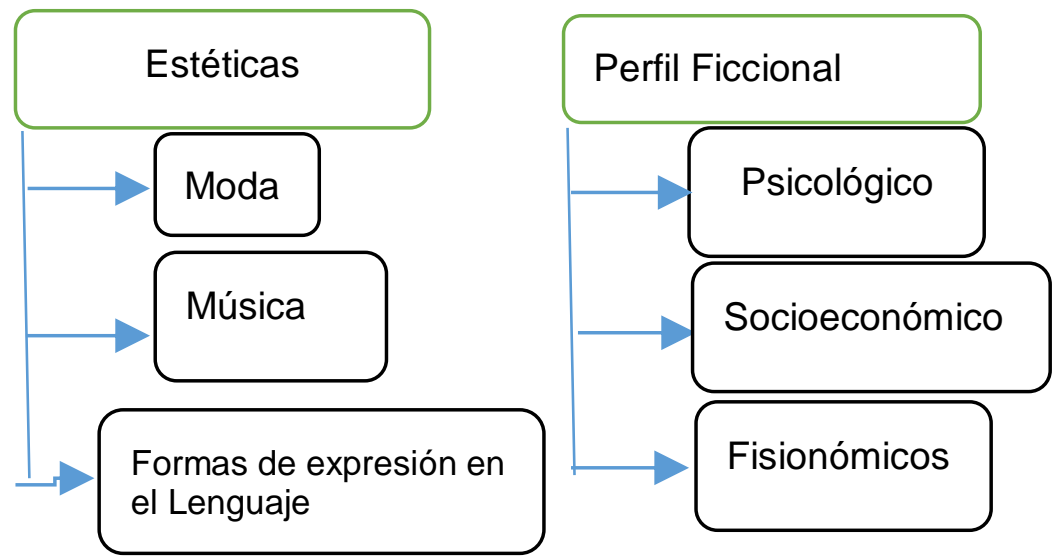

Dimensión cognitiva de la Representación

Imagen 3. Categorías Inductivas a explorar en la investigación.

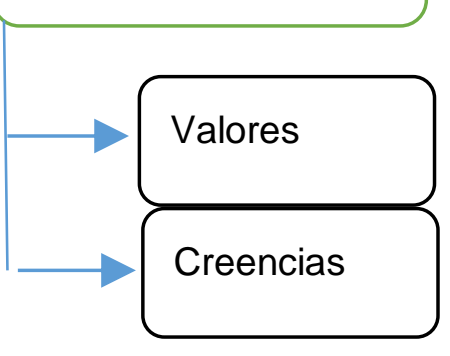




\subsubsection{Fases del Análisis de Contenido}

Como todo método de investigación, el análisis de contenido se estructura en una serie de fases. Debe igualmente establecer un perfil metodológico apropiado y un diseño de investigación eliminando los sesgos que se pueden suceder en las producciones científicas (Kientz, 1974, Krippendorff, 1990, 2013, Igartua, 2006, Casetti, di Chio, 1999). Para tal labor y apoyados en las teorías presentadas, se presenta el siguiente el diseño metodológico aplicado al análisis de contenido de esta investigación.

Paso 1. Definición y conceptualización de las categorías

Al tratarse de un trabajo de análisis de contenido, como en cualquier área de estudio de naturaleza empírica, el proceso de definición conceptual y operacionalización de las categorías está entre los pasos más importantes del proceso de investigación (Igartua, 2006; Bardin, 2011). Por lo tanto, es significativo que el investigador adopte una definición terminológica precisa de las unidades de la comunicación discursiva a analizar (Filho, 2004; Bakhtin, 2006)

Para la construcción de las categorías concernientes al presente trabajo investigativo, estas se construyen desde las aportaciones teóricas recogidas en el marco teórico de esta investigación, teniendo en cuenta las aportaciones de Taguenca (2009), Urcola (2003), Margulis y Urresti (1998), sobre la condición de juventud y la construcción del sentido de esta categoría frente a los desarrollos de la condición de lo adulto como categoría regulatoria en el marco social actual. En la construcción de la categoría "Representación Mediática" se tuvieron en cuenta las propuestas de Calonge (2006) y Tablante (2011), particularmente aquellas que remiten directamente a los contenidos y se expresan en el nivel cognitivo. Se consideraron las propuestas de Seger (1990), Galán Fajardo (2006) y LaCalle (2014) en cuanto a la construcción y análisis de personajes, estereotipos y tramas en los personajes de los programas de ficción serializada.

Paso 2. Selección de los capítulos de muestra

Para cumplir con el objetivo expuesto en esta investigación se realizara una muestra entre los 33 capítulos que componen la serie Cartas a Harrison, seleccionándolos por los siguientes criterios de elección: la presencia de los mismos ocho protagonistas; el 
escenario habitual, regular y constante durante todos los capítulos de la muestra (el barrio ficcional); la representación de una juventud con arraigo en las tramas barriales subyacentes y la presencia de elementos relacionados con la presentación y resolución de conflictos inter e intrageneracionales que se establecen entre los mismos jóvenes y frente a otros personajes que representan lo adulto.

A partir de la revisión de estos requisitos, se realizará análisis de contenido a 5 capítulos, contando el capítulo inicial, en donde se puedan rastrear las diferentes expresiones planteadas en el marco teórico-metodológico.

Los capítulos seleccionados son: (1) Despedida de Harrison, (2) Radio Lora 1, (3) Radio Lora 2, (4) Mahatma Randhi, (5) El TV Cable.

Paso 3. Elaboración de las fichas para codificación de la información

A partir de la definición de categorías y subcategorías, realizado durante el primer punto de la propuesta metodológica, se procede a construir una serie de fichas que permitan, entre otros objetivos, realizar una descripción general y contextual de la serie televisiva objeto de estudio; establecer una caracterización inicial de los capítulos que serán seleccionados como muestra para la investigación, la cual contiene elementos como los personajes que en ellos aparecen, la temática central que aborda el capítulo, el Director del capítulo, el tiempo de metraje del mismo y la sinopsis general del capítulo trasmitido; definir la construcción presente de los personajes pertenecientes a la obra audiovisual, de tal manera que recojan elementos estéticos y los perfiles de los mismos; finalmente, establecer la participación de cada tipo de personaje en cada uno de los tipos de las tramas, las actitudes presentadas y los valores asociados a estas actitudes.

Es válido hacer algunas precisiones sobre los datos que se van a recopilar en cada una de las matrices, de tal forma, que permitan extraer los elementos de análisis que se van a utilizar para desarrollar aquello que se busca en los objetivos específicos. Las precisiones se harán de manera sistemática teniendo en cuenta cada una de las tablas y matrices en las que se necesite hacer claridad sobre el tipo de información que se va a consignar en ellas. 
Tabla 4. Caracterización del capítulo

\begin{tabular}{|l|l|}
\hline Titulo & $\begin{array}{l}\text { (Se reproducirá el nombre del capítulo según lo encontrado en los } \\
\text { registros de producción de la serie) }\end{array}$ \\
\hline $\mathbf{N}^{\circ}$ de personajes & $\begin{array}{l}\text { (recuento del número de personajes que se presentan durante el } \\
\text { capítulo) }\end{array}$ \\
\hline $\begin{array}{l}\text { No de apariciones } \\
\text { (por personaje- \# } \\
\text { escenas) }\end{array}$ & (Conteo de apariciones de los personajes durante el capítulo) \\
\hline Tema & (Breve resumen de la temática que se aborda durante el capítulo) \\
\hline Director & $\begin{array}{l}\text { (Nombre del director del capítulo, según lo encontrado en los registros de } \\
\text { producción de la serie) }\end{array}$ \\
\hline Tiempo & (Anotación del tiempo total de duración de metraje) \\
\hline Sinopsis & (Resumen oficial del capítulo) \\
\hline
\end{tabular}

Tabla 5. Ficha de análisis del Capítulo Ficha de análisis del Capitulo

Tema: (se realiza un resumen de la temática que se trató durante el capítulo)

\begin{tabular}{|l|} 
\\
\hline Estructura \\
\end{tabular}

\begin{tabular}{|l|l|l|}
\hline Análisis & Relato & $\begin{array}{l}\text { Situaciones } \\
\text { o funciones } \\
\text { Textual }\end{array}$
\end{tabular}

Dominio de validez: (Alcance del contenido del capítulo en referencia a los niveles a los que se accede desde ellos, puede ser local, regional, nacional o internacional)

Carácter: (la producción fue realizada por medios públicos o privados)

\begin{tabular}{|c|c|}
\hline \multirow[t]{2}{*}{ Externa } & $\begin{array}{l}\text { Ubicación Horaria: (horario original en que fue transmitida la } \\
\text { serie) }\end{array}$ \\
\hline & $\begin{array}{l}\text { Modo de emisión: (periodicidad de la emisión de los } \\
\text { contenidos) }\end{array}$ \\
\hline \multirow{5}{*}{$\begin{array}{l}\text { Situaciones } \\
\text { o funciones } \\
\text { narrativas }\end{array}$} & $\begin{array}{l}\text { Situación inicial: (se hace una descripción del punto de } \\
\text { partida en la que inicia el capítulo) }\end{array}$ \\
\hline & $\begin{array}{l}\text { Puesta en escena: (Se establecen cuáles son las tramas y/o } \\
\text { las subtramas que se van a atender durante el relato) }\end{array}$ \\
\hline & $\begin{array}{l}\text { Complicación o punto de quiebre: (Se describen cuáles son } \\
\text { los elementos que introducen giros en la trama principal y } \\
\text { que podrían afectar las subtramas del mismo) }\end{array}$ \\
\hline & $\begin{array}{l}\text { Resolución: (se describe la manera en que se brinda una } \\
\text { salida a las dificultades que se plantean durante el capítulo) }\end{array}$ \\
\hline & Situación Final: (como finaliza el capítulo) \\
\hline \multirow[t]{2}{*}{ Personajes } & $\begin{array}{l}\text { Recurrencia: (organización de los personajes, según el } \\
\text { número de apariciones que tienen en el capítulo) }\end{array}$ \\
\hline & $\begin{array}{l}\text { Roles presentes: (Se clasifican los roles de los personajes } \\
\text { presentes en el capítulo, siguiendo la propuesta de } \\
\text { Betancur (2007) de la tipología de personajes: Protagonista, } \\
\text { Antagonista, Interés romántico, Confidente, Catalizador, } \\
\text { Temático, De masa, Punto de vista, De contraste, De } \\
\text { equilibrio, Divertido.) }\end{array}$ \\
\hline \multirow[t]{2}{*}{ Ambientes } & $\begin{array}{l}\text { Musicalización y Efectos sonoros: (se describe, } \\
\text { principalmente, que tipo de apoyo musical se brinda durante } \\
\text { el capítulo) }\end{array}$ \\
\hline & $\begin{array}{l}\text { Manejo de colores: (se describe el manejo de los colores en } \\
\text { los capítulos, en particular, si este altera de alguna forma la }\end{array}$ \\
\hline
\end{tabular}




\begin{tabular}{|l|l|l|l|}
\hline & & \begin{tabular}{l} 
narrativa del capítulo) \\
\cline { 3 - 3 }
\end{tabular} & $\begin{array}{l}\text { Espacios utilizados: (escenarios en los que transcurren las } \\
\text { tramas del capítulo) }\end{array}$ \\
\cline { 2 - 3 } & Historia & Trama & $\begin{array}{l}\text { Organización Temporal: (La trama es presentada de } \\
\text { manera secuencial o se realizan saltos en la temporalidad } \\
\text { de la misma) }\end{array}$ \\
\hline
\end{tabular}

Tabla 6. Análisis de personajes (por relevancia en el capítulo)

\begin{tabular}{|c|c|c|c|}
\hline \multirow{23}{*}{$\begin{array}{l}\text { PSICOLOGÍA DEL } \\
\text { PERSONAJE }\end{array}$} & \multirow{11}{*}{$\begin{array}{l}\text { ROL DEL } \\
\text { PERSONAJE }\end{array}$} & \multirow[t]{3}{*}{ Principal } & Protagonista \\
\hline & & & Antagonista \\
\hline & & & De interés romántico \\
\hline & & \multirow[t]{8}{*}{ Secundario } & Confidente \\
\hline & & & Catalizador \\
\hline & & & De masa \\
\hline & & & Contraste \\
\hline & & & Gracioso \\
\hline & & & Temático \\
\hline & & & Punto de Vista \\
\hline & & & Equilibrio \\
\hline & \multirow{4}{*}{\multicolumn{2}{|c|}{ TEMPERAMENTO }} & Melancólico \\
\hline & & & Colérico \\
\hline & & & Sanguíneo \\
\hline & & & Flemático \\
\hline & \multirow[t]{8}{*}{ PERSONALIDAD } & \multirow[t]{4}{*}{ Introvertido(a) } & Sensitivo \\
\hline & & & Cerebral \\
\hline & & & Sentimental \\
\hline & & & Intuitivo \\
\hline & & \multirow[t]{4}{*}{ Extrovertido(a) } & Sensitivo \\
\hline & & & Cerebral \\
\hline & & & Sentimental \\
\hline & & & Intuitivo \\
\hline \multirow{8}{*}{$\begin{array}{l}\text { ELEMENTOS } \\
\text { SOCIOECONOMICOS }\end{array}$} & \multirow{3}{*}{\multicolumn{2}{|c|}{ NIVEL SOCIOECONOMICO }} & Alto \\
\hline & & & Medio \\
\hline & & & Bajo \\
\hline & \multicolumn{2}{|l|}{ PROFESIÓN } & (Se escribe el nombre) \\
\hline & \multirow{4}{*}{\multicolumn{2}{|c|}{ EDUCACIÓN }} & Primaria \\
\hline & & & Bachillerato \\
\hline & & & Universitario \\
\hline & & & Posgradual \\
\hline \multirow{5}{*}{$\begin{array}{l}\text { FISIOLOGÍA DEL } \\
\text { PERSONAJE }\end{array}$} & GÉNERO & \multicolumn{2}{|c|}{ Femenino / Masculino } \\
\hline & \multirow{4}{*}{$\begin{array}{l}\text { EXPRESIONES } \\
\text { VERBALES }\end{array}$} & \multirow{4}{*}{ LENGUAJE } & Popular \\
\hline & & & Vulgar \\
\hline & & & Estándar \\
\hline & & & Elevado \\
\hline
\end{tabular}




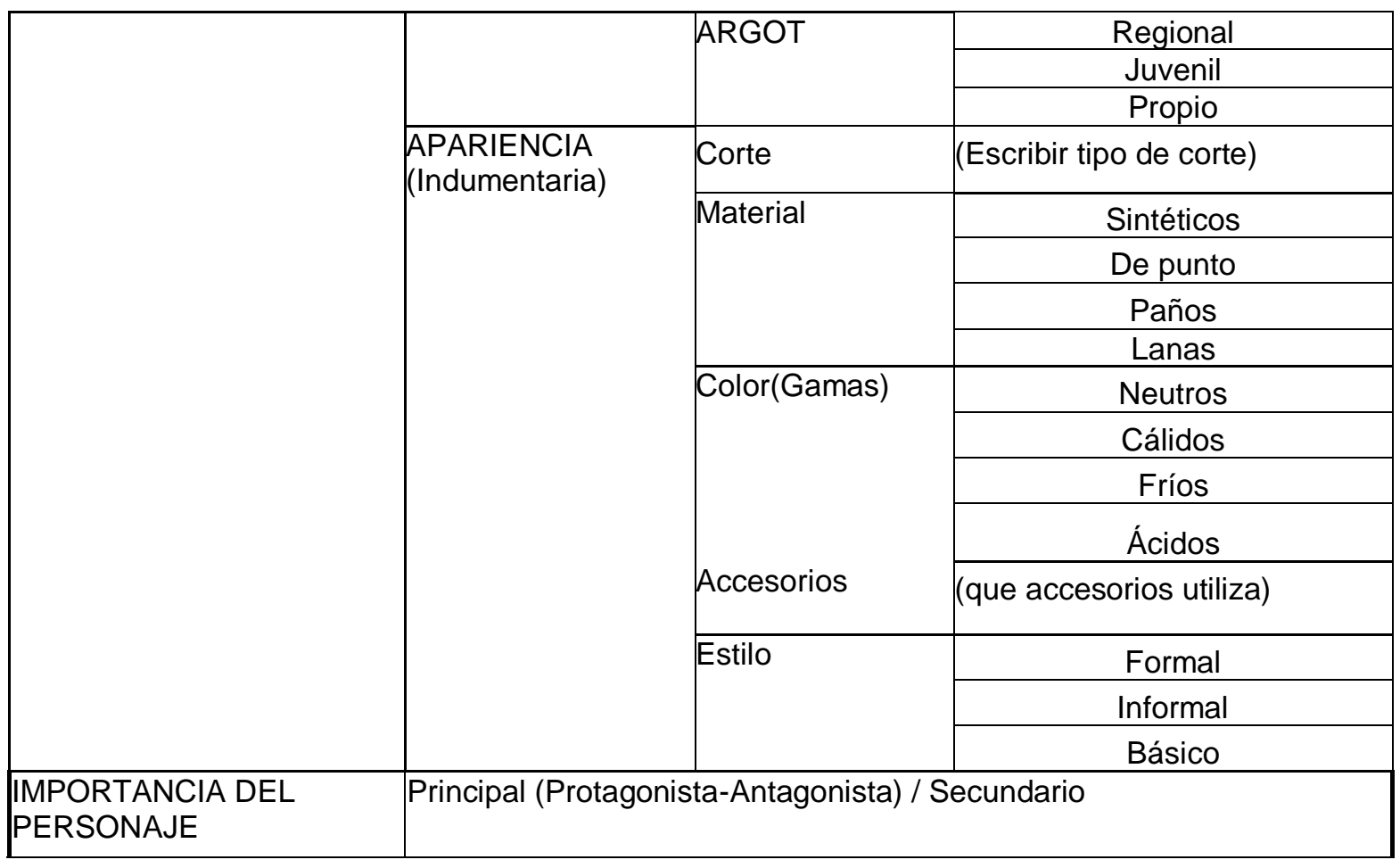


Tabla 7. Matriz Temas en orden de aparición en la narrativa del capítulo

\begin{tabular}{|l|l|l|}
\hline Tema en la trama & $\begin{array}{l}\text { Porcentaje de tiempo en } \\
\text { el capitulo }\end{array}$ & Porcentaje acumulado \\
\hline $\begin{array}{l}\text { (Según la segmentación de } \\
\text { los capítulos analizados) }\end{array}$ & $\begin{array}{l}\text { (Porcentaje de tiempo que } \\
\text { representa la trama en el } \\
\text { metraje) }\end{array}$ & $\begin{array}{l}\text { (Cantidad acumulada en } \\
\text { sumatoria con los temas } \\
\text { reseñados) }\end{array}$ \\
\hline
\end{tabular}

Para brindarle un mayor énfasis a los datos cualitativos que se sustraen de la revisión de los capítulos de la muestra y facilitar la lectura de los resultados, estas tablas con los porcentajes de las temáticas en la trama serán presentadas en los anexos a este documento.

Tabla 8. Matriz Temas / Tipo de Conflicto.

\begin{tabular}{|l|l|l|l|}
\hline \multirow{2}{*}{ Tema de la trama } & \multicolumn{2}{c|}{ Tipo de conflicto } \\
\cline { 2 - 4 } & Personal & Social & Contextual \\
\hline (Según la segmentación de los capítulos & (se clasifican & (se & (se \\
analizados) & los conflictos & clasifican & clasifican \\
& que & los & los \\
& involucren & conflictos & conflictos \\
& aspectos & que afecten & que afectan \\
& personales & la & el contexto \\
& de los & dimensión & próximo de \\
& personajes) & social de los & los \\
& & personajes) & personajes) \\
\hline
\end{tabular}

Tabla 9. Matriz Personajes / Conflictos / Valores.

\begin{tabular}{|c|c|c|c|c|c|}
\hline Personaje & $\begin{array}{l}\text { Importancia } \\
\text { del personaje } \\
\text { (Principal/Secu } \\
\text { ndario) }\end{array}$ & $\begin{array}{l}\text { Conflicto(s) } \\
\text { en el que } \\
\text { participa en } \\
\text { el capitulo }\end{array}$ & $\begin{array}{l}\text { Tipo de } \\
\text { Conflicto } \\
\text { (Personal/S } \\
\text { ocial/Contex } \\
\text { tual) }\end{array}$ & $\begin{array}{l}\text { Actitud frente } \\
\text { al conflicto }\end{array}$ & $\begin{array}{l}\text { Valores } \\
\text { asociados a } \\
\text { la actitud del } \\
\text { personaje }\end{array}$ \\
\hline $\begin{array}{l}\text { se } \\
\text { enumeran } \\
\text { los } \\
\text { personajes } \\
\text { de acuerdo } \\
\text { a su } \\
\text { prepondera } \\
\text { ncia en el }\end{array}$ & $\begin{array}{l}\text { (de acuerdo al } \\
\text { rol que } \\
\text { desempeña en } \\
\text { relación a la } \\
\text { mayor parte de } \\
\text { las temáticas } \\
\text { del capítulo) }\end{array}$ & $\begin{array}{l}\text { (acorde a la } \\
\text { numeración } \\
\text { de la matriz } \\
\text { anterior, se } \\
\text { consigna el } \\
\text { número de } \\
\text { los conflictos } \\
\text { en que }\end{array}$ & $\begin{array}{l}\text { (Se } \\
\text { relacionan } \\
\text { los tipos de } \\
\text { conflictos en } \\
\text { los que } \\
\text { participa el } \\
\text { personaje) }\end{array}$ & $\begin{array}{l}\text { (actitud asumida } \\
\text { ante el conflicto: } \\
\text { Nostalgia, } \\
\text { Apoyo, Rabia, } \\
\text { Desidia, } \\
\text { Proactividad, } \\
\text { Entusiasta, } \\
\text { Desconcierto) }\end{array}$ & $\begin{array}{l}\text { (Que valores } \\
\text { pueden ser } \\
\text { asociados a la } \\
\text { actitud } \\
\text { asumida por el } \\
\text { personaje, } \\
\text { siguiendo la } \\
\text { lista propuesta }\end{array}$ \\
\hline
\end{tabular}




\begin{tabular}{|l|l|l|l|l|l|}
\hline capítulo) & $\begin{array}{l}\text { participa el } \\
\text { personaje) }\end{array}$ & & & $\begin{array}{l}\text { por Schwartz, } \\
\text { ver anexo })\end{array}$ \\
\hline
\end{tabular}

Posterior a la recolección de la información disponible y pertinente utilizando las matrices aquí presentadas, es posible ir más allá de las categorías inicialmente construidas para avanzar en la interpretación de la información que nos conduzca a la resolución de los objetivos específicos propuestos en esta investigación. Para ello, a partir de lo hallado y codificado en estas tablas, se procederá a una interpretación de resultados desde las categorías que emerjan de este ejercicio metodológico, siguiendo los lineamientos propuestos por Cisterna (2005) para la elaboración de categorías emergentes, que permita ampliar las herramientas metodológicas de las que se dispone para extender el mapa de información necesaria y alcanzar los objetivos propuestos. Según esta propuesta, se debe establecer en primer lugar la información que se recogió durante el proceso y clasificarla, reconociendo los patrones comunes a ella, de tal manera que permita aglutinar los datos en conceptos que sirvan para construir las categorías comunes a ellos. Como menciona Cisterna (2005), las categorías en las investigaciones cualitativas pueden ser de dos órdenes distintos: apriorísticas, es decir, aquellas que se construyen desde la intencionalidad del investigador al iniciar la investigación y que buscan resolver elementos específicos en el proceso de construcción cualitativa de los resultados de la investigación, se definen desde el comienzo en tanto es lo que el investigador espera hallar en el recorrido de esta. Por otra parte, se encuentran las categorías emergentes, que surgen desde el levantamiento de referenciales significativos a partir de la propia indagación. Al hacer una investigación como la que aquí se propone, el uso de categorías emergentes se hace necesario, en tanto la información obtenida en ella es excesiva, muy rica en detalles y puede proporcionar elementos adicionales si logra ser estructurada más allá de las categorías organizadas apriorísticamente, al inicio de la investigación. Para este fin, se realizará un proceso inverso de reducción de datos y generación de categorías, partiendo de las descripciones de las situaciones recolectadas en las matrices y a partir de ahí, las subcategorías en las cuales pueden ser clasificadas y finalmente, las categorías emergentes en las que se integran tales subcategorías. 
Paso 4. Recolección de datos

Para la recolección de datos, se seguirá la propuesta de segmentación propuesta por Rick ledema (2001) en su documento "Analyzing Film and Television: a Social Semiotic Account of Hospital: an Unhealthy Business" en cuanto a los seis niveles de análisis del telefilm, en donde se utilizarán el tercer y el cuarto nivel. El tercer nivel "Escena" que, según lo planteado por ledema, remite a aquella que se define por la presencia de la cámara siguiendo la narrativa en un mismo tiempo-espacio, pero al mismo tiempo, está compuesta por más de una toma. El cuarto nivel, "Secuencia", Las secuencias comprenderán una serie de escenas contiguas que no están unidas sobre la base de la continuidad del espacio y el tiempo, sino sobre la base de una continuidad temática o lógica. Esto implica segmentar el capítulo en estas unidades, y sobre estas unidades temáticas y de tiempo, se aplicarán las fichas y las matrices planteadas para recolectar los datos.

Paso 5. Procesamiento de datos

Para culminar el análisis de contenido, una vez aplicado el instrumento de estudio, se procederá a establecer los perfiles tanto de las estéticas, las caracterizaciones de los personajes y los valores en ellos representados, que surjan a partir de la recolección de datos.

Para ello, se realizará una cuantificación de la frecuencia de aparición de las características en cada uno de los niveles de análisis y posteriormente, se cruzarán los datos para poder establecer inferencias a partir de los elementos recogidos.

En esta investigación se hace práctica del uso de las inferencias para lograr mejores resultados en el análisis de contenido, entendiendo que las inferencias son "los mecanismos lógicos empleados para relacionar los datos con su contexto" (Krippendorff, 1990: p. 45). Por lo tanto, las inferencias se realizarán sobre la base de los contenidos audiovisuales que se observaron en las secuencias de los capítulos seleccionados. Las fichas de análisis y las tres matrices elaboradas para esta investigación, buscaron combinar elementos y características propias de las imágenes con que se representó la condición de juventud en la serie "Cartas a Harrison". En tanto la serie ficcional lleva una secuencia y se corresponde con una lógica y un espacio narrativo común, la intencionalidad aquí se centra en lo construido de la representación específica desde las 
estéticas, la caracterización y la presencia de valores reconocibles en la presentación de la obra audiovisual.

\section{Capítulo 3. Presentación de Resultados}

Después de realizar la visualización de los capítulos, siguiendo el orden establecido y realizando la segmentación de cada uno de estos y de someterlos a un análisis del corpus seleccionado, que se constituyó en cinco de ellos seleccionados, divididos en 197 escenas estudiadas, puede adelantarse que hay una condición particular de juventud que se encuentra mediada por el uso del lenguaje, la estética y los valores que representan los diferentes personajes que se encuentran en la serie. Aunque el contexto compartido es el mismo, la manera en que cada uno de los personajes actúan y reaccionan frente a los conflictos planteados en la serie es distinta, por tanto, la condición de juventud expuesta en esta serie es heterogénea y a su vez, se enriquece por las diferencias que existen entre pares que comparten un contexto y una experiencia vital.

A continuación, se presentan las observaciones recogidas, capítulo a capítulo, en donde primero se realiza una caracterización de la unidad estudiada, seguidamente, un análisis de aquello planteado durante el episodio lo cual nos guiará en los planteamientos desarrollados durante la trama, los personajes, la ambientación del mismo y el desarrollo temporal de la historia.

Posteriormente, se adelanta un análisis individual de los personajes del capítulo, en este sentido, se seleccionaron los personajes con mayor peso en el desarrollo de la trama del capítulo puesto que, aunque los personajes que hacen parte del grupo de jóvenes son recurrentes en la serie, no en todos los capítulos cumplen una función narrativa importante para el desarrollo de los temas que se abordan desde la trama del capítulo. 
Para la elección de los personajes analizados por capítulo, se tuvo en cuenta la recurrencia de estos en las escenas del capítulo, el peso narrativo particular en las tramas desarrolladas y el rol que desempeña el personaje durante el capítulo. Aunque la mayoría de personajes analizados se corresponden con los jóvenes presentes en la serie, existen cuatro casos excepcionales en donde se analizan personajes adultos, por una parte, para establecer contrastes entre estos y los personajes de representación juvenil, y por otra, para revisar la manera en que se posicionan frente a las dinámicas de los jóvenes en la serie y el papel que estos juegan en la construcción de la representación particular de cada uno de estos. Vale la pena aclarar que, por la extensión de estos análisis individuales, estos elementos se referirán en los anexos de la investigación y aquí solo se reseñará el análisis global de los personajes en los cinco capítulos.

Finalmente, se revisan los temas y los conflictos que se manejan durante el capítulo y la relación que tienen los personajes con las temáticas y los conflictos planteados durante el capítulo.

A manera de cierre, se realiza una recopilación de elementos comunes a todos los capítulos que permitan orientar la posterior discusión a la luz de los elementos teóricos y conceptuales recogidos a través del desarrollo del presente trabajo de grado.

\subsection{ANALISIS POR CAPITULOS DE LA SERIE}

\section{CAPITULO 1 “DESPEDIDA DE HARRISON”}

\section{Tabla 10. Caracterización primer Capítulo.}

\begin{tabular}{|l|l|}
\hline Titulo & Despedida de Harrison \\
\hline $\mathbf{N}^{\circ}$ de personajes & 16 \\
\hline $\begin{array}{l}\mathbf{N}^{\circ} \text { de apariciones } \\
\text { (por personaje- \# } \\
\text { escenas) }\end{array}$ & $\begin{array}{l}\text { (En orden de aparición) Marisela (14), Albeiro (17), Lalo (12), Eric (20), } \\
\text { Nacho (12), Mireya (9), Randy (8), Nancy (8), Don Ernesto (1), } \\
\text { Harrison (1), Afranio (8), Abogado embargo (2), Mamá Albeiro/Eric (6), } \\
\text { Don Ignacio (1), Graciela (4), Julio (2), Vecinos (2), Jóvenes banda } \\
\text { musical (1). }\end{array}$ \\
\hline Tema & $\begin{array}{l}\text { Presentación inicial de los personajes y establecimiento de la dinámica } \\
\text { de la serie en referencia a los conflictos a darse a partir de la relación } \\
\text { de estos y el contexto. }\end{array}$ \\
\hline Director & Harold Trompetero \\
\hline
\end{tabular}




\begin{tabular}{|l|l|}
\hline Tiempo & 45 minutos 30 segundos \\
\hline Sinopsis & A partir de la Despedida de Harrison hacia Estados Unidos, los \\
& muchachos tienen que enfrentar su primer gran reto sin el liderazgo de \\
& Harrison, al buscar la forma de evitar el desalojo del apartamento de \\
& Nancy, se genera un conflicto entre Albeiro y Eric por la forma de \\
& recolectar el dinero para solucionar la problemática. \\
\hline
\end{tabular}

Tabla 11. Ficha análisis del primer capítulo.

\begin{tabular}{|c|c|c|c|}
\hline \multicolumn{4}{|c|}{ Ficha de análisis del Capitulo } \\
\hline \multirow{3}{*}{\multicolumn{2}{|c|}{$\begin{array}{l}\text { Tema: Presentación inicial de } \\
\text { los personajes y } \\
\text { establecimiento de la } \\
\text { dinámica de la serie en } \\
\text { referencia a los conflictos a } \\
\text { darse a partir de la relación } \\
\text { de estos y el contexto. } \\
\text { Estructura }\end{array}$}} & \multicolumn{2}{|c|}{ Dominio de validez: Local } \\
\hline & & \multicolumn{2}{|c|}{ Carácter: Publico } \\
\hline & & \multirow[t]{2}{*}{ Externa } & Ubicación Horaria: Nocturna \\
\hline \multicolumn{2}{|c|}{ Estructura } & & $\begin{array}{l}\text { Modo de emisión: Frecuencia de emisión } \\
\text { semanal }\end{array}$ \\
\hline \multirow[t]{8}{*}{$\begin{array}{l}\text { Análisis } \\
\text { Textual }\end{array}$} & \multirow[t]{8}{*}{ Relato } & \multirow[t]{5}{*}{$\begin{array}{l}\text { Situaciones o } \\
\text { funciones } \\
\text { narrativas }\end{array}$} & $\begin{array}{l}\text { Situación inicial: Los jóvenes son introducidos en } \\
\text { la historia, en la despedida de Harrison en el } \\
\text { aeropuerto. }\end{array}$ \\
\hline & & & $\begin{array}{l}\text { Puesta en escena: Posible desalojo de Nancy de } \\
\text { la casa en donde vive. }\end{array}$ \\
\hline & & & $\begin{array}{l}\text { Complicación o punto de quiebre: Eric y Albeiro, } \\
\text { en su afán de despuntar como nuevo líder del } \\
\text { grupo, se disputan por cual puede ser la mejor } \\
\text { actividad que se puede realizar para recoger } \\
\text { fondos para evitar el desalojo. }\end{array}$ \\
\hline & & & $\begin{array}{l}\text { Resolución: Marisela decide aunar ambos } \\
\text { esfuerzos en uno solo y sacar adelante la } \\
\text { recolección de fondos. }\end{array}$ \\
\hline & & & $\begin{array}{l}\text { Situación Final: Se logra recolectar los fondos, sin } \\
\text { embargo, Don Afranio lleva a la policía quien } \\
\text { termina la actividad y se lleva a todos los } \\
\text { muchachos a la estación por vender licor a } \\
\text { menores de edad. }\end{array}$ \\
\hline & & \multirow[t]{2}{*}{ Personajes } & $\begin{array}{l}\text { Recurrencia: (1) Eric, (2) Albeiro, (3) Marisela, (4) } \\
\text { Nancy, (5) Nacho, (6) Lalo, (7) Afranio. }\end{array}$ \\
\hline & & & $\begin{array}{l}\text { Roles presentes: Protagonista, Antagonista, de } \\
\text { interés romántico, catalizador, de contraste. }\end{array}$ \\
\hline & & Ambientes & $\begin{array}{l}\text { Musicalización y Efectos sonoros: Se utilizan } \\
\text { apartes y pistas completas de canciones de rock } \\
\text { para musicalizar el capítulo. } \\
\text { Manejo de colores: Los colores utilizados durante } \\
\text { el capítulo se corresponden con la iluminación }\end{array}$ \\
\hline
\end{tabular}




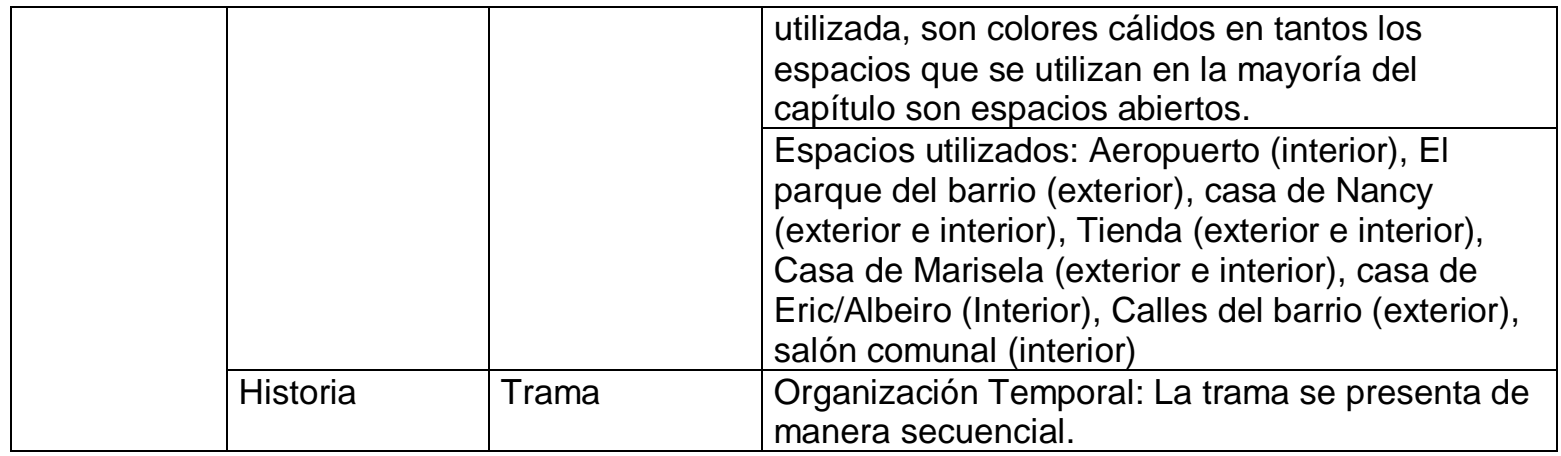

Durante este primer episodio, a partir de la Despedida y partida de Harrison hacia Estados Unidos, se nos realiza una introducción a los personajes que van a ser recurrentes durante la serie, los ocho jóvenes protagonistas de la historia en Cartas a Harrison (Marisela, Eric, Albeiro, Lalo, Mireya, Nancy, Nacho, Randy), que explica su nombre y narrativa desde las situaciones que cada uno de los jóvenes realizan de las vivencias que tienen en el barrio y entre ellos, a través de "cartas" enviadas a Harrison en los Estados Unidos. Este es el único episodio en que el inicio de la carta se da después de la primera secuencia, en donde los muchachos despiden a Harrison en el Aeropuerto, y la "carta" la envía Albeiro en donde relata lo acontecido con la casa de Nancy y como resolvieron la situación. Esta estrategia narrativa se mantiene durante toda la serie, en ocasiones, variando el autor de cada una de las cartas. La relación con el resto de los habitantes del barrio no se visualiza muy delineada durante este primer episodio, sin embargo, si se establece el personaje de Afranio (padre de Marisela) como el antagonista de los jóvenes y con el cual mantienen una tensa relación que, en el transcurso de este primer episodio, intenta ser mediada por Marisela. La musicalización del episodio plantea una relación de la narrativa juvenil asociada con el Rock como vehículo para contar y visibilizar las historias que se narran en ella. El manejo de los colores y la utilización del espacio, nos muestran que esta es una juventud que se encuentra insertada en la cotidianidad del barrio y que no se resiste a ella, sino que, por el contrario, surge de esta para construir su narrativa particular. Únicamente, una sola de las escenas tiene un manejo de colores diferentes y una musicalización distinta, para resaltar el encuentro intergeneracional en el momento en que la mamá de Eric y Albeiro decide enseñarle a Lalo a bailar tango, para que este pueda bailar con Mireya y de esta manera impresionarla. Entonces, en este primer episodio, no solo la figura de Afranio, como antagónico y quien rechaza desde su actitud y su lenguaje a los jóvenes, sino la 
figura de la madre de Eric y Albeiro, quien aprueba, orienta y guía en sus apariciones a través del capítulo, muestran la relación y las tensiones que se generan en el encuentro de estos dos grupos generacionales.

Tabla 12. Matriz Temas / Tipo de Conflicto en el primer capítulo.

\begin{tabular}{|c|c|c|c|c|}
\hline & \multirow[t]{2}{*}{ Tema de la trama } & \multicolumn{3}{|c|}{ Tipo de conflicto } \\
\hline $\mathrm{N}^{\circ}$ & & Personal & Social & Contextual \\
\hline 1 & Despedida de Harrison & & & $\mathrm{x}$ \\
\hline 2 & Desalojo del apartamento de Nancy & & & $\mathrm{x}$ \\
\hline 3 & Referencias al pasado relacional de los jóvenes & $\mathrm{x}$ & & \\
\hline 4 & $\begin{array}{l}\text { Opciones de recolección de fondos para evitar el } \\
\text { lanzamiento definitivo }\end{array}$ & & $x$ & $x$ \\
\hline 5 & Triangulo Lalo/Mireya/Graciela & $\mathrm{x}$ & & \\
\hline
\end{tabular}

En la matriz anterior, se muestra la relación de las temáticas desarrolladas y la preponderancia que tienen estas en el desarrollo del capítulo, además de la clasificación de los conflictos relacionados en esas temáticas. Para este episodio, las diferentes alternativas que encarnan Eric y Albeiro en la búsqueda de opciones para recolectar los fondos necesarios para evitar el lanzamiento y embargo del apartamento de Nancy, es la temática de mayor peso y relevancia en la historia, a su vez, permite establecer la confrontación que existe entre los hermanos y la manera en que cada uno de estos visualiza a la comunidad que los rodea. Mientras Albeiro (y Marisela, quien está de acuerdo con el), considera realizar un baile e invitar a todos los mayores del barrio, en tanto entiende que estos pueden aportar una mayor cantidad de dinero, Eric piensa en realizar un concierto de rock, por lo que se concentra más en aglutinar a la población joven y demeritar las posibilidades que ofrecen los adultos, por lo que las posiciones encontradas entre los dos hermanos revelan dos posiciones diferentes que asumen los jóvenes frente a la relación con los adultos que los rodean y como los visualizan dentro del entramado de acciones que deben realizar para poder sacar adelante sus proyectos y proyecciones: por un lado, una juventud que acoge y se inserta en el entramado propuesto por los adultos sobre las dinámicas sociales permitidas y relevantes en el medio social, y por otro, una juventud que rechaza y busca construir sus propios códigos haciendo usufructo de aquello que el adulto ha construido, es decir, no lo niega directamente, pero si se convierte en un entramado utilitario para él. Los otros temas 
sirven para dar contexto a esta temática principal y mostrar cómo se han construido las relaciones y en qué punto se encuentran en el momento en que nos lleva la serie.

Tabla 13. Matriz Personajes / Conflictos / Valores en el primer capitulo

\begin{tabular}{|c|c|c|c|c|c|}
\hline Personaje & $\begin{array}{l}\text { Importancia del } \\
\text { personaje } \\
\text { (Principal/Prota } \\
\text { gónico/Secund } \\
\text { ario) }\end{array}$ & $\begin{array}{l}\text { Conflicto(s) } \\
\text { en el que } \\
\text { participa en } \\
\text { el capitulo }\end{array}$ & $\begin{array}{l}\text { Tipo de } \\
\text { Conflicto } \\
\text { (Personal/ } \\
\text { Social/Con } \\
\text { textual) }\end{array}$ & $\begin{array}{l}\text { Actitud } \\
\text { frente al } \\
\text { conflicto }\end{array}$ & $\begin{array}{l}\text { Valores } \\
\text { asociados a la } \\
\text { actitud del } \\
\text { personaje }\end{array}$ \\
\hline Eric & Principal & $1,2,3,4$ & P-S-C & $\begin{array}{l}\text { (1) Desidia, } \\
\text { (2) Proactivo, } \\
\text { (3) Nostalgia, } \\
\text { (4) Proactivo. }\end{array}$ & $\begin{array}{l}\text { Poder, Logro, } \\
\text { Hedonismo, } \\
\text { autodirección }\end{array}$ \\
\hline Albeiro & Principal & $1,2,3,4$ & P-S-C & $\begin{array}{l}\text { (1) Nostalgia, } \\
\text { (2) Asertiva, } \\
\text { (3) }\end{array}$ & $\begin{array}{l}\text { Universalismo, } \\
\text { Benevolencia, } \\
\text { Tradición, } \\
\text { Seguridad }\end{array}$ \\
\hline Marisela & Principal & $1,2,3,4$ & P-S-C & $\begin{array}{l}\text { (1) Pesar, (2) } \\
\text { Desconcierto, } \\
\text { (3) Nostalgia, } \\
\text { (4) }\end{array}$ & $\begin{array}{l}\text { Conformidad, } \\
\text { Benevolencia, } \\
\text { Tradición }\end{array}$ \\
\hline Nacho & Secundario & $1,2,3$ & P-C & $\begin{array}{l}\text { (1) Nostalgia, } \\
\text { (2), Apoyo, } \\
\text { (3) Proactivo }\end{array}$ & $\begin{array}{l}\text { Universalismo, } \\
\text { Conformidad, } \\
\text { Benevolencia }\end{array}$ \\
\hline Nancy & Secundario & $1,2,3,4$ & P-S-C & $\begin{array}{l}\text { (1) Nostalgia, } \\
\text { (2) Rabia, } \\
\text { (3), Desidia } \\
\text { (4) Proactiva }\end{array}$ & $\begin{array}{l}\text { Autodirección, } \\
\text { Universalismo }\end{array}$ \\
\hline Lalo & Secundario & $1,2,5$ & C-P & $\begin{array}{l}\text { (1) Neutral, } \\
\text { (2) Proactivo, } \\
\text { (5) } \\
\text { Entusiasta }\end{array}$ & $\begin{array}{l}\text { Universalismo, } \\
\text { Benevolencia }\end{array}$ \\
\hline Afranio & Antagónico & 2 & C & (2) Diligente & $\begin{array}{l}\text { Poder, Logro, } \\
\text { Hedonismo, } \\
\text { Autodirección, } \\
\text { Tradición. }\end{array}$ \\
\hline
\end{tabular}




\section{CAPITULO 2 "RADIO LORA"}

\section{Tabla 14. Caracterización segundo capitulo}

\begin{tabular}{|l|l|}
\hline Titulo & Radio Lora \\
\hline $\mathbf{N}^{\circ}$ de personajes & 16 \\
\hline $\begin{array}{l}\mathbf{N}^{\circ} \text { de apariciones } \\
\text { (por personaje- \# } \\
\text { escenas) }\end{array}$ & $\begin{array}{l}\text { (En orden de aparición) Marisela (20), Eric (24), Randy (9), Albeiro } \\
(17), \text { Lalo (21), Graciela (15), Afranio (14), Mireya (8), Nacho (7), } \\
\text { Nancy (9), Doña Tulia (8), Don Francisco (8), Mamá Eric/Albeiro (2), } \\
\text { Vecinos (5), Vendedor de pinturas (1), Mamá de Graciela (1) }\end{array}$ \\
\hline Tema & $\begin{array}{l}\text { Los muchachos deciden realizar transmisiones radiales en donde } \\
\text { denuncian diferentes problemáticas del barrio, en donde en todas se } \\
\text { encuentra involucrado Afranio. }\end{array}$ \\
\hline Director & Harold Trompetero \\
\hline Tiempo & $\begin{array}{l}\text { 44 minutos 48 segundos } \\
\text { Sinopsis }\end{array}$ \\
$\begin{array}{l}\text { Eric ve la oportunidad para empezar a apoderarse del lugar que } \\
\text { ocupaba Harrison, pero las dificultades no dejan de presentarse. }\end{array}$ \\
\hline
\end{tabular}

Tabla 15. Ficha de análisis del segundo capítulo

\begin{tabular}{|c|c|c|c|}
\hline \multicolumn{4}{|c|}{ Ficha de análisis del Capitulo } \\
\hline \multirow{3}{*}{\multicolumn{2}{|c|}{$\begin{array}{l}\text { Tema: Los muchachos } \\
\text { deciden realizar } \\
\text { transmisiones radiales en } \\
\text { donde denuncian diferentes } \\
\text { problemáticas del barrio, en } \\
\text { donde en todas se encuentra } \\
\text { involucrado Afranio. } \\
\text { Estructura }\end{array}$}} & \multicolumn{2}{|c|}{ Dominio de validez: Local } \\
\hline & & \multicolumn{2}{|c|}{ Carácter: Publico } \\
\hline & & \multirow[t]{2}{*}{ Externa } & Ubicación Horaria: Nocturna \\
\hline \multicolumn{2}{|c|}{ Estructura } & & $\begin{array}{l}\text { Modo de emisión: Frecuencia de emisión } \\
\text { semanal }\end{array}$ \\
\hline \multirow[t]{3}{*}{$\begin{array}{l}\text { Análisis } \\
\text { Textual }\end{array}$} & \multirow[t]{3}{*}{ Relato } & \multirow[t]{3}{*}{$\begin{array}{l}\text { Situaciones o } \\
\text { funciones } \\
\text { narrativas }\end{array}$} & $\begin{array}{l}\text { Situación inicial: Randy logra hacer funcionar la } \\
\text { emisora y Eric, junto con el resto del grupo, } \\
\text { deciden utilizar este espacio para acercarse a la } \\
\text { comunidad. }\end{array}$ \\
\hline & & & $\begin{array}{l}\text { Puesta en escena: Se empiezan a generar las } \\
\text { transmisiones con el programa direccionado por } \\
\text { Eric, en donde se denuncian situaciones que } \\
\text { aquejan a la comunidad, tales como el cobro } \\
\text { exagerado de los arriendos o el vertedero de } \\
\text { aguas negras en las calles de la comunidad. }\end{array}$ \\
\hline & & & $\begin{array}{l}\text { Complicación o punto de quiebre: Don Afranio } \\
\text { presenta supuestos quebrantos de salud, lo cual } \\
\text { Ileva a Albeiro de tomar la decisión de involucrar } \\
\text { a Marisela en lo que está ocurriendo y esta } \\
\text { confronta a su padre frente a las quejas y }\end{array}$ \\
\hline
\end{tabular}




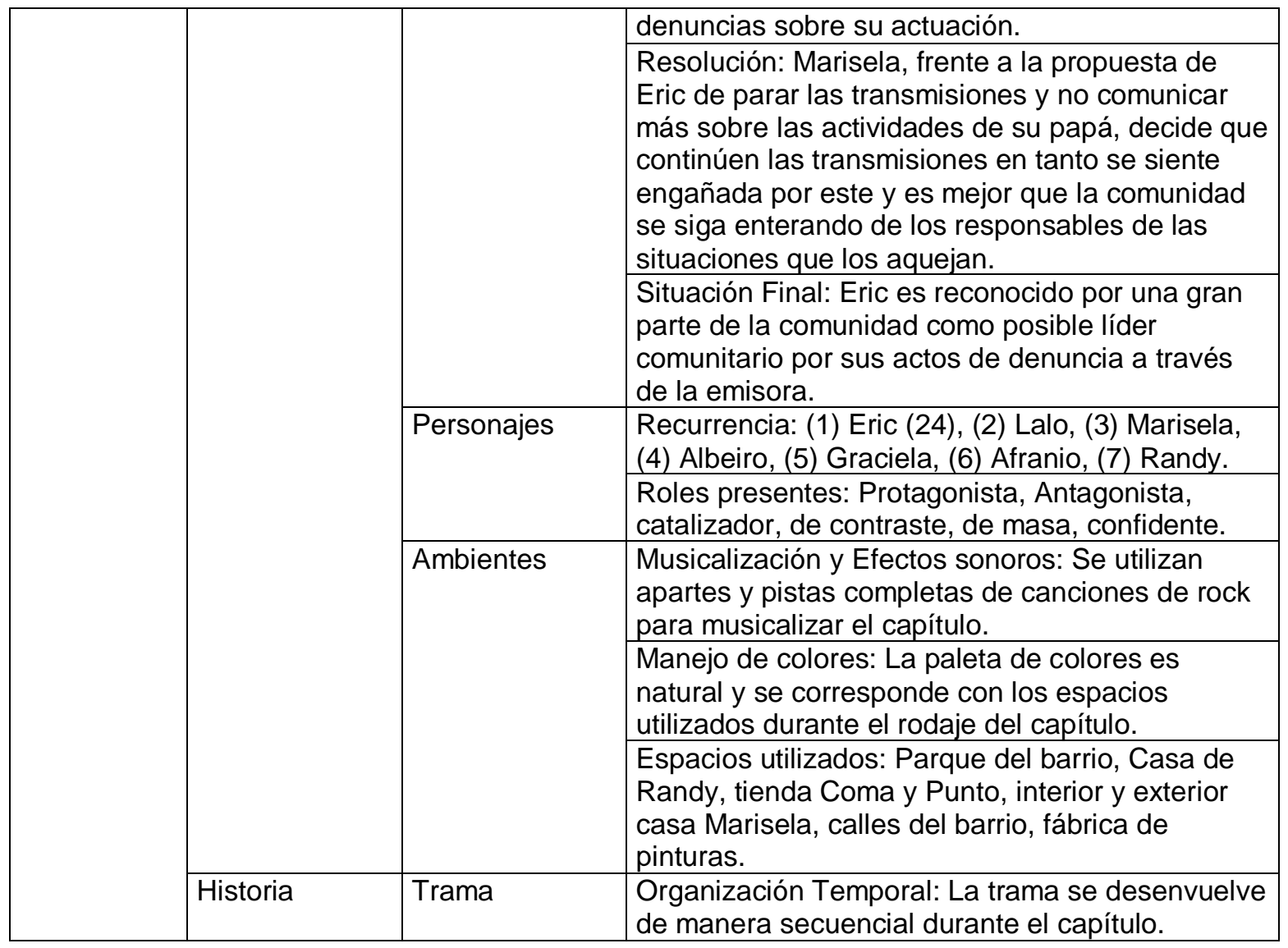

"Radio Lora", se plantea como continuación de lo planteado en el primer capítulo en tanto se mantiene la expectativa y la búsqueda de estrategias que le permitan a Eric ganarse un espacio de reconocimiento en la comunidad y acercarse a Marisela. Este episodio representa la relación que establece el joven con un medio de comunicación que, aun cuando no es contemporáneo con él, logra entender la funcionalidad de este para modificar las realidades que existen en el entorno. Se presentan varios elementos de atención durante este episodio: la emisora es creada por Randy, más como un experimento que por tener una real función para este medio de transmisión, de igual manera, se utiliza la banda corta o SW para generar las transmisiones, toda vez que esta banda no se encontraba regulada por ninguna entidad estatal importante y permitía obtener un alcance mayor al inicialmente previsto, lo cual les garantizó a los muchachos poder hacer llegar su voz a todos los rincones del barrio y generar un mayor impacto entre la población que podía acceder a ellos. Esto genera aún más diferencias y roces con Afranio, quien se ve involucrado en todas las denuncias que adelanta Eric a través 
de su programa en la emisora. En este capítulo, además, aparecen dos nuevos personajes mayores que brindan sustento temático a la historia y que amplifican el objetivo buscado por los muchachos a través de las denuncias. En otras palabras, se representa un nuevo tipo de relación entre los jóvenes y los adultos, principalmente, cuando está de por medio la estabilidad de la comunidad, y la manera de relacionarse con Afranio, quien hasta el momento ha fungido como una especie de "dueño del barrio" sin encontrar una clara oposición por parte de los vecinos. Los jóvenes y "Radio Lora" vienen a introducir una nueva variable en esta relación amplificando el conflicto, pero a su vez, dando nuevas herramientas de transformación de la cotidianidad del barrio. El conflicto en apariencia repercute en la salud de Afranio y esto, a su vez, en la relación de Marisela, tanto con Afranio, como con Eric y por extensión con los muchachos del grupo, toda vez que estos ocultan a Marisela en principio la emisora, en tanto es sabido que las denuncias iban a ir directamente en contra de Afranio y eso podría generar una disyuntiva para Marisela, en donde esta tendría que elegir entre ponerse del lado de sus amigos o del lado de su padre. Incluso, la otra temática (la relación que se establece entre Lalo y Graciela) parte de la necesidad de mantener alejado el núcleo de Marisela y Afranio de la existencia y el funcionamiento de la emisora. De igual manera, Albeiro intenta mostrarse como el contrapeso del liderazgo que ejerce Eric sobre los demás jóvenes, buscando centrar la discusión en otros temas e incluso, informándole a Marisela lo que estaba pasando con la emisora cuando ve que la salud de Afranio se encuentra comprometida.

A pesar de tener un carácter aficionado y no recibir algún tipo de dividendos económicos por ello, los jóvenes llevan a cabo algunos ejercicios de "investigación" periodística que les permite ampliar el alcance de las denuncias realizadas a través de la emisora, incluso, asumiendo otra identidad para ello.

Tabla 16. Matriz Temas / Tipo de Conflicto en el segundo capitulo

\begin{tabular}{|l|l|l|l|l|}
\hline \multirow{2}{*}{} & \multicolumn{1}{|c|}{ Tema de la trama } & \multicolumn{3}{c|}{ Tipo de conflicto } \\
\cline { 3 - 5 } $\mathrm{N}^{\circ}$ & & Personal & Social & Contextual \\
\hline 1 & Creación de la emisora & & & $\mathrm{X}$ \\
\hline 2 & Apertura del programa radial de Eric & & & $\mathrm{X}$ \\
\hline 3 & Relación Lalo - Graciela & $\mathrm{X}$ & & $\mathrm{X}$ \\
\hline 4 & Inicio de Transmisión - Denuncia sobre el alza de los & & $\mathrm{X}$ & $\mathrm{X}$ \\
\hline
\end{tabular}




\begin{tabular}{|l|l|l|l|l|}
\hline & arriendos & & & \\
\hline 5 & Denuncia de Aguas Negras & & $\mathrm{x}$ & $\mathrm{X}$ \\
\hline 6 & Conflicto Afranio - Jóvenes -Vecinos & & $\mathrm{x}$ & $\mathrm{x}$ \\
\hline
\end{tabular}

En la matriz anterior, se recogen las principales temáticas y las áreas en las que se concentran los conflictos reseñados en el capítulo. Por una parte, se evidencia que todo lo que involucra las denuncias por parte de los jóvenes y el conflicto subsecuente que se genera entre Afranio, los jóvenes y los vecinos del barrio acaparan la mayor cantidad de tiempo en pantalla con lo que se demuestra el impacto que tiene la puesta en práctica de la emisora sobre la dinámica que se venía llevando del barrio y que se ponen en tensión con el manejo que Afranio daba de las situaciones de conflicto en la comunidad. En este punto, es importante señalar que los vecinos del barrio, generalmente representados en las figuras de Don Francisco y Doña Tulia, sirven para brindar contexto al descontento que los vecinos del barrio han sentido con la situación en la cual Afranio muestra ascendencia sobre ellos y sobre las decisiones que se toman en el barrio. Escuchar la radio y el programa de denuncias de manera masiva y conjunta en la tienda "coma y punto" (tienda propiedad de Eric, Albeiro y la mama de estos), se incorpora a la dinámica del barrio y es allí, donde los vecinos deciden tomar acciones y medidas en contra de las posiciones de poder de Afranio sobre el barrio. Finalmente, esta posibilidad es la que, temporalmente, visibiliza a Eric y lo encumbra como una alternativa de líder en el barrio. Los conflictos, por tanto, pueden ser clasificados principalmente en dos ejes: Sociales y Contextuales, a excepción de la subtrama entre Lalo y Graciela, en tanto esta, aunque consecuencia de una trama mayor, involucra cambios en la relación entre Lalo y Graciela a nivel personal.

Tabla 17. Matriz Personajes / Conflictos / Valores en el segundo capítulo.

\begin{tabular}{|l|l|l|l|l|l|}
\hline Personaje & $\begin{array}{l}\text { Importancia } \\
\text { del personaje } \\
\text { (Protagónico/ } \\
\text { Antagónico/S } \\
\text { ecundario) }\end{array}$ & $\begin{array}{l}\text { Conflicto } \\
\text { (s) en el } \\
\text { que } \\
\text { participa } \\
\text { en el } \\
\text { capitulo }\end{array}$ & $\begin{array}{l}\text { Tipo de } \\
\text { Conflicto } \\
\text { (Personal/Social/ } \\
\text { Contextual) }\end{array}$ & $\begin{array}{l}\text { Actitud } \\
\text { frente al } \\
\text { conflicto }\end{array}$ & $\begin{array}{l}\text { Valores } \\
\text { asociados a } \\
\text { la actitud del } \\
\text { personaje }\end{array}$ \\
\hline Eric & Protagónico & $2,4,5,6$ & S, C & $\begin{array}{l}\text { (2) Proactiva, } \\
\text { (4) Proactiva, } \\
\text { (5) Proactiva, } \\
\text { (6) Apoyo }\end{array}$ & $\begin{array}{l}\text { Poder, Logro, } \\
\text { Estimulación, } \\
\text { autodirección }\end{array}$ \\
\hline Lalo & Protagónico & $2,3,5,6$ & P, S, C & (2) Apoyo, (3) & Universalismo, \\
\hline
\end{tabular}




\begin{tabular}{|c|c|c|c|c|c|}
\hline & & & & $\begin{array}{l}\text { Desidia, (5) } \\
\text { Apoyo, (6) } \\
\text { Proactiva }\end{array}$ & Autodirección \\
\hline Marisela & Protagónico & $4,5,6$ & S, C & $\begin{array}{l}\text { (4) Apoyo, (5) } \\
\text { Desconcierto, } \\
\text { (6) Rabia, } \\
\text { Desconcierto }\end{array}$ & $\begin{array}{l}\text { Benevolencia, } \\
\text { Conformidad }\end{array}$ \\
\hline Albeiro & Protagónico & $1,2,6$ & S, C & $\begin{array}{l}\text { (1) Proactivo, } \\
\text { (2) Apoyo, (6) } \\
\text { Entusiasta }\end{array}$ & $\begin{array}{l}\text { Estimulación, } \\
\text { Universalismo, } \\
\text { Benevolencia }\end{array}$ \\
\hline Graciela & Secundario & 3 & $\mathrm{P}$ & (3) Apoyo & Tradición \\
\hline Afranio & Antagónico & $4,5,6$ & S, C & $\begin{array}{l}\text { (4) Rabia, (5) } \\
\text { Rabia, } \\
\text { Desconcierto, } \\
\text { (6) Proactivo }\end{array}$ & $\begin{array}{l}\text { Poder, } \\
\text { Hedonismo, } \\
\text { Tradición }\end{array}$ \\
\hline Randy & Secundario & 1 & C & (1) Apoyo & Estimulación \\
\hline
\end{tabular}

\section{CAPITULO 3. RADIO LORA PARTE 2}

Tabla 18. Caracterización del tercer capítulo.

\begin{tabular}{|l|l|}
\hline Titulo & Radio Lora Parte 2 \\
\hline $\mathbf{N}^{\circ}$ de personajes & 16 \\
\hline $\begin{array}{l}\mathbf{N}^{\circ} \text { de apariciones } \\
\text { (por personaje- \# } \\
\text { escenas) }\end{array}$ & $\begin{array}{l}\text { (En orden de aparición) Marisela (6), Albeiro (13), Mireya (17), Randy } \\
(16), \text { Lalo (17), Eric (18), Nacho (4), Nancy (5), Afranio (9), Doña Tulia } \\
\text { (9), Don Francisco (7), policías (2), vendedor de pinturas (2), } \\
\text { vendedora de arepas (2), Don Lucio (2), vecinos (9), } \\
\text { carretilleros (2) }\end{array}$ \\
\hline Tema & $\begin{array}{l}\text { Se sigue ampliando el tema de la emisora que establecen los } \\
\text { muchachos y se exploran los conflictos que del uso que de esta dan, y } \\
\text { que se comienzan a generar con los vecinos del barrio y entre ellos } \\
\text { mismos. }\end{array}$ \\
\hline Director & \begin{tabular}{l} 
Harold Trompetero \\
\hline Tiempo
\end{tabular} \\
\hline Sinopsis & $\begin{array}{l}\text { Tras el éxito inicial de la emisora, los jóvenes deciden aumentar los } \\
\text { alcances de la emisora, denunciando nuevos casos y ampliando la } \\
\text { programación con un programa sobre sexualidad y afectividad dirigido } \\
\text { por Mireya. }\end{array}$ \\
\hline
\end{tabular}

Tabla 19. Ficha de análisis del tercer capítulo.

\begin{tabular}{|l|l|}
\hline \multicolumn{2}{|l|}{ Ficha de análisis del Capitulo } \\
\hline $\begin{array}{l}\text { Tema: Se sigue ampliando el } \\
\text { tema de la emisora que } \\
\text { establecen los jóvenes y se } \\
\text { exploran los conflictos que } \\
\text { del uso que de esta dan, y }\end{array}$ & Dominio de validez: Local \\
\cline { 2 - 2 } & \\
\hline
\end{tabular}




\begin{tabular}{|c|c|c|c|}
\hline \multicolumn{2}{|c|}{$\begin{array}{l}\text { que se comienzan a generar } \\
\text { con los vecinos del barrio y } \\
\text { entre ellos mismos. }\end{array}$} & & \\
\hline \multicolumn{2}{|c|}{ Estructura } & \multirow[t]{2}{*}{ Externa } & Ubicación Horaria: Nocturna \\
\hline & & & $\begin{array}{l}\text { Modo de emisión: Frecuencia de emisión } \\
\text { semanal }\end{array}$ \\
\hline \multirow[t]{9}{*}{$\begin{array}{l}\text { Análisis } \\
\text { Textual }\end{array}$} & \multirow[t]{9}{*}{ Relato } & \multirow[t]{5}{*}{$\begin{array}{l}\text { Situaciones o } \\
\text { funciones } \\
\text { narrativas }\end{array}$} & $\begin{array}{l}\text { Situación inicial: Después del éxito que han } \\
\text { tenido las transmisiones iniciales de la emisora, } \\
\text { los muchachos deciden que es tiempo de ampliar } \\
\text { la oferta de la emisora. Mireya propone que se } \\
\text { cree el programa "consultorio seximental", } \\
\text { mientras que Eric continúa con su programa de } \\
\text { denuncias en la comunidad. }\end{array}$ \\
\hline & & & $\begin{array}{l}\text { Puesta en escena: Durante el transcurso de las } \\
\text { transmisiones, que son apoyadas por la } \\
\text { comunidad, Afranio intenta hacer que cierren la } \\
\text { emisora en tanto esta afecta sus intereses en el } \\
\text { barrio. }\end{array}$ \\
\hline & & & $\begin{array}{l}\text { Complicación o punto de quiebre: Durante las } \\
\text { emisiones del "consultorio seximental", Randy } \\
\text { decide participar bajo el seudónimo de "el } \\
\text { inconforme" y Mireya se obsesiona con él. Eric } \\
\text { denuncia un puesto de empanadas que se instaló } \\
\text { en el barrio y esto trae consigo que la gente deje } \\
\text { de apoyarlo en su espacio de denuncias. }\end{array}$ \\
\hline & & & $\begin{array}{l}\text { Resolución: Randy, al ver que se desvirtúo su } \\
\text { idea inicial de la emisora, decide destruir los } \\
\text { equipos de la misma y de esta manera acabar } \\
\text { con las transmisiones. }\end{array}$ \\
\hline & & & $\begin{array}{l}\text { Situación Final: Se reconoce que es más } \\
\text { importante el bienestar de las relaciones entre el } \\
\text { grupo de amigos, que la relación que se estaba } \\
\text { presentando desde la emisora. }\end{array}$ \\
\hline & & \multirow[t]{2}{*}{ Personajes } & $\begin{array}{l}\text { Recurrencia: 1. Eric (18) 2. Lalo (17) 3. Mireya } \\
\text { (17) 4. Randy (16) 5. Albeiro (13) 6. Afranio (9) } 7 . \\
\text { Don Francisco (9) 8. Doña Tulia (9) }\end{array}$ \\
\hline & & & $\begin{array}{l}\text { Roles presentes: Protagonista, Antagonista, } \\
\text { catalizador, de interés romántico, de contraste, de } \\
\text { masa, confidente, temático. }\end{array}$ \\
\hline & & \multirow[t]{2}{*}{ Ambientes } & $\begin{array}{l}\text { Musicalización y Efectos sonoros: Se utilizan } \\
\text { apartes y pistas completas de canciones de rock } \\
\text { para musicalizar el capítulo. }\end{array}$ \\
\hline & & & $\begin{array}{l}\text { Manejo de colores: La paleta de colores es } \\
\text { natural y se corresponde con los espacios } \\
\text { utilizados durante el rodaje del capítulo. En una }\end{array}$ \\
\hline
\end{tabular}




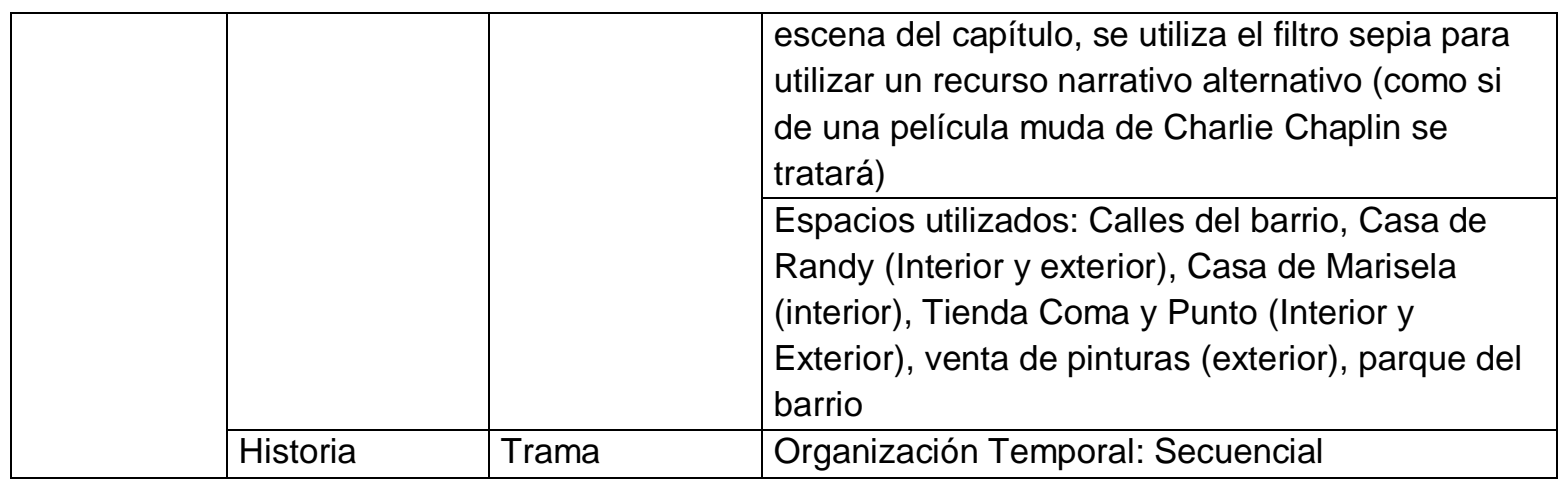

Este capítulo brinda un cierre a la trama iniciada en "Radio Lora", en tanto muestra los nuevos derroteros que se establecen en relación al uso de la emisora, ampliando su alcance e incluyendo la temática relativa a la vida sexual y emocional de los radioescuchas, parte importante en la vida de los jóvenes, esto introduce nuevas variables de conflicto y de interrelación entre ellos y una mayor receptividad y aceptación por parte de los adultos en el contexto. A pesar de tener el apoyo de la gran mayoría del barrio, las circunstancias empiezan a cambiar a favor de Afranio cuando deciden realizar una denuncia contra una abuela, vendedora ambulante, por lo cual esta pierde su puesto ambulante, situación que genera quejas e incomodidades por parte de los vecinos que antes apoyaban a los muchachos, lo que muestra que incluso para los jóvenes existen temas vedados y con los cuales no se deben meter: una señora de avanzada edad, de bajos recursos y de la cual dependen otras personas. Así, se muestra las limitaciones que se imponen a la juventud y que no todos los territorios les son permitidos transgredir. La comunidad ejerce igual un control social sobre aquello que le es y no es permitido al joven dentro de su contexto. Finalmente, la expresión de emociones a través del programa "consultorio seximental", abre otro tema importante y es la relación de los jóvenes con su sexualidad y su emocionalidad. Es interesante la escogencia de Mireya y Randy para ilustrar esta dualidad puesto que, tanto Mireya como Randy son personajes ubicados en polos opuestos frente a esta temática, mientras Mireya es una mujer con una mentalidad más liberal y que se fija en las fuertes emociones, Randy es más reservado y sensible, lo cual termina planteando una mirada alternativa en la relación que se establece entre ambos personajes. La conjunción de todas estas situaciones, desencadenan el fin de la emisora en manos de su propio creador, mostrando que la 
estabilidad del grupo y de la comunidad está por encima de los deseos personales de quienes hicieron uso del medio.

Tabla 20. Matriz Temas / Tipo de Conflicto del tercer capítulo.

\begin{tabular}{|l|l|l|l|l|}
\hline \multicolumn{1}{|c|}{ Tema de la trama } & \multicolumn{3}{c|}{ Tipo de conflicto } \\
\cline { 3 - 5 } & & Personal & Social & Contextual \\
\hline$N^{\circ}$ & & & $X$ & $X$ \\
\hline 1 & Denuncias a través de la emisora & $X$ & $X$ & $X$ \\
\hline 2 & Consultorio seximental & & & $\mathrm{X}$ \\
\hline 3 & Intento de cierre de la emisora & & $\mathrm{X}$ & \\
\hline 4 & Confrontación Vecinos-Don Afranio & & $\mathrm{X}$ \\
\hline 5 & Cierre de la emisora & & \multicolumn{3}{|c|}{} \\
\hline
\end{tabular}

En la matriz anterior, se recogen las principales temáticas y las áreas en las que se concentran los conflictos reseñados en el capítulo. Al ser una continuación de capitulo anterior, en donde se construye una dinámica de construcción de espacios de denuncia de situaciones que afectan la comunidad desde el medio de comunicación que llevan los jóvenes, es esta temática junto con la del consultorio seximental las que acaparan la mayoría del metraje del capítulo analizado. Las otras dos temáticas que se reparten el resto del metraje, pueden ser entendidas como consecuencias de lo que se plantean en las temáticas 1 y 2, por lo que aquí se centra el recorrido en las dos primeras temáticas abordadas en el capítulo. Las denuncias continúan en la línea de lo que se planteó durante la primera parte de dos con la misma historia alrededor del medio de comunicación creado por los jóvenes, y con la segunda temática (el consultorio seximental) se brinda la oportunidad de profundizar en los pensamientos y creencias de dos personajes, hasta el momento secundarios, como Mireya y Randy, y derivan en el conflicto final de Randy sobre el objetivo y finalidad del medio que fue construido inicialmente por él, y que en el camino se desvirtuó de su planteamiento inicial. En definitiva, las dos más grandes temáticas que se abordan en este capítulo, encierran dos conflictos de tipo Social y Contextual. El accionar de los jóvenes, a través de la emisora, repercute en las acciones que se toman desde la comunidad, para resolver los conflictos que se generan en la dinámica que viene liderando quien se conforma como antagonista, no solo de los jóvenes sino además de las posibilidades de la comunidad para salir adelante y en las relaciones entre los miembros de los distintos grupos generacionales. 
Tabla 21. Matriz Personajes / Conflictos / Valores.

\begin{tabular}{|c|c|c|c|c|c|}
\hline Personaje & $\begin{array}{l}\text { Importancia } \\
\text { del } \\
\text { personaje } \\
\text { (/Protagónic } \\
\text { o/Antagonist } \\
\text { a/Secundario } \\
\text { ) }\end{array}$ & $\begin{array}{l}\text { Conflict } \\
\text { o(s) en } \\
\text { el que } \\
\text { participa } \\
\text { en el } \\
\text { capitulo }\end{array}$ & $\begin{array}{l}\text { Tipo de } \\
\text { Conflicto } \\
\text { (Personal/S } \\
\text { ocial/Contex } \\
\text { tual) }\end{array}$ & $\begin{array}{l}\text { Actitud frente } \\
\text { al conflicto }\end{array}$ & $\begin{array}{l}\text { Valores } \\
\text { asociados a la } \\
\text { actitud del } \\
\text { personaje }\end{array}$ \\
\hline Eric & Protagónico & $1,3,4$ & S, C & $\begin{array}{l}\text { (1) Proactivo, } \\
\text { (3) Proactiva- } \\
\text { entusiasta, (4) } \\
\text { Proactiva- } \\
\text { Apoyo }\end{array}$ & $\begin{array}{l}\text { Estimulación, } \\
\text { Universalismo, } \\
\text { Logro, Poder }\end{array}$ \\
\hline Lalo & Protagónico & $2,3,5$ & $\mathrm{P}, \mathrm{S}, \mathrm{C}$ & $\begin{array}{l}\text { (2) Apoyo, (3) } \\
\text { Proactividad- } \\
\text { Apoyo, (5) } \\
\text { Apoyo }\end{array}$ & $\begin{array}{l}\text { Conformidad, } \\
\text { Universalismo, } \\
\text { Benevolencia }\end{array}$ \\
\hline Mireya & Protagónico & $2,3,5$ & $\mathrm{P}, \mathrm{S}, \mathrm{C}$ & $\begin{array}{l}\text { (2) Proactiva- } \\
\text { Entusiasta, (3) } \\
\text { Proactiva- } \\
\text { Apoyo, (5) } \\
\text { Desconcierto }\end{array}$ & $\begin{array}{l}\text { Hedonismo, } \\
\text { Estimulación, } \\
\text { Seguridad, } \\
\text { Universalismo }\end{array}$ \\
\hline Randy & Protagónico & $2,3,5$ & $\mathrm{P}, \mathrm{S}, \mathrm{C}$ & $\begin{array}{l}\text { (2) Apoyo- } \\
\text { entusiasta, (3) } \\
\text { Proactivo- } \\
\text { Entusiasta, (5) } \\
\text { Rabia- } \\
\text { Proactivo }\end{array}$ & $\begin{array}{l}\text { Autodirección, } \\
\text { Tradición, } \\
\text { Benevolencia }\end{array}$ \\
\hline Albeiro & Secundario & $1,3,4,5$ & $\mathrm{P}, \mathrm{S}, \mathrm{C}$ & $\begin{array}{l}\text { (1) Apoyo, } \\
\text { (3)Proactivo- } \\
\text { apoyo, } \\
\text { (4)Proactivo- } \\
\text { entusiasta, } \\
\text { (5)Apoyo }\end{array}$ & $\begin{array}{l}\text { Universalismo, } \\
\text { Benevolencia, } \\
\text { Conformidad }\end{array}$ \\
\hline Afranio & Antagonista & $1,3,4$ & S, C & $\begin{array}{l}\text { (1) Rabia, (3) } \\
\text { Proactividad, } \\
\text { (4) Rabia- } \\
\text { Desidia }\end{array}$ & Poder, Tradición. \\
\hline Doña Tulia & Secundario & 1,4 & S, C & $\begin{array}{l}\text { (1) Apoyo- } \\
\text { Rabia, (4) } \\
\text { Rabia- } \\
\text { Proactividad }\end{array}$ & $\begin{array}{l}\text { Universalismo, } \\
\text { Benevolencia. }\end{array}$ \\
\hline $\begin{array}{l}\text { Don } \\
\text { Francisco }\end{array}$ & Secundario & 1,4 & S, C & $\begin{array}{l}\text { (1) Apoyo- } \\
\text { Rabia, (4) } \\
\text { Rabia- } \\
\text { Proactividad }\end{array}$ & $\begin{array}{l}\text { Universalismo, } \\
\text { Benevolencia. }\end{array}$ \\
\hline
\end{tabular}




\section{CAPITULO 4. MAHATMA RANDHI}

Tabla 22. Caracterización del cuarto capítulo.

\begin{tabular}{|l|l|}
\hline Titulo & Mahatma Randhi \\
\hline $\mathbf{N}^{\circ}$ de personajes & 16 \\
\hline $\begin{array}{l}\mathbf{N}^{\circ} \text { de apariciones } \\
\text { (por personaje- \# } \\
\text { escenas) }\end{array}$ & $\begin{array}{l}\text { (En orden de aparición) Marisela (4), Albeiro (14), Randy (20), Lalo (2), } \\
\text { Eric (12), Nacho (11), Nancy (12), Julio (14), Andy (14), Afranio (9), } \\
\text { Vecinos (16), Doña Tulia (8), Doña Emilia (21), Señor Isaza (19), } \\
\text { Guardas (7), Policías (1) }\end{array}$ \\
\hline Tema & $\begin{array}{l}\text { Don Afranio quiere utilizar un predio que se encuentra desocupado en } \\
\text { el barrio para construir un supermercado en él, sin embargo, pone en } \\
\text { riesgo no solo el espacio de juego de los niños del barrio, sino la } \\
\text { tranquilidad de la comunidad. Frente a esto, Randy decide utilizar la } \\
\text { toma pacifica, propuesta por Gandhi, para enfrentarse a las intenciones } \\
\text { de Don Afranio. }\end{array}$ \\
\hline Director & $\begin{array}{l}\text { Harold Trompetero } \\
\text { Tiempo }\end{array}$ \\
\hline Sinopsinutos \\
\hline $\begin{array}{l}\text { Después de encontrar un posible nuevo negocio, Don Afranio tendrá } \\
\text { imponiendo su voluntad sobre las necesidades de la comunidad. }\end{array}$ \\
\hline
\end{tabular}

Tabla 23. Ficha de análisis del cuarto capítulo.

\begin{tabular}{|c|c|c|c|}
\hline \multicolumn{4}{|c|}{ Ficha de análisis del Capitulo } \\
\hline \multirow{2}{*}{\multicolumn{2}{|c|}{ Tema: }} & \multicolumn{2}{|c|}{ Dominio de validez: Local } \\
\hline & & \multicolumn{2}{|c|}{ Carácter: Publico } \\
\hline \multirow{2}{*}{\multicolumn{2}{|c|}{ Estructura }} & \multirow[t]{2}{*}{ Externa } & Ubicación Horaria: Nocturna \\
\hline & & & $\begin{array}{l}\text { Modo de emisión: Frecuencia de emisión } \\
\text { semanal }\end{array}$ \\
\hline \multirow[t]{2}{*}{$\begin{array}{l}\text { Análisis } \\
\text { Textual }\end{array}$} & \multirow[t]{2}{*}{ Relato } & \multirow[t]{2}{*}{$\begin{array}{l}\text { Situaciones o } \\
\text { funciones } \\
\text { narrativas }\end{array}$} & $\begin{array}{l}\text { Situación inicial: Niños del barrio, incluyendo a } \\
\text { Andy (hermano de Randy), se encuentran } \\
\text { jugando en una propiedad abandonada del barrio, } \\
\text { que es de interés de Afranio para apoderarse de } \\
\text { ella, en medio de la persecución de Andy, Afranio } \\
\text { se confronta con Randy y los vecinos del barrio, } \\
\text { incluyendo a los muchachos del grupo. }\end{array}$ \\
\hline & & & $\begin{array}{l}\text { Puesta en escena: Siguiendo las indicaciones de } \\
\text { Randy, los vecinos tratan de confrontar a Afranio } \\
\text { en la búsqueda de soluciones por la vía pacífica, } \\
\text { sin embargo, Afranio decide ponerle seguridad }\end{array}$ \\
\hline
\end{tabular}




\begin{tabular}{|c|c|c|}
\hline & & $\begin{array}{l}\text { privada al predio abandonado, ante lo cual Randy } \\
\text { decide hacer una toma pacifica del mismo, } \\
\text { siguiendo la filosofía de Mahatma Gandhi. } \\
\text { Complicación o punto de quiebre: Al ver la actitud } \\
\text { de Randy frente a la situación, los vecinos del } \\
\text { barrio "sacralizan" a Randy, convirtiéndolo en } \\
\text { prácticamente un líder con características } \\
\text { religiosas, señalándole "milagros" y realizando } \\
\text { romerías para ir a tomar consejo. }\end{array}$ \\
\hline & & $\begin{array}{l}\text { Resolución: Afranio decide utilizar también una } \\
\text { "retoma" pacifica del predio, ante lo cual los } \\
\text { muchachos y la gente le reclaman a Randy más } \\
\text { acciones, situación frente a la cual Randy no está } \\
\text { preparado y la gente, cansada por la situación, } \\
\text { decide confrontarse con los guardas y Afranio. } \\
\text { En medio de esto, Andy es agredido por un perro } \\
\text { de los guardas y los muchachos intervienen para } \\
\text { ayudar al niño. }\end{array}$ \\
\hline & & $\begin{array}{l}\text { Situación Final: Randy decide levantar la toma } \\
\text { pacifica e irse a su casa, ante lo cual los vecinos, } \\
\text { preocupados se preguntan qué hacer y Eric les } \\
\text { recrimina esta actitud. }\end{array}$ \\
\hline & Personajes & $\begin{array}{l}\text { Recurrencia: Doña Emilia (21), Randy (20), Señor } \\
\text { Isaza (19), Julio (14), Andy (14), Albeiro (14), } \\
\text { Vecinos (16), Eric (12), Nancy (12), Afranio (9) }\end{array}$ \\
\hline & & $\begin{array}{l}\text { Roles presentes: Protagonista, Antagonista, } \\
\text { catalizador, de contraste, de masa, confidente, } \\
\text { temático. }\end{array}$ \\
\hline & Ambientes & $\begin{array}{l}\text { Musicalización y Efectos sonoros: Se utilizan } \\
\text { apartes y pistas completas de canciones de rock } \\
\text { para musicalizar el capítulo. }\end{array}$ \\
\hline & & $\begin{array}{l}\text { Manejo de colores: Se utiliza la luz y los colores } \\
\text { naturales de cada uno de los espacios utilizados } \\
\text { para la grabación del capítulo. }\end{array}$ \\
\hline & & $\begin{array}{l}\text { Espacios utilizados: predio abandonado (interior y } \\
\text { exterior), calles del barrio, tienda "coma y punto" } \\
\text { (interior), casa de Marisela (exterior). }\end{array}$ \\
\hline Historia & Trama & Organización Temporal: Secuencial \\
\hline
\end{tabular}

Este capítulo puede ser entendido como un episodio de transición en el manejo narrativo de las historias y las temáticas en la serie. "Mahatma Randhi", es un episodio en donde se visualiza la influencia que pueden llegar a tener los jóvenes sobre la comunidad y la manera en que las creencias sociales y culturales terminan modificando el accionar de la 
misma frente a las propuestas de acción y transformación social que proponen los jóvenes para confrontar las situaciones que perjudican los intereses de todo el barrio.

Es particular señalar que, en este episodio, un personaje generalmente secundario como Randy toma la batuta del grupo de jóvenes y es quien plantea las acciones a seguir para confrontar al siempre dominante Sr. Afranio y sus intencionalidades de ocupar un espacio que podría ser utilizado de otra manera por parte de la comunidad. En este proceso de confrontación, utilizando las estrategias de afrontamiento propuestas por Mahatma Gandhi (de donde se obtiene el nombre del capítulo), se termina confundiendo la motivación de Randy con el deseo de la comunidad por tener una imagen cuasi religiosa a la cual acudir para intentar solucionar problemáticas personales y particulares que no corresponden con la necesidad original que trata de resolver Randy con su actitud.

Se explora así, los mecanismos que utilizan los jóvenes para acometer acciones de cambio y transformación social en la comunidad y como la misma comunidad absorbe estas acciones desde sus creencias sociales y culturales, primando las necesidades particulares sobre las necesidades públicas de estos mismos.

Tabla 24. Matriz Temas / Tipo de Conflicto del cuarto capítulo.

\begin{tabular}{|l|l|l|l|l|}
\hline \multirow{2}{*}{} & \multicolumn{1}{|c|}{ Tema de la trama } & \multicolumn{3}{|c|}{ Tipo de conflicto } \\
\cline { 3 - 5 } & & $\begin{array}{l}\text { Perso } \\
\text { nal }\end{array}$ & Social & Contextual \\
\hline 1 & Uso de predio abandonado que pretende tomar Don Afranio & & $\mathrm{X}$ & $\mathrm{X}$ \\
\hline 2 & Confrontación comunidad - Don Afranio & & $\mathrm{X}$ & $\mathrm{X}$ \\
\hline 3 & Toma pacifica del predio & & $\mathrm{X}$ & $\mathrm{X}$ \\
\hline 4 & Correría con tintes religiosos alrededor de la figura de Randy & & $\mathrm{X}$ & $\mathrm{X}$ \\
\hline 5 & Enfermedad Andy/Randy & $\mathrm{X}$ & & \\
\hline
\end{tabular}

En la matriz anterior, se recogen las principales temáticas y las áreas en las que se concentran los conflictos reseñados en el capítulo. Los conflictos se concentran, principalmente, en tres grandes temáticas: La confrontación comunidad - Don Afranio, toma pacifica del predio y la correría con tintes religiosos alrededor de la figura de Randy, convirtiendo este, en un capítulo con un alto contenido de conflictos sociales y contextuales mostrando además la movilización social y las acciones que se asumen desde la juventud para buscar la transformación y el cambio social de las situaciones adversas a las que se ve sometida la comunidad, incluso si esta proviene de otro de los miembros reconocidos por la comunidad. De igual forma, una temática como la correría con tintes religiosos, es un retrato de lo que muchas comunidades colombianas realizan 
al buscar un modelo a seguir: lo idealizan, le brindan características supernaturales, y consideran que tienen que, de alguna forma, hacerlo sentir bien para conseguir beneficios del supuesto elemento que les brindará una seguridad y un bienestar inesperado.

Tabla 25. Matriz Personajes / Conflictos / Valores del cuarto capítulo.

\begin{tabular}{|c|c|c|c|c|c|}
\hline Personaje & $\begin{array}{l}\text { Importancia del } \\
\text { personaje } \\
\text { (Protagónico/S } \\
\text { ecundario) }\end{array}$ & $\begin{array}{l}\text { Conflicto(s) } \\
\text { en el que } \\
\text { participa en } \\
\text { el capitulo }\end{array}$ & $\begin{array}{l}\text { Tipo de } \\
\text { Conflicto } \\
\text { (Personal/Soc } \\
\text { ial/Contextual } \\
\text { ) }\end{array}$ & $\begin{array}{l}\text { Actitud frente } \\
\text { al conflicto }\end{array}$ & $\begin{array}{l}\text { Valores } \\
\text { asociados a la } \\
\text { actitud del } \\
\text { personaje }\end{array}$ \\
\hline Doña Emilia & Secundario & $2,3,4$ & S, C & $\begin{array}{l}\text { (2) Apoyo, (3) } \\
\text { Apoyo, (4) } \\
\text { Entusiasta }\end{array}$ & $\begin{array}{l}\text { Universalismo, } \\
\text { Benevolencia }\end{array}$ \\
\hline Randy & Protagónico & $1,2,3,4,5$ & $\mathrm{P}, \mathrm{S}, \mathrm{C}$ & $\begin{array}{l}\text { (1) Rabia, (2) } \\
\text { Proactivo, (3) } \\
\text { Proactivo- } \\
\text { Entusiasta, (4) } \\
\text { Desconcierto- } \\
\text { Desidia, (5) } \\
\text { Desconcierto }\end{array}$ & $\begin{array}{l}\text { Estimulación, } \\
\text { Autodirección, } \\
\text { Universalismo, } \\
\text { Benevolencia, } \\
\text { Seguridad. }\end{array}$ \\
\hline Señor Isaza & Secundario & $2,3,4$ & S, C & $\begin{array}{l}\text { (2) Apoyo, (3) } \\
\text { Apoyo, (4) } \\
\text { Entusiasta }\end{array}$ & $\begin{array}{l}\text { Universalismo, } \\
\text { Benevolencia }\end{array}$ \\
\hline Albeiro & Secundario & $2,3,4$ & S, C & $\begin{array}{l}\text { (2) Apoyo, (3) } \\
\text { Apoyo, (4) } \\
\text { Desconcierto }\end{array}$ & $\begin{array}{l}\text { Universalismo, } \\
\text { Benevolencia }\end{array}$ \\
\hline Julio & Secundario & $2,3,4$ & S, C & $\begin{array}{l}\text { (2) Apoyo, (3) } \\
\text { Apoyo, (4) } \\
\text { Entusiasta }\end{array}$ & $\begin{array}{l}\text { Universalismo, } \\
\text { Benevolencia }\end{array}$ \\
\hline Andy & Secundario & $1,4,5$ & $\mathrm{P}, \mathrm{S}, \mathrm{C}$ & $\begin{array}{l}\text { (1) Entusiasta, } \\
\text { (4) proactivo, (5) } \\
\text { Apoyo }\end{array}$ & $\begin{array}{l}\text { Hedonismo, } \\
\text { Estimulación, } \\
\text { Autodirección }\end{array}$ \\
\hline
\end{tabular}




\section{CAPITULO 5. EL TV CABLE}

Tabla 26. Caracterización del quinto capítulo.

\begin{tabular}{|l|l|}
\hline Titulo & El TV Cable \\
\hline $\mathbf{N}^{\circ}$ de personajes & 12 \\
\hline $\begin{array}{l}\mathbf{N}^{\circ} \text { de apariciones } \\
\text { (por personaje- \# } \\
\text { escenas) }\end{array}$ & $\begin{array}{l}\text { (En orden de aparición) Marisela (15), Albeiro (9), Mireya (10), Randy } \\
\text { (15), Lalo (15), Eric (18), Nacho (9), Nancy, (11), Andy (4), dueño del } \\
\text { bar (3), Afranio (5), Vecinos (5) }\end{array}$ \\
\hline Tema & $\begin{array}{l}\text { Los conflictos que se generan entre los muchachos alrededor de un } \\
\text { sistema de TV por Cable al cual logran acceder de manera fraudulenta. }\end{array}$ \\
\hline Director & Harold Trompetero \\
\hline Tiempo & $\begin{array}{l}\text { 43 minutos 41 segundos } \\
\text { Sinopsis }\end{array}$ \\
$\begin{array}{l}\text { Dondy descubre una forma de tomar la señal de TV Cable que ofrece } \\
\text { ofrecer este servicio puede tener para generar ingresos, pero esto le } \\
\text { trae nuevos conflictos. }\end{array}$ \\
\hline
\end{tabular}

Tabla 27. Ficha de análisis del quinto capítulo.

\begin{tabular}{|c|c|c|c|}
\hline \multicolumn{4}{|c|}{ Ficha de análisis del Capitulo } \\
\hline \multirow{2}{*}{\multicolumn{2}{|c|}{ Tema: }} & \multicolumn{2}{|c|}{ Dominio de validez: Local } \\
\hline & & \multicolumn{2}{|c|}{ Carácter: Publico } \\
\hline \multirow{2}{*}{\multicolumn{2}{|c|}{ Estructura }} & \multirow[t]{2}{*}{ Externa } & Ubicación Horaria: Nocturna \\
\hline & & & $\begin{array}{l}\text { Modo de emisión: Frecuencia de emisión } \\
\text { semanal }\end{array}$ \\
\hline $\begin{array}{l}\text { Análisis } \\
\text { Textual }\end{array}$ & Relato & $\begin{array}{l}\text { Situaciones o } \\
\text { funciones } \\
\text { narrativas }\end{array}$ & $\begin{array}{l}\text { Situación inicial: En casa de Nancy, Randy } \\
\text { encuentra la manera de hacer un cableado } \\
\text { fraudulento tomando la señal del TV Cable que } \\
\text { ofrece Afranio al Barrio, y asegura que el conoce } \\
\text { decodificadores con más canales y que no es tan } \\
\text { caro. Los muchachos se reúnen durante todo el } \\
\text { día en casa de Nancy para ver la televisión. } \\
\text { Puesta en escena: Eric decide convencer a } \\
\text { Randy que monten la señal con el decodificador } \\
\text { del que hablo, y este empieza a armar el sistema. } \\
\text { En casa de Nancy, Marisela empieza a sentirse } \\
\text { incomoda con las continuas visitas de los } \\
\text { muchachos. } \\
\text { Complicación o punto de quiebre: Randy se da } \\
\text { cuenta que Eric se está lucrando con el sistema } \\
\text { de cable en el que estuvo trabajando, sin recibir } \\
\text { lo justo en lo económico, mientras que Eric saca } \\
\text { dinero de la cuenta del bar donde trabaja sin }\end{array}$ \\
\hline
\end{tabular}




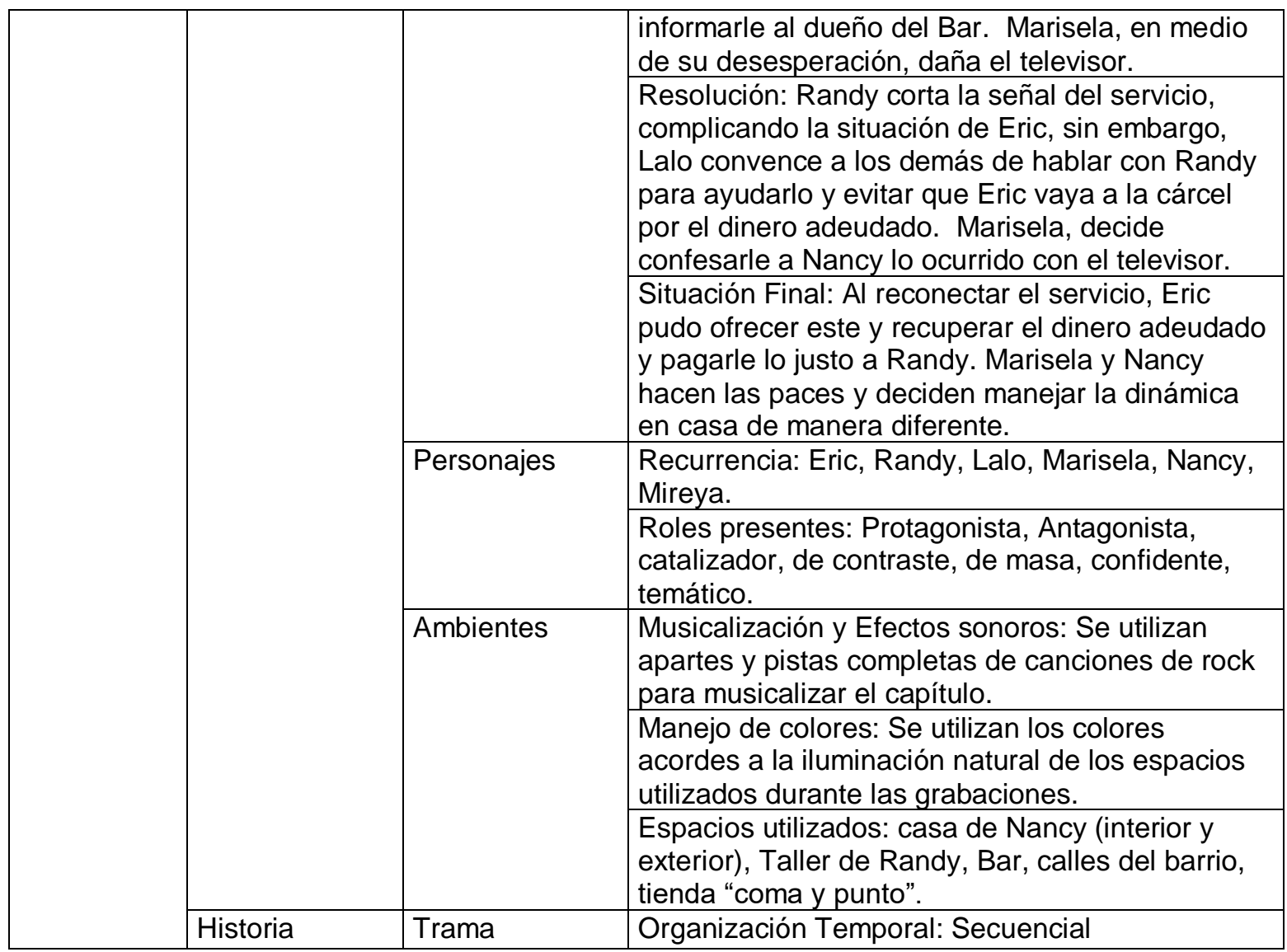

Como último capítulo de la muestra analizada, este tiene algunas particularidades que son importantes de reseñar. Por una parte, es de los capítulos más avanzados en el tiempo de la obra audiovisual, con lo cual ya denotaba un desgaste a nivel narrativo y las herramientas que se utilizaban para enriquecer la narrativa de las tramas, son utilizadas en una menor medida. Los conflictos que repercuten en la comunidad, aunque también se encuentran presentes durante el metraje, pierden su peso en la trama y pasan a ser secundarios, convirtiéndose los conflictos entre los jóvenes del grupo en elemento central de la trama que se aborda en el episodio.

Al centrarse en una situación de la cual Eric quiere sacar redito y beneficio particular, se generan una serie de conflictos y divisiones al interior del grupo, en donde hasta cuatro de los personajes se confrontan por querer beneficios para ellos mismos y no para el bienestar de ellos como grupo o de la comunidad circundante. Es así, como Eric y Randy se confrontan por lo que Randy considera un abuso por parte de Eric en el manejo 
que se da de algo que finalmente no tiene características legales ni tampoco pretendía generar un beneficio más allá del que se pudiera disponer. Por otra parte, Marisela y Nancy también entran en conflicto por la convivencia en la casa de Nancy, toda vez que ambas asumen posiciones distintas frente a la nueva tecnología de la que disponen.

Este episodio nos muestra la manera en que los jóvenes resuelven sus diferencias y problemas entre ellos, de manera positiva y, sobre todo, colocando por encima de los intereses personales y particulares los intereses y el bienestar de todo el grupo en general, esto particularmente evidente en el abordaje de parte de todos los jóvenes en la situación conflictiva entre Eric-Randy y la intervención de Lalo para que Marisela y Nancy acercarán sus posturas alrededor de las diferencias frente al manejo de los espacios comunes.

Tabla 28. Matriz Temas / Tipo de Conflicto del quinto capítulo.

\begin{tabular}{|l|l|l|l|l|}
\hline N & \multicolumn{1}{|c|}{ Tema de la trama } & \multicolumn{3}{c|}{ Tipo de conflicto } \\
\cline { 3 - 5 } & & Personal & Social & Contextual \\
\hline 1 & Conexión fraudulenta del tv cable al televisor de Nancy & & & $\mathrm{X}$ \\
\hline 2 & $\begin{array}{l}\text { Estructuración de empresa de tv cable no legal por } \\
\text { parte de Eric y Randy }\end{array}$ & & $\mathrm{X}$ & $\mathrm{X}$ \\
\hline 3 & Conflicto Marisela/Nancy & $\mathrm{X}$ & & $\mathrm{X}$ \\
\hline 4 & Conflicto Eric/Randy & $\mathrm{x}$ & & $\mathrm{X}$ \\
\hline
\end{tabular}

En la matriz anterior, se recogen las principales temáticas y las áreas en las que se concentran los conflictos reseñados en el capítulo. Es posible observar como las problemáticas que se suceden por la construcción de la infraestructura del TV cable entre los miembros del grupo de jóvenes ocupa la mayor parte de la trama y el metraje del episodio, mientras que la estructuración de la empresa no legal de TV cable comprende otra parte importante. Esto muestra que las problemáticas y conflictos que se suscitan dentro de este capítulo son más de carácter personal y Contextual y no se presenta mayor impacto en el entorno social en el cual se mueven los personajes, lo que muestra que en este capítulo la importancia del contexto social pierde su vigencia y la narrativa se torna más hacia las relaciones entre los personajes juveniles de la serie y como estos resuelven sus diferencias. 
Tabla 29. Matriz Personajes / Conflictos / Valores del quinto capítulo.

\begin{tabular}{|c|c|c|c|c|c|}
\hline Personaje & $\begin{array}{l}\text { Importancia del } \\
\text { personaje } \\
\text { (Protagónico/S } \\
\text { ecundario) }\end{array}$ & $\begin{array}{l}\text { Conflicto(s) } \\
\text { en el que } \\
\text { participa en } \\
\text { el capitulo }\end{array}$ & $\begin{array}{l}\text { Tipo de } \\
\text { Conflicto } \\
\text { (Personal/S } \\
\text { ocial/Contex } \\
\text { tual) }\end{array}$ & $\begin{array}{l}\text { Actitud } \\
\text { frente al } \\
\text { conflicto }\end{array}$ & $\begin{array}{l}\text { Valores } \\
\text { asociados a } \\
\text { la actitud del } \\
\text { personaje }\end{array}$ \\
\hline Eric & Protagónico & $1,2,4$ & $\mathrm{C}, \mathrm{S}, \mathrm{P}$ & $\begin{array}{l}(1) \\
\text { Entusiast } \\
\text { a-apoyo, } \\
(2) \\
\text { Proactivo- } \\
\text { Entusiast } \\
\text { a, (3) } \\
\text { Desidia }\end{array}$ & $\begin{array}{l}\text { Poder, Logro, } \\
\text { Hedonismo, } \\
\text { Autodirección }\end{array}$ \\
\hline Randy & Secundario & $1,2,4$ & $\mathrm{C}, \mathrm{S}, \mathrm{P}$ & $\begin{array}{l}(1) \\
\text { Proactivo, } \\
(2) \\
\text { Apoyo- } \\
\text { entusiasta } \\
\text { (4) Rabia- } \\
\text { Desconci } \\
\text { erto }\end{array}$ & $\begin{array}{l}\text { Estimulación, } \\
\text { Universalismo, } \\
\text { Benevolencia }\end{array}$ \\
\hline Lalo & Secundario & 1,4 & $\mathrm{C}, \mathrm{P}$ & $\begin{array}{l}\text { (1) Apoyo } \\
\text { Entusiast } \\
\text { a, (4) } \\
\text { Apoyo }\end{array}$ & $\begin{array}{l}\text { Conformidad, } \\
\text { Tradición }\end{array}$ \\
\hline Marisela & Protagónico & 1,3 & $\mathrm{C}, \mathrm{P}$ & $\begin{array}{l}\text { (1) Apoyo } \\
\text { Entusiast } \\
\text { a, (3) } \\
\text { Rabia- } \\
\text { Desconci } \\
\text { erto }\end{array}$ & $\begin{array}{l}\text { Conformidad, } \\
\text { Tradición }\end{array}$ \\
\hline Nancy & Secundario & 1,3 & $\mathrm{C}, \mathrm{P}$ & $\begin{array}{l}\text { (1) Apoyo } \\
\text { Entusiast } \\
\text { a, (3) } \\
\text { Rabia- } \\
\text { Desconci } \\
\text { erto }\end{array}$ & $\begin{array}{l}\text { Hedonismo, } \\
\text { Autodirección }\end{array}$ \\
\hline Mireya & Secundario & 1,4 & $\mathrm{C}, \mathrm{P}$ & $\begin{array}{l}\text { (1) Apoyo } \\
\text { Entusiast } \\
\text { a, (4) } \\
\text { Apoyo }\end{array}$ & $\begin{array}{l}\text { Universalismo, } \\
\text { Benevolencia, } \\
\text { Tradición }\end{array}$ \\
\hline
\end{tabular}

\subsection{Organización de datos relevantes}

Pasada la etapa de recolección de datos recabados de la visualización de los capítulos que componen la muestra, se procede a estructurarlos con miras a resolver los objetivos planteados al inicio de la investigación. En primera instancia, se estructurarán alrededor 
de las categorías planteadas, acorde a la construcción de las matrices para recolectar la información y posteriormente, a partir de las descripciones que acompañan las matrices de cada personaje en cada capítulo, se estructurará información adicional en categorías emergentes para su análisis.

Con el fin de optimizar este proceso, se procederá a tomar únicamente los personajes más relevantes acorde al promedio de tiempo en pantalla que estos tienen en la muestra seleccionada y la relevancia que estos tienen en el desarrollo y resolución de los conflictos propuestos durante el desarrollo de la trama. La intención, finalmente, es organizar estos datos de manera que el análisis de los mismos pueda ser llevado a cabo apuntando a la resolución de los objetivos propuestos por esta investigación.

\subsubsection{Perfilación de personajes principales}

Tabla 30. Perfil del personaje Harrison.

\begin{tabular}{|c|c|c|c|c|}
\hline \multirow[t]{3}{*}{$\begin{array}{l}\text { PSICOLOGÍA DEL } \\
\text { PERSONAJE }\end{array}$} & \multicolumn{2}{|l|}{$\begin{array}{l}\text { ROL DEL } \\
\text { PERSONAJE }\end{array}$} & \multicolumn{2}{|c|}{$\begin{array}{l}\text { Protagónico - De equilibrio } \\
\text { Temático } \\
\text { Catalizador / Contexto / Confidente }\end{array}$} \\
\hline & \multicolumn{2}{|c|}{ TEMPERAMENTO } & \multicolumn{2}{|c|}{ Tendencia a Flemático } \\
\hline & \multicolumn{2}{|c|}{ PERSONALIDAD } & \multicolumn{2}{|c|}{$\begin{array}{l}\text { Extrovertido, con características Sensitivo } \\
\text { y sentimental. }\end{array}$} \\
\hline \multirow[t]{3}{*}{$\begin{array}{l}\text { ELEMENTOS } \\
\text { SOCIOECONOMICOS }\end{array}$} & \multicolumn{2}{|c|}{$\begin{array}{l}\text { NIVEL } \\
\text { SOCIOECONOMICO }\end{array}$} & \multicolumn{2}{|c|}{ Medio } \\
\hline & \multicolumn{2}{|l|}{ PROFESIÓN } & \multicolumn{2}{|c|}{ Se desconoce } \\
\hline & \multicolumn{2}{|l|}{ EDUCACIÓN } & \multicolumn{2}{|c|}{ Se desconoce } \\
\hline \multirow{8}{*}{$\begin{array}{l}\text { FISIOLOGÍA DEL } \\
\text { PERSONAJE }\end{array}$} & GÉNERO & & dlino & \\
\hline & \multirow{2}{*}{$\begin{array}{l}\text { EXPRESIONES } \\
\text { VERBALES }\end{array}$} & \multirow{2}{*}{\multicolumn{2}{|c|}{\begin{tabular}{|l} 
LENGUAJE \\
ARGOT
\end{tabular}}} & Popular \\
\hline & & & & Juvenil \\
\hline & \multirow[t]{5}{*}{$\begin{array}{l}\text { APARIENCIA } \\
\text { (Indumentaria) }\end{array}$} & \multicolumn{2}{|c|}{ Corte } & Cabello Corto \\
\hline & & \multicolumn{2}{|c|}{ Material } & Cuero / Jean \\
\hline & & \multicolumn{2}{|c|}{ Color(Gamas) } & Negro, Oscuros \\
\hline & & \multicolumn{2}{|c|}{ Accesorios } & Ninguno \\
\hline & & \multicolumn{2}{|c|}{ Estilo } & Informal \\
\hline $\begin{array}{l}\text { IMPORTANCIA DEL } \\
\text { PERSONAJE }\end{array}$ & \multicolumn{4}{|l|}{ Principal } \\
\hline
\end{tabular}


Harrison es el único personaje de toda la serie que no hace presencia física más allá de los primeros 10 minutos del primer capítulo de la misma, sin embargo, es hacia quien los demás integrantes del grupo dirigen sus cartas contándoles las historias que les ocurren durante los diferentes capítulos que componen la serie. Solo podemos acceder al personaje de manera directa durante los 10 minutos anteriormente mencionados, sin embargo, a través de lo que comentan durante los capítulos los otros personajes, se puede establecer una perfilación de lo que representa Harrison y cuál es la posición que este ocupa dentro de las relaciones con los demás jóvenes y personajes adultos. Harrison es reconocido como líder del grupo, por sus condiciones para analizar de manera clara y rápida las situaciones a las que se ven confrontados, la forma positiva en que abordaba las tensiones con Afranio, mostrando un carácter afable, pero a la vez muy serio en la búsqueda de alternativas para el bienestar de todos. Estas características, no solo son reconocidas por el grupo de jóvenes sino que, además, todos los personajes adultos se lo reconocen y añoran volver a contar con un joven de estas características dentro de su entramado social. Harrison, entonces, es el enlace entre la juventud que aun busca su lugar y su posición y una adultez ya establecida y que detenta el poder y el control sobre el manejo de las cosas que ocurren en la comunidad. Por otra parte, se hace interesante revisar cómo funciona el personaje de Harrison como aglutinador de las expectativas y sueños del grupo de jóvenes, en tanto su partida hacia Estados Unidos, en búsqueda del "sueño americano", muestra que esta juventud en particular está en una búsqueda constante de su lugar y de los elementos que puedan dar cuenta de su posición frente a los demás. Desde la perspectiva de Harrison, son los jóvenes quienes deben asumir estos riesgos y estructurarse de una manera en que no se afecten los demás en la búsqueda de estos sueños e ideales. Las cartas que los demás le dirigen, se convierten en pequeños elementos que visualizan más el ideal del joven desde lo que podría ser Harrison que tal vez lo que realmente este sea.

Tabla 31. Perfil del personaje Eric.

\begin{tabular}{|l|l|l|}
\hline $\begin{array}{l}\text { PSICOLOGÍA DEL } \\
\text { PERSONAJE }\end{array}$ & $\begin{array}{l}\text { ROL DEL } \\
\text { PERSONAJE }\end{array}$ & $\begin{array}{l}\text { Protagonista/ } \\
\text { Autoridad/Gracioso } \\
\text { Contraste }\end{array}$ \\
\cline { 2 - 3 } & TEMPERAMENTO & $\begin{array}{l}\text { Colérico } \\
\text { Marcadamente colérico }\end{array}$ \\
\hline & PERSONALIDAD & Extrovertido, Cerebral e Intuitivo
\end{tabular}




\begin{tabular}{|c|c|c|c|}
\hline \multirow[t]{3}{*}{$\begin{array}{l}\text { ELEMENTOS } \\
\text { SOCIOECONOMICOS }\end{array}$} & $\begin{array}{l}\text { NIVEL } \\
\text { SOCIOECONOMICO }\end{array}$ & \multicolumn{2}{|l|}{ Medio } \\
\hline & PROFESIÓN & \multicolumn{2}{|l|}{ Tendero } \\
\hline & EDUCACIÓN & \multicolumn{2}{|c|}{ (Se desconoce) } \\
\hline \multirow{8}{*}{$\begin{array}{l}\text { FISIOLOGÍA DEL } \\
\text { PERSONAJE }\end{array}$} & GÉNERO & \multicolumn{2}{|c|}{ ulino } \\
\hline & \multirow{2}{*}{$\begin{array}{l}\text { EXPRESIONES } \\
\text { VERBALES }\end{array}$} & \multirow{2}{*}{$\begin{array}{l}\text { LENGUAJE } \\
\text { ARGOT }\end{array}$} & Popular \\
\hline & & & Juvenil \\
\hline & \multirow[t]{5}{*}{\begin{tabular}{|l|} 
APARIENCIA \\
(Indumentaria)
\end{tabular}} & Corte & $\begin{array}{l}\text { Cabello Corto/ } \\
\text { Rapado }\end{array}$ \\
\hline & & Material & $\begin{array}{l}\text { Lana, telas } \\
\text { Tela, Paño } \\
\text { Sintéticos } \\
\text { Fríos }\end{array}$ \\
\hline & & Color(Gamas) & Cálidos y Neutros \\
\hline & & Accesorios & No utiliza \\
\hline & & Estilo & Informal \\
\hline $\begin{array}{l}\text { IMPORTANCIA DEL } \\
\text { PERSONAJE }\end{array}$ & \multicolumn{3}{|l|}{$\begin{array}{l}\text { Principal } \\
\text { Secundario }\end{array}$} \\
\hline
\end{tabular}

Dentro de la serie, el personaje de Eric tiene una gran preponderancia en las tramas que se desarrollan en los capítulos de la muestra. Su personaje muestra una dinámica y unas prácticas comunicativas particulares que pueden ser contrastadas con las del personaje de Afranio (adulto antagonista), enriqueciendo el análisis que se puede plantear desde este ejercicio. Eric, es protagonista en la mayor parte de los capítulos de la serie analizados, de temperamento colérico, extrovertido, cerebral e intuitivo. Su nivel socioeconómico, medio, está marcado por el oficio que desempeña según lo que se puede apreciar en la serie (tendero), no se aprecia durante la serie que haya tenido algún tipo de estudio (más allá del secundario). En cuanto su apariencia física, utiliza el cabello muy corto (rapado), con ropa informal, utilizando principalmente colores Fríos y Neutros, aunque no utiliza accesorios. Es importante señalar que Eric, con su lenguaje popular y con gran argot juvenil, es considerado un líder dentro del grupo de jóvenes y constantemente parecía competir este liderazgo con el inexistente Harrison, y en los capítulos de la muestra, con Albeiro. Su actitud está marcada por un pronunciado egoísmo en tanto que, aunque propone soluciones para los diversos problemas que 
afrontan los jóvenes y la misma comunidad, estas soluciones primero conllevan a resolver una necesidad particular del mismo Eric, por tanto, se muestra preocupado, con una alta capacidad de escucha, manipula con su lenguaje y cuida poco que terceros, que estén fuera del circulo de los jóvenes y de los habitantes del barrio, se vean perjudicados por sus acciones. Eric es la representación de una fracción de los jóvenes que busca utilizar los medios que han propuesto aquellos miembros adultos de la comunidad frente a las problemáticas y a la resolución de las mismas, pensando en los beneficios propios y económicos que estos puedan generar para sí. Es el espejo en el que se refleja la continuidad entre lo que es el joven y lo que puede ser el adulto.

Tabla 32. Perfil del personaje Albeiro.

\begin{tabular}{|c|c|c|c|}
\hline \multirow[t]{3}{*}{$\begin{array}{l}\text { PSICOLOGÍA DEL } \\
\text { PERSONAJE }\end{array}$} & ROL DEL PERSONAJE & \multicolumn{2}{|c|}{$\begin{array}{l}\text { Protagónico - De equilibrio } \\
\text { Temático } \\
\text { Catalizador / Contexto / Confidente }\end{array}$} \\
\hline & TEMPERAMENTO & \multicolumn{2}{|c|}{ Tendencia a Flemático } \\
\hline & PERSONALIDAD & \multicolumn{2}{|c|}{$\begin{array}{l}\text { Extrovertido, con características Sensitivo } \\
\text { y sentimental. }\end{array}$} \\
\hline \multirow{3}{*}{$\begin{array}{l}\text { ELEMENTOS } \\
\text { SOCIOECONOMICOS }\end{array}$} & NIVEL SOCIOECONOMICO & \multicolumn{2}{|l|}{ Medio } \\
\hline & PROFESIÓN & \multicolumn{2}{|l|}{ Tendero } \\
\hline & EDUCACIÓN & \multicolumn{2}{|c|}{ (Se desconoce) } \\
\hline \multirow{8}{*}{$\begin{array}{l}\text { FISIOLOGÍA DEL } \\
\text { PERSONAJE }\end{array}$} & GÉNERO & \multicolumn{2}{|l|}{ Masculino } \\
\hline & \multirow{2}{*}{$\begin{array}{l}\text { EXPRESIONES } \\
\text { VERBALES }\end{array}$} & LENGUAJE & Popular \\
\hline & & ARGOT & Juvenil \\
\hline & \multirow{5}{*}{$\begin{array}{l}\text { APARIENCIA } \\
\text { (Indumentaria) }\end{array}$} & \multirow{2}{*}{\begin{tabular}{|l|} 
Corte \\
Material \\
\end{tabular}} & Cabello Largo \\
\hline & & & Lana \\
\hline & & Color(Gamas) & Neutros \\
\hline & & Accesorios & No utiliza \\
\hline & & Estilo & Informal \\
\hline $\begin{array}{l}\text { IMPORTANCIA DEL } \\
\text { PERSONAJE }\end{array}$ & \multicolumn{3}{|l|}{$\begin{array}{l}\text { Principal } \\
\text { Secundario }\end{array}$} \\
\hline
\end{tabular}

Es el hermano de Eric y en un primer momento, se muestra como opuesto a este en muchas de las cosas que representa Eric. Mientras aquel es egoísta, ensimismado y buscador solo del beneficio propio, Albeiro representa el grupo de jóvenes que quieren brindar una alternativa positiva y de construcción no solo para el grupo al que representa 
sino además para la comunidad circundante. Es el joven preocupado por hacer las cosas que puedan brindarle una mejora y hacerlo de buena manera, procurando pensar en todas las alternativas y escogiendo aquella que traiga menos complicaciones para todas aquellas personas involucradas en las situaciones. Las formas comunicativas que utiliza, buscan delimitar claramente las dificultades y brindar alternativas de solución, por lo que es constantemente buscado por otros personajes juveniles para solucionar las situaciones que los afectan, teniéndolo como un personaje ecuánime y que puede brindarle una alternativa clara frente a la situación. Su temperamento es muestra de esto, de tendencia flemática, es mucho más emocional y busca apelar a la emocionalidad que a la razón para resolver sus problemas. Su nivel socioeconómico, medio, está marcada por el oficio que desempeña según lo que se puede apreciar en la serie (tendero), no se aprecia durante la serie que haya tenido algún tipo de estudio (más allá del secundario). Su apariencia física, es contrastante con la de Eric, de cabello largo, apariencia más desenfadada y juvenil si se quiere, utilizando principalmente colores neutros en su vestuario. En cierta forma, este personaje es utilizado para brindar contraste frente a un personaje fuerte y egoísta como Eric, para mostrar además que hay también una tendencia a acercarse a los demás y a solucionar las problemáticas considerando las opciones más adecuadas para ello.

Tabla 33. Perfil del personaje Marisela.

\begin{tabular}{|c|c|c|c|}
\hline \multirow{3}{*}{$\begin{array}{l}\text { PSICOLOGÍA DEL } \\
\text { PERSONAJE }\end{array}$} & ROL DEL PERSONAJE & \multicolumn{2}{|c|}{ Protagónico - De interés romántico } \\
\hline & TEMPERAMENTO & \multicolumn{2}{|c|}{ Tendencia hacia el temperamento colérico } \\
\hline & PERSONALIDAD & \multicolumn{2}{|c|}{$\begin{array}{l}\text { Tendencia a ser Extrovertida, con } \\
\text { características sentimental e intuitiva. }\end{array}$} \\
\hline \multirow{3}{*}{$\begin{array}{l}\text { ELEMENTOS } \\
\text { SOCIOECONOMICOS }\end{array}$} & \multirow{2}{*}{\begin{tabular}{|l} 
NIVEL SOCIOECONOMICO \\
PROFESIÓN
\end{tabular}} & \multicolumn{2}{|c|}{ Medio Alto } \\
\hline & & \multicolumn{2}{|c|}{ Estudiante Universitaria } \\
\hline & EDUCACIÓN & \multicolumn{2}{|c|}{ Bachiller } \\
\hline \multirow{6}{*}{$\begin{array}{l}\text { FISIOLOGÍA DEL } \\
\text { PERSONAJE }\end{array}$} & GÉNERO & \multicolumn{2}{|c|}{ Femenino } \\
\hline & \multirow[t]{2}{*}{$\begin{array}{l}\text { EXPRESIONES } \\
\text { VERBALES }\end{array}$} & LENGUAJE & $\begin{array}{l}\text { Estándar } \\
\text { Popular }\end{array}$ \\
\hline & & ARGOT & Juvenil \\
\hline & \multirow{3}{*}{\begin{tabular}{|l} 
APARIENCIA \\
(Indumentaria)
\end{tabular}} & Corte & Cabello Largo \\
\hline & & Material & $\begin{array}{l}\text { Utiliza Paños y Lanas } \\
\text { Lana }\end{array}$ \\
\hline & & Color(Gamas) & $\begin{array}{l}\text { Cálidos } \\
\text { Neutros }\end{array}$ \\
\hline
\end{tabular}




\begin{tabular}{|l|l|l|l|}
\hline \multirow{2}{*}{} & & Accesorios & $\begin{array}{l}\text { Aretes } \\
\text { No utiliza }\end{array}$ \\
\cline { 3 - 4 } & & Estilo & $\begin{array}{l}\text { Formal } \\
\text { Informal }\end{array}$ \\
\hline $\begin{array}{l}\text { IMPORTANCIA DEL } \\
\text { PERSONAJE }\end{array}$ & $\begin{array}{l}\text { Principal } \\
\text { Secundario }\end{array}$ & \\
\hline
\end{tabular}

Marisela es uno de los personajes femeninos principales de la serie, que sirve para mostrar, en cierta medida, las relaciones de género que se establecen entre los jóvenes y la forma de afrontar los temas que involucran el amor y las acciones que involucran este tipo de relaciones entre ellos Esto se ve particularmente, en su relación a distancia con Harrison y como se relaciona con los hermanos, Eric y Albeiro, quienes en cierta forma también visualizan que la posición del líder conlleva el estar acompañados de Marisela. Marisela es hija del Adulto que representa el antagonista a lo que el grupo construye y desea, y, por tanto, su relación con el grupo es dual, en tanto en muchas ocasiones está de acuerdo con ellos, pero la cercanía con su padre, la hace cuestionar en múltiples ocasiones las actitudes y comportamientos que asumen los demás jóvenes del grupo. Trata de manejar de forma adecuada la tensión que se genera entre ellos y, además, aporta una visión particular del mundo, mucho más estructurada y organizada que el resto de estos. Tiene tendencia a ser extrovertida, con características sensitivas y sentimentales, lo que la hace ser particularmente sensible a las dificultades y problemáticas que se producen en el barrio y que, por lo general, hace que tienda a asumir una posición que en definitiva afecta los intereses de su padre. Su aspecto físico, como es representado en la serie, tiende a ser más clásico en comparación con el resto de personajes jóvenes de la obra, también esto siendo congruente por ser la única que en apariencia logra alcanzar un nivel universitario dentro del grupo de jóvenes, mostrando así una realidad que permanece en los grupos de la juventud en los contextos populares: son muy pocos los que logran acceder a los niveles de la educación superior y la mayoría de ellos permanecen con estudios básicos, técnicos y tecnológicos. Esto a veces le causa diferencias con algunos de los integrantes del grupo quienes la consideran como "consentida" o "gomela" por manejarse y comportarse de forma distinta al resto de los jóvenes. 
Tabla 34. Perfil del personaje Nancy.

\begin{tabular}{|c|c|c|c|}
\hline \multirow[t]{3}{*}{$\begin{array}{l}\text { PSICOLOGÍA DEL } \\
\text { PERSONAJE }\end{array}$} & \multicolumn{2}{|l|}{$\begin{array}{l}\text { ROL DEL } \\
\text { PERSONAJE }\end{array}$} & $\begin{array}{l}\text { Catalizador } \\
\text { Contraste }\end{array}$ \\
\hline & \multicolumn{2}{|l|}{ TEMPERAMENTO } & $\begin{array}{l}\text { Colérico } \\
\text { Sanguíneo }\end{array}$ \\
\hline & \multicolumn{2}{|l|}{ PERSONALIDAD } & $\begin{array}{l}\text { Tendencia a ser Extrovertida, con } \\
\text { características sensitiva y sentimental. }\end{array}$ \\
\hline \multirow{3}{*}{$\begin{array}{l}\text { ELEMENTOS } \\
\text { SOCIOECONOMICOS }\end{array}$} & \multicolumn{3}{|c|}{ NIVEL SOCIOECONOMICOMedio Bajo } \\
\hline & PROFESIÓN & \multicolumn{2}{|c|}{ No presenta datos } \\
\hline & EDUCACIÓN & \multicolumn{2}{|c|}{ No presenta datos } \\
\hline \multirow{8}{*}{$\begin{array}{l}\text { FISIOLOGÍA DEL } \\
\text { PERSONAJE }\end{array}$} & GÉNERO & Femenino & \\
\hline & \multirow{2}{*}{$\begin{array}{l}\text { EXPRESIONES } \\
\text { VERBALES }\end{array}$} & LENGUAJE & Popular \\
\hline & & ARGOT & Juvenil \\
\hline & \multirow{5}{*}{\begin{tabular}{|l} 
APARIENCIA \\
(Indumentaria)
\end{tabular}} & Corte & Cabello Largo \\
\hline & & Material & \begin{tabular}{|l|} 
Telas y Lanas \\
Tela, Cuero, Lana
\end{tabular} \\
\hline & & Color(Gamas) & $\begin{array}{l}\text { Fríos } \\
\text { Neutros }\end{array}$ \\
\hline & & Accesorios & \begin{tabular}{|l|} 
Collares \\
No utiliza
\end{tabular} \\
\hline & & Estilo & Informal \\
\hline $\begin{array}{l}\text { IMPORTANCIA DEL } \\
\text { PERSONAJE }\end{array}$ & \multicolumn{3}{|l|}{ Secundario } \\
\hline
\end{tabular}

Nancy es otro de los personajes femeninos de la serie, que muestra una posición opuesta a lo que representa Marisela. Nancy no es una mujer muy estudiada, está más interesada en la música y los movimientos alternativos, es desenfadada en el trato y en la manera de relacionarse con las demás personas. Desde lo que se presenta en la muestra seleccionada de la serie, es una persona que ha tenido malas experiencias sentimentales, mostrando así que la juventud no solo tiene experiencias positivas frente a este tema, sino que, además, puede llegar a ser marcada por el mismo.

Su lenguaje es pueril para lo que los demás personajes presentan y representa una mujer joven fuerte e independiente, que solo busca el bienestar de todos y que cree en la igualdad ante todas las cosas, incluyendo el disminuir la visión de la mujer como el sexo débil, visualizándose a sí misma como una mujer capaz y que no necesita de nadie para poder subsistir. Representa, entonces, a la nueva juventud que surge después del largo 
camino recorrido por los movimientos sociales juveniles que buscan la liberación y el acceso de la juventud a todos los niveles y que la igualdad a todo nivel es posible.

La música y el arte son parte fundamentales de la identidad de Nancy y que sirve como contraste para lo que se muestra de las mujeres jóvenes en personajes como Marisela o Mireya. En Nancy, la estética juega un papel definitorio en lo que corresponde a su identidad y su posición ética frente a la realidad circundante, haciendo de ello una postura congruente con su actitud frente a la vida y a la manera de abordar los problemas: desenfadada, principalmente, asociados a elementos característicos del rock, como ropas negras y colores negros, además, de no identificarse con el rol característico de las mujeres, al no utilizar ropas ajustadas o que enseñen demasiado de ella. Se descubre así, un personaje característico que puede llegar a caer en las simplificaciones y clichés impuestos desde afuera por los adultos que la observan, al relacionar su actitud y el manejo de sus realidades con las apuestas estéticas - ideológicas de subculturas asociadas al rock. Su postura, entonces, puede ser asociada con una estética que busca romper más que integrarse a un esquema predeterminado por una adultez preexistente en el entorno. Es muy extrovertida en el trato y su lenguaje puede a llegar a ser muy pueril.

Tabla 35. Perfil del personaje Nacho.

\begin{tabular}{|c|c|c|c|}
\hline \multirow[t]{3}{*}{$\begin{array}{l}\text { PSICOLOGÍA DEL } \\
\text { PERSONAJE }\end{array}$} & \multicolumn{2}{|l|}{$\begin{array}{l}\text { ROL DEL } \\
\text { PERSONAJE }\end{array}$} & Temático \\
\hline & \multicolumn{2}{|l|}{ TEMPERAMENTO } & Tendencia a flemático \\
\hline & PERSONALIDAD & \multicolumn{2}{|c|}{$\begin{array}{l}\text { Tendencia a Introvertido, con } \\
\text { características: sensitivo y sentimental }\end{array}$} \\
\hline \multirow[t]{3}{*}{$\begin{array}{l}\text { ELEMENTOS } \\
\text { SOCIOECONOMICOS }\end{array}$} & \multicolumn{2}{|c|}{$\begin{array}{l}\text { NIVEL } \\
\text { SOCIOECONOMICO }\end{array}$} & Medio \\
\hline & \multicolumn{2}{|l|}{ PROFESIÓN } & (Se desconoce) \\
\hline & \multicolumn{2}{|l|}{ EDUCACIÓN } & (Se desconoce) \\
\hline \multirow{5}{*}{$\begin{array}{l}\text { FISIOLOGÍA DEL } \\
\text { PERSONAJE }\end{array}$} & GÉNERO & Masculino & \\
\hline & \multirow{2}{*}{$\begin{array}{l}\text { EXPRESIONES } \\
\text { VERBALES }\end{array}$} & LENGUAJE & Popular \\
\hline & & ARGOT & Juvenil \\
\hline & \multirow{2}{*}{$\begin{array}{l}\text { APARIENCIA } \\
\text { (Indumentaria) }\end{array}$} & Corte & Cabello Largo \\
\hline & & Material & Lana \\
\hline
\end{tabular}




\begin{tabular}{|l|l|l|l|}
\hline & & Color(Gamas) & Neutros \\
\cline { 3 - 4 } & & Accesorios & No utiliza \\
\cline { 3 - 4 } & & Estilo & Informal \\
\hline $\begin{array}{l}\text { IMPORTANCIA DEL } \\
\text { PERSONAJE }\end{array}$ & Secundario & \\
\hline
\end{tabular}

Nacho es un joven cercano a la representación que hace Nancy de la juventud desenfadada, con una estética con cabello largo y colores similares a lo que se utiliza en el rock. También sirve de apoyo a esa juventud resultado de los procesos de cambio social a los que fue sometida durante los años anteriores, con los movimientos sociales juveniles transversalizados por el arte y la música. Su actitud, por lo general, está enmarcada en un accionar más hacia el apoyo de alternativas planteadas por los demás, que ser quien propone las alternativas de solución frente a las dinámicas a las que se ven confrontados. Tiende a ser introvertido, siendo sensitivo y sentimental, lo que lo hace ser mucho más sensible ante las necesidades del entorno que lo rodea, por lo que se siente particularmente perturbado cuando ve que se está cometiendo alguna injusticia ya sea contra alguno de los compañeros de su grupo, o contra alguno de los miembros de la comunidad. Su principal característica está enmarcada en este sentido de servicio y apoyo tanto a su grupo como a los demás. Otra juventud representada en Nacho, aquella que se preocupa por las injusticias que se cometen alrededor, pero, aunque no asume posiciones de liderazgo y de resolución de conflictos proactiva, está ahí para ayudar a resolver las problemáticas desde lo que proponen otros que consideran tienen soluciones efectivas frente a estas situaciones.

Tabla 36. Perfil del personaje Lalo.

\begin{tabular}{|l|l|l|}
\hline $\begin{array}{l}\text { PSICOLOGÍA DEL } \\
\text { PERSONAJE }\end{array}$ & $\begin{array}{l}\text { ROL DEL } \\
\text { PERSONAJE }\end{array}$ & $\begin{array}{l}\text { Gracioso } \\
\text { Temático }\end{array}$ \\
\cline { 2 - 3 } & TEMPERAMENTO & Tendencia a Sanguíneo \\
\cline { 2 - 3 } & PERSONALIDAD & $\begin{array}{l}\text { Extrovertido, con características: sensitivo } \\
\text { e intuitivo. }\end{array}$ \\
\hline $\begin{array}{l}\text { ELEMENTOS } \\
\text { SOCIOECONOMICOS }\end{array}$ & $\begin{array}{l}\text { NIVEL } \\
\text { SOCIOECONOMICO }\end{array}$ & Medio \\
\cline { 2 - 3 } & PROFESIÓN & $\begin{array}{l}\text { Mantenimiento } \\
\text { Técnico }\end{array}$ \\
& &
\end{tabular}




\begin{tabular}{|c|c|c|c|}
\hline & EDUCACIÓN & \multicolumn{2}{|c|}{ (Se desconoce) } \\
\hline \multirow{8}{*}{$\begin{array}{l}\text { FISIOLOGÍA DEL } \\
\text { PERSONAJE }\end{array}$} & GÉNERO & \multicolumn{2}{|l|}{ Masculino } \\
\hline & EXPRESIONES & LENGUAJE & Popular/vulgar \\
\hline & VERBALES & ARGOT & Juvenil \\
\hline & APARIENCIA & Corte & Cabello Corto \\
\hline & & Material & $\begin{array}{l}\text { Lana y Tela } \\
\text { Telas }\end{array}$ \\
\hline & & Color(Gamas) & \begin{tabular}{|l|} 
Cálidos \\
Básicos y neutros
\end{tabular} \\
\hline & & Accesorios & No utiliza \\
\hline & & Estilo & Informal \\
\hline $\begin{array}{l}\text { IMPORTANCIA DEL } \\
\text { PERSONAJE }\end{array}$ & \multicolumn{3}{|l|}{$\begin{array}{l}\text { Secundario } \\
\text { Principal }\end{array}$} \\
\hline
\end{tabular}

Lalo es el personaje lleno de humor y que es un excelente amigo de alguien como Eric, aunque este no valore adecuadamente lo que Lalo hace por él. Es trabajador, un "todero", lo que representa una juventud que no se deja amilanar frente a las dificultades de la vida y son "echados para adelante". Enamoradizo, buscador del afecto de Mireya, y que no tiene restricciones a la hora de apoyar a su grupo (incluso prestándose para distraer a Graciela de una información que no debía ser compartida con Afranio), Lalo conlleva en si la amistad como fuente de definición de una identidad. Se relaciona con un esquema particular de ser joven en el país, en tanto muestra al joven de estrato medio bajo, que no concluyo sus estudios, pero que, aun así, logra ubicarse laboralmente y quiere lo mejor para los suyos y la comunidad que lo rodea. Su estilo es informal, pero puede adoptar fácilmente un estilo formal si la situación lo amerita, mostrando así que es posible la adaptación frente a las dificultades que el medio plantea. Su lenguaje es claro, popular y en ocasiones, algo pueril frente a lo que los demás personajes de la obra audiovisual presentan. Como personaje secundario, más que brindar contexto, generalmente, su papel sirve para alimentar las temáticas que se presentan en los capítulos analizados en esta muestra. 
Tabla 37. Perfil del personaje Randy.

\begin{tabular}{|c|c|c|c|}
\hline \multirow[t]{3}{*}{$\begin{array}{l}\text { PSICOLOGÍA DEL } \\
\text { PERSONAJE }\end{array}$} & $\begin{array}{l}\text { ROL DEL } \\
\text { PERSONAJE }\end{array}$ & \multicolumn{2}{|c|}{$\begin{array}{l}\text { Catalizador } \\
\text { Protagonista }\end{array}$} \\
\hline & TEMPERAMENTO & \multicolumn{2}{|c|}{$\begin{array}{l}\text { Flemático } \\
\text { Tendencia a Sanguíneo }\end{array}$} \\
\hline & PERSONALIDAD & \multicolumn{2}{|c|}{ Introvertido, Cerebral e Intuitivo } \\
\hline \multirow[t]{3}{*}{$\begin{array}{l}\text { ELEMENTOS } \\
\text { SOCIOECONOMICOS }\end{array}$} & $\begin{array}{l}\text { NIVEL } \\
\text { SOCIOECONOMICO }\end{array}$ & \multicolumn{2}{|l|}{ Media } \\
\hline & PROFESIÓN & \multicolumn{2}{|c|}{$\begin{array}{l}\text { Electricista } \\
\text { Mantenimiento }\end{array}$} \\
\hline & EDUCACIÓN & \multicolumn{2}{|c|}{$\begin{array}{l}\text { Técnica } \\
\text { Técnica - Tecnológica }\end{array}$} \\
\hline \multirow{8}{*}{$\begin{array}{l}\text { FISIOLOGÍA DEL } \\
\text { PERSONAJE }\end{array}$} & GÉNERO & Masculino & \\
\hline & \multirow{2}{*}{$\begin{array}{l}\text { EXPRESIONES } \\
\text { VERBALES }\end{array}$} & LENGUAJE & $\begin{array}{l}\text { Estándar } \\
\text { Popular }\end{array}$ \\
\hline & & ARGOT & $\begin{array}{l}\text { Propio } \\
\text { Juvenil }\end{array}$ \\
\hline & \multirow{5}{*}{$\begin{array}{l}\text { APARIENCIA } \\
\text { (Indumentaria) }\end{array}$} & Corte & Cabello Corto \\
\hline & & Material & $\begin{array}{l}\text { Lanas - Telas } \\
\text { Lana }\end{array}$ \\
\hline & & Color(Gamas) & \begin{tabular}{|l|} 
Básicos \\
Neutros \\
Cálidos
\end{tabular} \\
\hline & & Accesorios & No utiliza \\
\hline & & Estilo & $\begin{array}{l}\text { Básico } \\
\text { Informal }\end{array}$ \\
\hline $\begin{array}{l}\text { IMPORTANCIA DEL } \\
\text { PERSONAJE }\end{array}$ & \multicolumn{3}{|l|}{ Secundario } \\
\hline
\end{tabular}

Randy es otro personaje que representa otro tipo de juventud en la obra audiovisual. Es el joven creativo, sensible y que espera mucho de los demás. No es particularmente dado a participar y a intervenir en la resolución de los conflictos, sin embargo, hasta en dos oportunidades toma la dirección y decide solucionar los problemas de la mejor manera en que él considera. Su falta de habilidades sociales, lo lleva muchas veces a actuar de manera romántica e ingenua, planteando así que la juventud también puede tener estas características y que, aun así, pueden aportan a un grupo dinámico y plural en la resolución de los conflictos que le atañen. Su estilo es muy clásico y conservador, aunque no por que pretenda imitar a los adultos que se encuentran en la comunidad circundante sino precisamente, por brindar un aspecto diferenciador frente al resto de 
jóvenes del grupo. Tiende a poseer un lenguaje ligeramente más elevado que los demás, y es aquel quien tiene conocimientos técnicos suficientes para acometer la construcción de elementos tecnológicos que terminan reflejados en el acceso a tecnologías que no eran de muy frecuente acceso para los jóvenes en la época en la que se produjo la serie, a pesar de ser tecnologías ya familiares para ellos (como la radio y la TV). Sus motivaciones son principalmente sus amigos y su familia, representada en Andy, quien es el único personaje que muestran de la familia de Randy durante los episodios seleccionados en la serie.

Tabla 38. Perfil del personaje Mireya.

\begin{tabular}{|c|c|c|c|}
\hline \multirow[t]{3}{*}{$\begin{array}{l}\text { PSICOLOGÍA DEL } \\
\text { PERSONAJE }\end{array}$} & $\begin{array}{l}\text { ROL DEL } \\
\text { PERSONAJE }\end{array}$ & \multicolumn{2}{|c|}{ Temático } \\
\hline & TEMPERAMENTO & \multicolumn{2}{|c|}{ Sanguíneo } \\
\hline & PERSONALIDAD & \multicolumn{2}{|c|}{ Extrovertida, Sensitiva y Sentimental } \\
\hline \multirow[t]{3}{*}{$\begin{array}{l}\text { ELEMENTOS } \\
\text { SOCIOECONOMICOS }\end{array}$} & $\begin{array}{l}\text { NIVEL } \\
\text { SOCIOECONOMICO }\end{array}$ & \multicolumn{2}{|c|}{ Medio Bajo } \\
\hline & PROFESIÓN & \multicolumn{2}{|c|}{ (no registra) } \\
\hline & EDUCACIÓN & \multicolumn{2}{|c|}{ (no registra) } \\
\hline \multirow{8}{*}{$\begin{array}{l}\text { FISIOLOGÍA DEL } \\
\text { PERSONAJE }\end{array}$} & GÉNERO & Femenino & \\
\hline & \multirow{2}{*}{$\begin{array}{l}\text { EXPRESIONES } \\
\text { VERBALES }\end{array}$} & LENGUAJE & Popular \\
\hline & & ARGOT & Juvenil \\
\hline & \multirow{5}{*}{$\begin{array}{l}\text { APARIENCIA } \\
\text { (Indumentaria) }\end{array}$} & Corte & Cabello Largo \\
\hline & & Material & Telas y Lanas \\
\hline & & Color(Gamas) & $\begin{array}{l}\text { Fuertes } \\
\text { Neutros }\end{array}$ \\
\hline & & Accesorios & Ninguno \\
\hline & & Estilo & |lnformal \\
\hline $\begin{array}{l}\text { IMPORTANCIA DEL } \\
\text { PERSONAJE }\end{array}$ & \multicolumn{3}{|l|}{ Secundario } \\
\hline
\end{tabular}

Mireya es el tercer personaje femenino juvenil de la serie, quien presenta una alternativa distinta a lo que muestran tanto Marisela como Nancy. Mireya es una joven atractiva, quien es consciente de este hecho, y está en contacto y acepta su sexualidad de manera 
abierta y sin mayores traumatismos, aunque eso también la convierta en ocasiones en blanco de burlas por parte de las otras mujeres jóvenes del grupo, por su aparente ingenuidad y falta de autorregulación. Mireya muestra la juventud que se encuentra más en contacto con la sexualidad como medio de relacionarse con los demás, pero que, aun así, considera importante que exista un componente afectivo que transversalice las relaciones interpersonales que estos manejen. Su actitud es desenfadada y busca principalmente ser el centro de las miradas y la atención de los muchachos con los que llega a tener contacto durante el transcurso de la obra audiovisual. Mireya, se fija en Lalo porque reconoce en el ese hombre luchador y "echado para adelante" que muchas mujeres buscan para compartir su vida, pero, además, admira la capacidad sensible que posee Randy y en algún momento, llego a tener algo con Harrison y con Eric. No tiene reparo en hablar sobre estas situaciones con los demás. Su estilo y la moda que utiliza es bastante informal, con ropas generalmente ajustadas y que permitan observar sus formas atractivas, de forma llamativa, que atraiga las miradas. Utiliza colores fuertes y neutros para acrecentar esta percepción de sí misma. Su lenguaje es más bien básico y no demasiado elaborado y sirve más como personaje de contexto y temático, que para llevar el peso dramático de la temática de algún capitulo.

Tabla 39. Perfil del personaje Afranio.

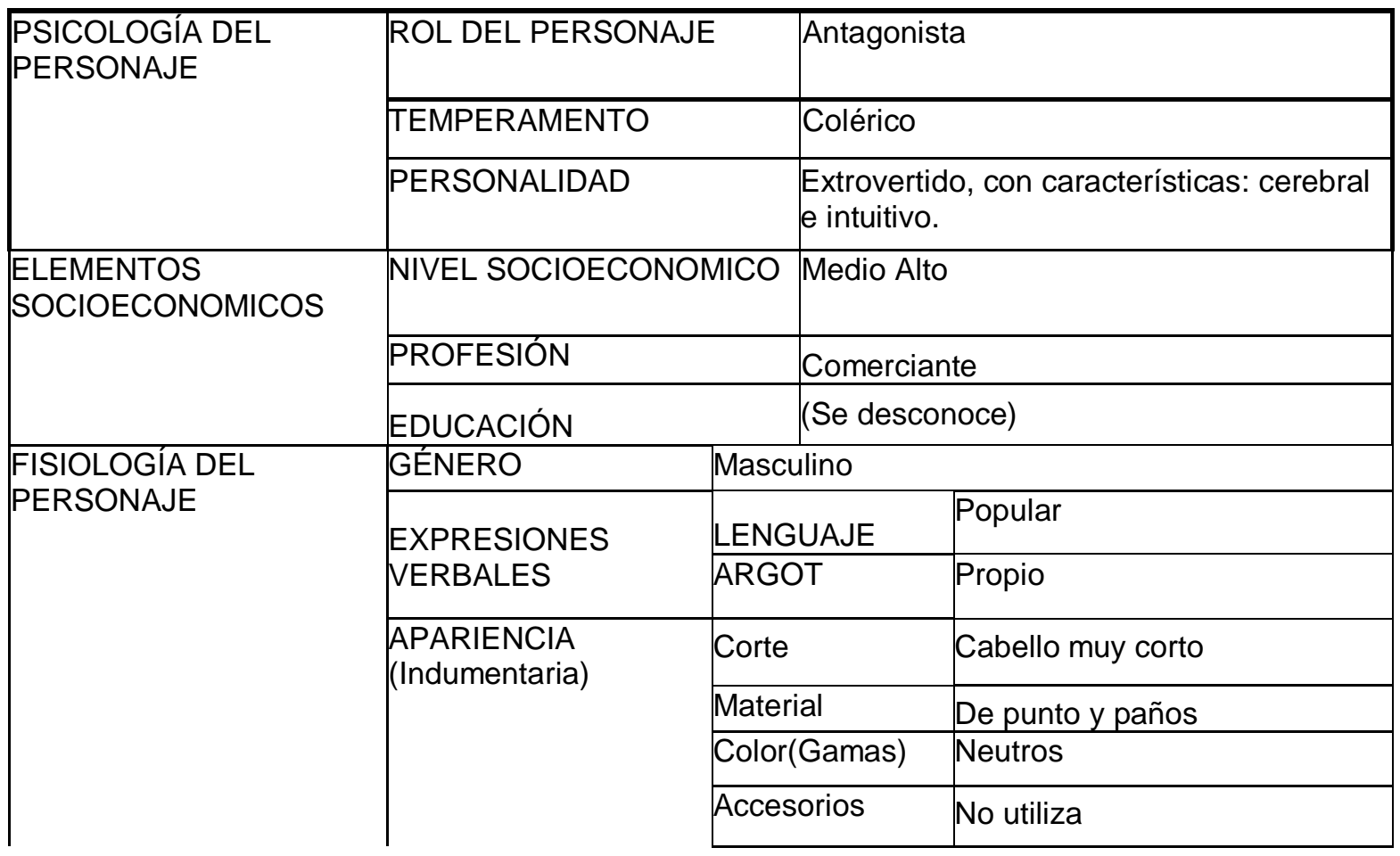




\begin{tabular}{|c|c|c|c|}
\hline & & Estilo & Formal \\
\hline $\begin{array}{l}\text { IMPORTANCIA DEL } \\
\text { PERSONAJE }\end{array}$ & Principal / Antagonista & & \\
\hline
\end{tabular}

Se incluye Afranio en este resumen general de personajes principales, toda vez que es el personaje adulto que sirve de contraste a los jóvenes que se presentan en la obra. Afranio es un personaje extrovertido, cerebral, altamente calculador y que solamente busca tener beneficios para sí mismo, sin importar lo que tenga que hacer o a quien perjudique en el proceso. Es extremadamente conservador, y visualiza a la juventud como un problema que se debe resolver y como vagos o personas que solo están ahí para brindar líos y estorbar frente a lo que él propone. Es uno de los personajes con mejor estatus socioeconómico de todos los que se presentan en la obra audiovisual, sin embargo, no se podría decir que es rico. Básicamente, pertenece a la clase media alta y tiene incidencia en la vida económica y social del barrio con todo aquello en lo que invierte y trabaja para conseguir más cosas para él y su familia (su hija Marisela). Su aspecto, aunque algo descuidado, tiende a ser más tradicional y a hacer contraste en referencia a lo que muestran los jóvenes. Su temperamento es mayormente extrovertido, con características cerebral e intuitivo lo que lo convierte en un personaje frio y calculador. Brinda un excelente contexto al grupo de jóvenes del cual hace parte su hija, pese a lo cual, no tiene ningún tipo de reparo para enfrentarse a estos y servir como antagonista en la totalidad de las narrativas planteadas en la muestra seleccionada para esta investigación. Afranio es la vida adulta que no acepta y no incluye a la juventud como una posibilidad y que, por el contrario, los rechaza y busca las estrategias para excluirlos del devenir de la comunidad y de sus posibilidades para las transformaciones sociales y culturales que estos necesiten.

\subsubsection{Categorías emergentes a partir del análisis}

Después de la caracterización y perfilación de los principales personajes que hacen parte de la serie y que dan cuenta de una manera particular de entender la juventud y las relaciones que se establecen entre este grupo y el grupo de los adultos que rodean el 
devenir de los jóvenes en el ambiente del barrio y de las problemáticas que los movilizan, surge la necesidad de explorar aquellas categorías que emergen de la revisión de aquello que se recopilo de la visualización de los capítulos y la estructuración misma de los perfiles y características de los personajes. A partir de este ejercicio, surgen tres elementos de categorización importantes y que serán elementos de referencia para los posteriores desarrollos en la discusión planteada en este documento investigativo. Estos elementos serían el reconocimiento del joven como agente de transformación y cambio social, La cohesión de grupo como constructor de identidad y, finalmente, la tensión social entre grupos intergeneracionales.

La primera categoría que surge a partir de los datos encontrados se enmarca en el reconocimiento del joven como agente de transformación y cambio social. Para la que se plantea en los capítulos analizados, los jóvenes cumplen un rol como agentes que lideran los cambios que la comunidad necesita y demanda, incluso muchas veces en contraposición a lo que los jóvenes eventualmente necesitan del medio. Desde el documento que aparece referenciado en la página web "Voices of Youth" de la Unicef titulado “¿Qué es un agente de cambio?”, el autor Ruiz Madera (2012), plantea elementos del agente de cambio como aquel que asume un liderazgo, una capacidad para comunicar, hacer una lectura de realidad y una divulgación de la misma distinta a lo que se puede encontrar en la comunidad o en la sociedad circundante que rodea al agente de cambio, una insatisfacción con la realidad en la que se halla inmerso, la asunción de la responsabilidad de los cambios que se requieren en el entorno, una capacidad para inspirar a los demás a aportar elementos desde su visión que construyan los cambios que se necesitan para mejorar las condiciones sociales, en definitiva, que el grupo lidere y facilite el cambio que se requiere para acceder a nuevas y distintas realidades a lo que se ha venido llevando hasta el momento entre la comunidad que circunda al grupo. En los capítulos analizados, son múltiples las ocasiones en que los jóvenes son representados como agentes de transformación y cambio social, en algunas ocasiones oponiéndose a aquello que consideran representa un perjuicio para ellos mismos, pero más frecuentemente, para la comunidad, incluso si esto representa para el grupo la posibilidad de tener confrontaciones al interior del grupo que podrían debilitar su cohesión. 
Los agentes de transformación y cambio social se ven en muchas ocasiones obligados, por su mismo papel, a confrontarse con los poderes dominantes y que detentan la capacidad de mantener el devenir de los pueblos y las comunidades hacia un mismo sentido que, por lo general, propician y generan beneficios solo a sus propios intereses. Como se puede observar en la visualización de las narrativas de los capítulos, esto es claramente representando en la constante confrontación entre los jóvenes y aquel adulto que ostenta una posición de poder dentro de la comunidad y que estigmatiza y segrega al joven como mecanismo para debilitar los posibles elementos de transformación con los que estos cuentan. Es, entonces, que la juventud funciona como aglutinador de los elementos necesarios para la transformación a partir del conflicto social e intergeneracional, no solo generando procesos para su propio beneficio sino que en el camino logran aunar esfuerzos con miembros de otros grupos sociales que no se logran identificar con ellos y que por demás, harían parte de un posible grupo de contraposición pero que terminan beneficiando los esfuerzos del joven para ser en realidad una fuente de cambio para la comunidad.

Es en el ejercicio de sus derechos y deberes no normativos como grupo social, cuando se brinda un reconocimiento de la importancia de los jóvenes en las dinámicas particulares de la comunidad y que los convierten en agentes capaces y suficientes para generar una transformación y cambio social. En este punto, es importante reconocer que estos logran generar liderazgos, procesos de comunicación, actitudes y valores proactivos que potencian las soluciones a los conflictos a los que se enfrentan para apoyar los cambios que necesita la comunidad para su propio beneficio.

Como segunda categoría que emerge del análisis de la información recogida durante la visualización, aparece la cohesión social como constructor de identidad. Hay diversos aspectos a ser mencionados y tratados. Por un lado, las características particulares y personales de cada uno de los personajes jóvenes en la obra, solo se vuelven relevantes en la relación con los demás personajes y cobran importancia en los desarrollos de las tramas planteadas en los capítulos solamente en función de lo que representan para el grupo que conforman los mismos jóvenes. 
La cohesión social es una dinámica que ha sido estudiada desde distintas perspectivas, siendo interesante la definición entregada por el programa URB-AL III: "Una comunidad socialmente cohesionada -cualquiera que sea su escala: local, regional, nacionalsupone una situación global en la que los ciudadanos comparten un sentido de pertenencia e inclusión, participan activamente en los asuntos públicos, reconocen y toleran las diferencias, y gozan de una equidad relativa en el acceso a los bienes y servicios públicos y en cuanto a la distribución del ingreso y la riqueza. Todo ello, en un ambiente donde las instituciones generan confianza y legitimidad y la ciudadanía se ejerce a plenitud", en tanto plantea algunos requisitos para hablar de que un grupo social esta cohesionado. En lo encontrado en el análisis, esta cohesión es particularmente visibilizada en el subgrupo de los jóvenes y estos, a su vez, movilizan a otros subgrupos que no comparten características identitarias con ellos hacia la consecución de una relativa homogenización social y cultural en el entorno del barrio, con vista a ser justos y equitativos en el acceso a los recursos y el bienestar general de la comunidad misma.

Desde aquí, es posible también visualizar como la identidad particular juvenil encuentra sentido en este entramado que apunta a la cohesión social. Solamente en un contexto en el cual la cohesión de grupo estuviese presente, se podría concebir el liderazgo de un personaje como Eric dentro de la obra audiovisual, en tanto sus acciones están impulsadas más por la búsqueda del beneficio propio y el bienestar personal que por el real interés de apoyar los procesos de transformación de la comunidad, sin embargo, es posible entender este liderazgo contrastado con las maneras y las acciones de los otros personajes que pertenecen al grupo, lo cual brinda contraste y contexto al accionar de Eric y permite visualizar sus acciones como parte de un entramado mucho más rico y complejo en donde la cohesión del grupo tiene preponderancia.

De igual forma, personajes que en apariencia no tienen mayor relevancia dentro de la historia, tales como Mireya o Randy, sus formas particulares y su identidad dotan de sentido al grupo y le brindan una alternativa frente a la comunidad que los rodea, generando procesos de empatía e identificación aun cuando no se busquen o no sean percibidos en un primer momento. De esta manera, no solo brindan cohesión interna, sino que facilitan la cohesión con otros subgrupos y, a través de este ejercicio, se 
reafirma la identidad personal en tanto esta se hace importante frente a las necesidades mismas del grupo y de la comunidad en la cual se movilizan.

En un tercer hilo, se encuentra la manera en que se representa la tensión social entre los diferentes grupos intergeneracionales bajo un mismo contexto. En los diferentes elementos narrativos que conforman las temáticas de los capítulos, se evidencia la aparición de elementos de tensión social entre distintos grupos generacionales, sin embargo, esta tensión social puede ser entendida desde los dos polos del espectro: en ocasiones, la tensión es positiva y conduce a la resolución de conflictos en la comunidad y en otros momentos, la tensión es negativa, sirviendo como catalizador para la generación de conflictos que conducen las temáticas presentadas durante los capítulos, de tal manera se evidencia que no necesariamente las tensiones sociales entre grupos intergeneracionales se presentan en una dinámica de choque continuo, sino que es posible la tensión social positiva y constructora.

Los núcleos de tensión social entre grupos generacionales están particularmente presentes en capítulos como Radio Lora (caps. 2 y 3 de la muestra) y Mahatma Randhi (cap. 4 de la muestra), en donde tanto los adultos presentes en estos episodios asumen posiciones cercanas o contrarias a las que plantean el grupo de jóvenes y que en determinados casos, pueden servir como una forma de acrecentar o disminuir los conflictos que se generan en el entramado de la narrativa que se presenta en el capítulo visualizado. Los elementos de apoyo o de confrontación hacia la posición y actitud que asumen los jóvenes durante el transcurso de los temas desarrollados en el capítulo, dan cuenta de una tensión social que puede ser resuelta, como ya se mencionó, de forma positiva (brindando resolución efectiva de las problemáticas) o de forma negativa (incrementando la percepción de los jóvenes como generadores de conflicto y poco conscientes de las necesidades de la comunidad).

Hay otros elementos de análisis que son plausibles de ser abordados en este tercer hilo, tales como la presencia o no de instituciones sociales reguladoras, la relación comunicativa entre los distintos grupos generacionales y la influencia del territorio sobre la relación intergeneracional. 
En nuestra serie estudiada, las instituciones sociales que tienen una función reguladora de la función social del joven como individuo, tales como la escuela, la iglesia, los institutos gubernamentales de acción social, no se encuentran presentes y solamente son mencionados de forma providencial en el desarrollo de los capítulos. En la serie, la relación entre adultos y jóvenes no se encuentra mediada por una institución que los aglutine con reglas y normas de comportamientos específicos y particulares y que beneficien a alguno de los dos grupos presentes en la serie. Aquí, no es una relación reglamentada e interferida por la presencia de una macro estructura institucional, ni siquiera la familia como institución tiene un peso importante en la relación establecida en tanto la mayoría de los jóvenes se muestran de manera autónoma e independiente de un núcleo familiar, aunque en los primeros capítulos de la muestra analizada, es posible observar una ligera injerencia de adultos familiares a los protagonistas jóvenes de nuestra serie (la madre de Albeiro y Eric, el padre de Marisela), pero no direcciona todo el accionar, las posturas y actitudes de los jóvenes frente a las situaciones.

En cuanto a la comunicación de los distintos miembros de los grupos generacionales, es una comunicación dinámica, incluso con aquellos personajes que representan una tensión negativa en la relación establecida. Se presenta de manera clara y directa las diversas posiciones que se asumen, facilitando los procesos tanto de acercamiento como los de confrontación. Sin embargo, en un capitulo como "Mahatma Randhi", la posición de uno de los personajes juveniles es manipulada desde las creencias culturales de la comunidad adulta presente y se transforma en fuente de malinterpretación de las intencionalidades de este, generando una situación conflictiva que solo se logra resolver en la medida en que este mismo personaje decide retirarse de la actividad que estaba realizando como medio de protesta frente a otra situación que perjudicaba a la comunidad y en particular, a su hermano menor. El sentido del mensaje que quiso enviar se perdió en el camino de la dinámica social intergeneracional, mostrando como esta no solo depende de los canales y los medios utilizados para comunicarse, sino que además las creencias y los elementos culturales influyen en la relación comunicacional entre los grupos intergeneracionales. 
Por último, el barrio como territorio al cual tienen acceso tanto adultos como jóvenes se presenta como la principal influencia de las narrativas y los conflictos que sobre él se construyen. Tal vez las dinámicas serian distintas y diferentes si no se hubiesen desarrollado en un ambiente menos regulado e institucionalizado como lo es el barrio. Las características que de este nos muestra la serie, nos permite acercarnos a un territorio homogéneo, con elementos claramente reconocibles como la tienda, en donde se aglutine la masa social de la comunidad, el parque, en donde muchas veces son los jóvenes quienes se reúnen y definen cursos de acción frente a las situaciones, las calles del barrio mismo, en donde en algunas ocasiones transcurre la acción de la narrativa serializada. Es en este entorno, en donde se pueden comprender las actitudes de oposición a una fuerza dominante como la que representa Afranio para la comunidad, quien no cuenta con demasiados medios institucionales para defender sus intereses frente a la presión liderada por el grupo de jóvenes y que aglutina al resto de adultos que se alinean con las propuestas de los jóvenes. Es en el barrio, el territorio en donde se construyen las amistades y se cimientan las identidades particulares de cada uno de los personajes juveniles presentes en la obra. 


\section{Capítulo 4. Discusión}

Para adelantar el proceso de discusión, se retomará lo planteado al inicio de esta investigación con el objetivo y las preguntas orientadoras que dieron orden y sentido al proceso investigativo, y se procederá a establecer un dialogo entre los autores explorados que brindan información sobre los referentes investigados y se hará contraste con lo encontrado durante la recolección de información, la estructuración de los datos y el análisis de los mismos.

Desde su objetivo, esta investigación se centró en analizar los elementos estéticos y de construcción de perfil que dan cuenta de una representación mediática de la condición de ser joven, en su identidad y posición sociocultural en el entorno ficcional producido y transmitido en los contenidos de la serie cartas a Harrison.

A partir del análisis de la información obtenida en la visualización de los capítulos de la muestra seleccionada, se pudieron identificar diferentes componentes que dan respuesta a la manera como los jóvenes son representados en sus estéticas y modas, la forma como interpretan el mundo, la función que cumplen en él, las acciones que desarrollan y el modo en que interactúan con las personas presentes en el conglomerado social que transversaliza el entorno ficcional.

En la relación que se puede establecer a partir de estos resultados, se pueden desarrollar diferentes discusiones en confrontación con el camino teórico recorrido durante el transcurso de esta investigación. Para guiar y orientar esta discusión, se partirá de los objetivos específicos que se establecieron para ampliar y profundizar los alcances del objetivo general planteado para abordar la problemática de la representación de la juventud en la serie televisiva "Cartas a Harrison", básicamente en tres referentes: 1. Los elementos característicos de los perfiles de los personajes, en cuanto su moda, personalidad, tipologías, contexto socioeconómico y la importancia de estos en la trama de la serie. 2. Las actitudes y valores que se puedan encontrar en los 
contenidos de la serie alrededor de los jóvenes y el contexto en el que estos se movilizan como grupo social relevante y, 3. La manera en que se presentan las tensiones entre los personajes jóvenes y los personajes adultos de la serie, además de la manera en que se resuelven los conflictos resultantes de tales tensiones, particularmente, la actuación de los jóvenes frente a ellos.

Para empezar, al hacer una revisión de los resultados arrojados por la visualización y la organización de los datos disponibles con sus respectivos análisis, es posible afirmar que esta serie, plantea una posición intermedia en cuanto a la estética particular del joven en contraste con la estética del adulto en la serie, intermedia en tanto algunos elementos como el uso del cabello largo o el de chaquetas de cuero en alguno de los personajes brindan una señal inequívoca que nos encontramos ante una manera de fijar una posición y de presentar una identidad que lo diferencia del otro, en especial, del otro adulto. Sin embargo, dentro del mismo grupo de jóvenes, también se presenta una tendencia que mantiene un canon estético más en sintonía con lo que se encuentra en el mundo adulto y solo puede ser entendida su expresión estética como una etapa previa a la evolución estética hacia el mundo adulto. Si una estética particular representa una experiencia significativa que relaciona, visibiliza, proyecta y su ropa y accesorios constituyen extensiones culturales que ayudan a la tarea de regir la vida y ordenar las prácticas sociales (Rico, 1998), es posible entonces afirmar que el joven representado en esta serie, desde la búsqueda de una ética propia desde sus estéticas, tal como analiza Reguillo (2000), se encuentra más en un proceso transicional de caracterización que en un estado cristalizado del mismo, en tanto no recurre a una sola de las posibilidades de identificación particulares, sino que hace una construcción heterogénea de las estéticas para referirse así mismo y a los demás, haciendo no solo uso de la vestimenta, los accesorios sino además del lenguaje para ello. No es posible hablar de una sola juventud porque son los jóvenes diversos los que construyen las diferentes expresiones posibles de la juventud.

Siguiendo con lo propuesto con Reguillo, las estéticas juveniles están acorde al contexto en el cual se desenvuelven y pueden estar sintonizadas con este o, por el contrario, buscar la construcción de una propia identidad en contraposición al mundo adulto que lo 
rodea. Es en esta búsqueda de nuevos espacios que alimentan los esquemas identitarios, donde surge como categoría emergente la identificación del joven como agente de transformación social y cultural, en tanto el joven ocupa un espacio en el tejido que se construye desde la comunidad y genera nuevas dinámicas de acción desde y hacia los jóvenes. Su posición sociocultural se encuentra enmarcada en la relación que se establece desde los liderazgos que emprenden en la búsqueda de la resolución de los conflictos que aquejan a la comunidad de la cual se sienten miembros activos e importantes de la misma.

En ocasiones, las estéticas de algunos personajes acuden a una posición política particular frente a la vida, una más tendiente a los pensamientos de izquierda y se alinean hacia la resolución de los conflictos desde una postura más naturalista, en búsqueda de la resolución de las necesidades humanas, preocupados por la igualdad en todos los aspectos, incluyendo temas como el género. Aquí las estéticas, asociadas al vestir, a la música que se escucha (rock en español) remarcan la importancia que tiene para el joven colombiano el asumir una posición política que se funde con las propuestas éticas y estéticas de los géneros musicales que han transversalizado a los jóvenes en la construcción de una identidad propia, todo esto muy de la mano con lo que plantean Hormigos y Martin (2004) en cuanto a la construcción ética que se genera con la estructuración de unas subculturas particulares alrededor de los géneros musicales como el rock, el hip hop, entre otros. Como bien lo mencionan los autores, aunque estos jóvenes que pertenecen a la subcultura no engloban toda la juventud, también la construyen desde sus miradas y posibilidades y enriquecen el panorama de la representación del joven.

Como se ha mencionado, la serie se enmarcó en un momento social, político e histórico álgido de grandes cambios y transformaciones sociales como lo fue la década de los noventa en nuestro país. La asamblea nacional constituyente, el movimiento estudiantil de la séptima papeleta, la circunscripción y reconocimiento del apoyo y fomento de espacios para el desarrollo y cuidado de niños, niñas, adolescentes y jóvenes desde la estructuración de la nueva constitución política nacional, la reorganización de instituciones de fomento y construcción de ciudadanías que apuestan por el fortalecimiento de elementos de construcción de redes sociales y de avance en aspectos 
que mejoran la calidad de vida y los espacios de participación de los jóvenes en la sociedad. Es aquí, donde la intencionalidad de la serie al mostrar personajes fuertes desde el liderazgo, la construcción de tejido social y las implicaciones de los jóvenes en las posiciones políticas y públicas de la comunidad, cobra un nuevo sentido y una nueva comprensión, en tanto era necesario marcar la aparición de un joven que fuera participante más que espectador de la vida comunitaria y social, que comprendiera los modos y mecanismos que hacen posible la relación con los otros en un marco no regulado por una macro institucionalidad. El aporte, entonces, de la serie pasa por estar en sintonía con las necesidades reales de la sociedad en torno a los jóvenes, y que se traduce en una apuesta social mucho mayor y es el reconocimiento de las posibilidades del joven y de las relaciones que estos establecen para la superación de las situaciones que afectan a toda la comunidad.

Los escenarios de acción de la juventud se amplifican de manera progresiva y puede ser identificados en diferentes campos de acción. Desde lo local, pasando por lo nacional hasta lo global. Los eventos que se enmarcan en la serie pueden recibir diferentes lecturas acordes a los niveles sobre los cuales sus acciones tienen impacto. Desde lo local, por las transformaciones que llevan a cabo desde y para el barrio ficcional en el cual se enmarcan pueden ser extrapoladas a las posibilidades a los diversos entornos y barrios en la realidad sobre la cual se cimenta, desde lo nacional, en tanto generan un proceso particular de identificación de una manera de ser joven en nuestro país, con las características y posibilidades específicas que ello conlleva, desde lo global, porque aporta al desarrollo de nuevas miradas de lo juvenil en los espacios cotidianos alrededor del mundo y la manera de enmarcarse en las particularidades de una juventud cada vez más consciente de su papel en las transformaciones que se requieren.

Dentro de los aspectos que se buscaba analizar en esta investigación, se encuentra el tema de los actitudes y valores como parte de la representación que se construye de los jóvenes en la serie televisiva, siendo este parte constituyente de la dimensión cognitiva que se recoge en la teorización de las representaciones mediáticas. En los resultados de la investigación, se observa que las actitudes y valores que representan los jóvenes en la serie están cristalizadas en ellas y, por ende, desde el nivel de producción de las 
representaciones alrededor de la figura del joven, se puede configurar una dinámica que apunte a la influencia posterior sobre la posible audiencia que pueda consumir los contenidos. Sin embargo, y a diferencia de lo que plantean autores como Calonge o Tablante, las representaciones no necesariamente requieren de estar en circulación frente a una audiencia para poseer una carga simbólica y estructurar una visión particular de un grupo social o de las relaciones que se establecen entre los objetos sociales. Es posible entender una representación más allá de las prácticas e imaginarios que podría generar en una audiencia. Es el planteamiento del autor, escritor, guionista, el que estructura desde el nivel cognitivo aquello que se quiere representar en el medio audiovisual.

Aunque el análisis de la cultura presente en la obra audiovisual se escapa de los alcances planteados inicialmente en este trabajo, las dinámicas que se presentan en el barrio ficcional dan cuenta de un espacio que construye y reconstruye las representaciones que sobre los sujetos jóvenes en la obra se realizan y sobre las relaciones que éstos instauran con el entorno y con los demás personajes de la obra ficcional. En este sentido, y congruente por lo planteado por Feixa y Taguenca, el entramado cultural y social juega un papel importante en la manera de ser joven en la serie, y es posible brindar una mirada más global sobra las maneras en que estos se han estado construyendo.

Las relaciones que se establecen entre los jóvenes en la serie también dan cuenta de un elemento que los autores que han abordado el tema de juventud y el análisis de la manera en que esta se ha venido construyendo, en su gran mayoría, han estado pasando por alto: en la diferencia de caracteres es donde se enriquece la identidad grupal de la juventud. Son personajes con diferentes caracterizaciones, con motivaciones y distintas maneras de afrontar las dificultades, pero es desde aquí, en la relación que entre ellos establecen como grupo, en donde se configura una visión unificada y congruente de la juventud, tanto para ellos mismos que se identifican como pares, como para los adultos que los rodean y los definen, teniendo en cuenta, que las definiciones que hace el grupo de adultos relevantes en la serie sobre los jóvenes, depende de igual manera de las diferencias que existen entre los adultos, las posiciones sociales que ocupan en el conglomerado social propuesto en la serie. Aquel adulto con una posición 
dominante, de poder, que no tiene una relación positiva con el resto de la comunidad, percibe a los jóvenes como una amenaza para su posición y para las actividades que desarrolla para mantener bajo control la comunidad circundante. Por otra parte, los adultos que se encuentran en el otro lado del espectro, aquellos que se sienten particularmente perjudicados por este personaje, apoyan a los jóvenes en las actividades que estos emprenden.

Desde Feixa, es el entramado social, incluyendo las instituciones que pertenecen al sistema cultural, junto a las imágenes culturales propias que circulan en los medios, quienes dotan de sentido el concepto de juventud. En este caso, las imágenes culturales de la juventud son las que hacen su aparición y marcan el devenir de la juventud en los espacios sociales en los cuales colocan su accionar en práctica. Las instituciones aquí no aparecen como un elemento mediatizador de la juventud y su influencia sobre el este grupo social no es tan relevante para el análisis de una condición particular de Juventud.

En cierta forma, Taguenca delineó en sus trabajos la importancia de las relaciones, en tanto planteó que la Juventud está definida desde el conjunto de relaciones que se establecen alrededor de un grupo de individuos que comparten algunas características específicas (algunas de ellas asociadas a un ítem etario) y aquellos miembros de la comunidad, a la que se circunscribe este grupo, que no comparten esta característica fundamental, sin embargo, brindan contexto y soporte desde las tensiones que se generan en estas relaciones, tanto positivas como negativas. Solo a través de los demás y el entorno, el joven es y se construye. Según la propuesta de esta investigación, no es posible entender al joven y las representaciones que de él se construyen, aun en un entorno ficcional, sin entender que hace parte de un conglomerado social que lo construye, reconstruye y moldea de acuerdo a las necesidades presentes en la comunidad y las características base de las cuales estos jóvenes echan mano.

El joven de "Cartas a Harrison" es un ser plural, representado en cada una de las expresiones posibles en el contexto social y cultural de los 90: un joven con ambiciones, sueños, aspiraciones, incorporado a una realidad social circundante y consciente de la necesidad de participar de la vida comunitaria y social del entorno que le corresponde. 
No evita, ni evade la responsabilidad que sobre él esperan y asumen los adultos que entran en contacto con ellos, inclusive, aquel que se muestra reacio a aceptar la participación de estos en la vida social de la comunidad. Aún este personaje, con su actitud frente a los jóvenes, ayuda a definir lo que son y lo que hacen los jóvenes en esta comunidad ficcional. Como señalaría Reguillo (2007) el entorno tanto positivo como negativo, da sentido y contexto a la juventud en el medio social.

Siguiendo el argumento anteriormente expuesto, las tensiones que se relatan desde el mundo ficcional de la serie, dan cuenta de la convivencia del mundo adulto con el mundo joven y como ambos se retroalimentan entre sí, brindando forma y cohesión social a la comunidad que en la serie es representada. Margulis y Urresti (1998), plantearon la posibilidad de la existencia de esta relación positiva entre adultos y jóvenes, como una forma de brindar elementos de construcción de la condición juvenil no desde lo patológico sino, por el contrario, desde lo positivo y con miras a ampliar el espectro de participación del joven de la vida comunitaria. En lo encontrado en esta investigación, se da elementos de análisis posteriores para hallar, efectivamente, una relación de carácter positiva entre los adultos y los jóvenes, toda vez que es a través de esta relación en donde se enmarca la construcción del joven como un elemento pilar en la narrativa ficcional que presenta la obra audiovisual. El joven es parte vital del engranaje social y logra acaparar las prácticas sociales que construyen comunidad desde las acciones más sencillas hasta las más complejas.

Cabe también decir que, aunque no es un objetivo esperable dentro de lo planteado inicialmente en la investigación, igualmente en este trabajo se hace un recorrido por la presencia del joven en los medios de comunicación, ya sea como generador o como audiencia. Es importante mencionar aquí el valor comunicativo que alcanza la obra audiovisual sobre estos jóvenes en este entorno ficcional particular en nuestra televisión colombiana. Las prácticas comunicativas de los jóvenes se ponen de manifiesto en la narrativa, en la estructura dramática y en los recursos a los que recurren, para atender y solucionar las dificultades a las que se ven enfrentados. 


\section{CONCLUSIONES}

En el extenso recorrido que ha tenido esta investigación es importante resaltar varios puntos para dar un cierre a lo que en estas páginas se plantea. Por una parte, se hace necesario ampliar las investigaciones alrededor de la figura del Joven en la televisión colombiana que, aunque existen algunas menciones al respecto del tema, lo relacionan más con la infancia y la juventud como una extensión de esta y no reconocen el carácter unitario y especifico de la juventud como suficiente para ser analizada a profundidad, incluso, más allá de los estudios de audiencias y recepción, enfocarse en las apuestas que podrían enriquecer los distintos elementos de construcción social alrededor de la juventud como sujetos sociales de interés para nuestros medios de comunicación. Esto conlleva varios retos teóricos, conceptuales y metodológicos.

La representación mediática, como base teórica para la aplicación en estudios investigativos en los medios de comunicación, aún se encuentra en un proceso de desarrollo que necesita más y mejores aportes que sirvan para clarificar los límites y alcances de los mismos y la manera en que se distancia de aquellos provenientes de las representaciones sociales que tienen más asiento en ámbitos de medios multimodales (como la prensa y la opinión pública) que aquellos que involucran la integración de muy diversos canales comunicativos con semiosis distintas (caso la televisión, el cine, los productos multimedia).

Como se expresa en el capítulo II, en relación a las características de la representación mediática, esta puede ser construida desde los propios contenidos que circulan en un producto audiovisual, sin que para ello medie la reconstrucción de una audiencia particular. Es el creador de la obra audiovisual quien plasma un referente particular con características y elementos que pueden remitir a un contexto ya existente, pero que no necesariamente encaje con los elementos que ya se encuentran circulando en el entorno sociocultural en el cual se transmite. La representación del joven en "Cartas a Harrison" 
existe y está ahí para ser aprehendida por quienes accedan al contenido, aunque ya la audiencia original a la que se encontraba dirigida no comparta las características de aquella a la que podría acceder en la actualidad a tales contenidos, por tanto, esto podría llegar a ser considerado como una posible variable dentro de la construcción teórica de la representación mediática.

Por otra parte, es importante señalar que las características de las representaciones en los medios debe ser ampliada y no limitada a dos momentos del producto audiovisual como la han venido planteando los autores que han abordado esta tarea: la producción y el consumo, sino que, además, elementos como la permanencia y relevancia de las representaciones contenidas en los productos audiovisuales y su resonancia en audiencias actuales y futuras, puede ser un interesante camino a recorrer tanto en lo conceptual como en lo metodológico.

En los resultados se permite concluir que la representación mediática que se construye de la juventud es una representación que se cimienta en la función social que cumplen, las acciones que adelantan y que influyen sobre el medio y que se da en contraposición de una imagen del adulto responsable, influyente sobre el medio y el ambiente sobre el que tiene acceso. Entonces, la posición sociocultural que ocupa el joven en lo que nos muestra la serie, es relevante para la dinámica del barrio y las problemáticas que en éste se presentan.

"Cartas a Harrison" se constituye en una mirada distinta del joven en Colombia, una mirada que aun en el presente no ha logrado volver a ser retomada por los productores de contenido televisivo y mediático de nuestro país: No es una mirada mediatizada por una "industria" televisiva con agendas particulares o una construida desde el cliché y el estereotipo de la agencia adulta sobre lo que significa o es el joven. Esta serie, más allá de los caminos explorados durante la construcción de esta investigación (del joven como audiencia o como generador de contenido), intenta generar un relato antropológico, sociológico y ecológico de aquel joven que encuentra poca representatividad en las narrativas culturales en nuestra televisión: un joven que no es pobre, violento, que no está mediado por instituciones de carácter educativo, religioso o político y que construye (y en el proceso se reconstruye) en su hábitat natural, su entorno, su barrio. La 
intencionalidad con que se funda este relato escapa de los alcances naturales del presente trabajo.

La serie, en sí, se convierte en un vehículo que sirve para mediatizar una apuesta por una juventud no homogénea, que piensa en torno a las necesidades que se requieren solventar para afrontar procesos de cambio y transformación social desde las posibilidades que brindan los territorios en nuestro país. Presenta las diferencias compartidas entre los jóvenes como un elemento que, lejos de minimizar o simplificar el acercamiento de las juventudes a los elementos contextualizadores del entorno en el cual crecen y sobre el cual se agrupan y actúan, lo enriquecen y complejizan en tanto no se presenta un solo abordaje de la realidad contextual, sino que a partir de las propias diferencias cada uno gestiona una relación que enriquece las posibilidades con las que se abordan las problemáticas sociales y culturales del territorio particular sobre el cual actúan. Con las herramientas de las que disponen y colocando ante si las diversas alternativas de las que pueden echar mano, la juventud en "cartas a Harrison" estructura una agenda comunicadora acorde a los intereses de la comunidad en donde se inserta de manera muy natural los intereses propios y particulares de cada uno de los personajes que participan en este proceso, se convierte en caja de resonancia, plantea y estructura mecanismos para modificar aquello que necesita ser modificado, para apostar por el bienestar y el beneficio de todos en el territorio sobre el cual intervienen. Es una invitación a través de la representación de esta condición de joven, a actuar, a modificar aquello que afecte las vidas de las comunidades y que los jóvenes aporten desde sus propias identidades.

Es interesante ver que en esta serie no existe una sola y única lectura de la representación de la juventud y es más cercano referirse a las "representaciones" de las juventudes en tanto muestra que, aunque existen factores y elementos de cohesión que los identifica frente a un grupo más amplio (los adultos de la comunidad), cada uno de los personajes que se muestran en la serie asumen de manera diferencial el ser joven en un mismo contexto y bajo unas mismas condiciones sociales, culturales y económicas. Estos personajes crecieron juntos bajo estas condiciones, cuestión que los llevo a cohesionarse y en muchas ocasiones, ejercer un ejercicio coherente frente a las 
dificultades y problemáticas que el adulto antagonista les plantea; sin embargo, sus particularidades se hacen evidentes en los tonos y las formas de comunicarse entre ellos y con los que no pertenecen a su grupo social.

Respecto al análisis y al campo disciplinar, es importante proseguir con trabajos y análisis que permitan ahondar en la producción y reproducción de representaciones en los medios, campo que aún se encuentra bastante inexplorado. Ello, desde dos aspectos: En primera instancia, trabajar representaciones será mucho más útil si existen mayores acercamientos a la comprensión de la recepción de estas representaciones: cómo, cuándo y en qué contextos consumen los jóvenes y los adultos las representaciones y los estereotipos que les son propuestos a través de la televisión y canales multimediales, permitirá ahondar en los mismos procesos de construcción de identidades, comprender los procesos de reproducción de prejuicios, entre otras.

De igual forma, se convertiría en un buen punto de partida, la búsqueda de las relaciones que se establecen entre las representaciones que de si construyen los jóvenes, frente a lo que se pueden encontrar en las de los medios de comunicación y las que, de manera hegemónica, se han estado reproduciendo en nuestra sociedad respecto a quienes son los jóvenes y qué quieren.

En cuanto a los aportes que esta investigación realiza frente a la línea de investigación Narrativas, representaciones y tecnologías mediáticas de la Maestría en Comunicación, Desarrollo y Cambio Social, se pueden encontrar algunos puntos a resaltar. Por una parte, la búsqueda de representaciones en los contenidos audiovisuales de nuestra producción televisiva, puede ser un camino interesante para abordar históricamente desde los medios, problemáticas que como sociedad aun nos afectan y que inciden en el desarrollo de políticas públicas y procesos de comunicación dirigidos hacia el cambio y la transformación social. El estudio de estas representaciones, desde la línea investigativa, permitiría brindar herramientas teóricas y metodológicas que sirvan para alimentar y fortalecer un corpus de un elemento cada vez más presente en la tradición investigativa de la comunicación en América Latina como lo es el de las representaciones mediáticas. De esta manera, también sirve para apuntalar algunas perspectivas de la Maestría en cuanto a faro de referencia en el abordaje de estas representaciones y mecanismos para 
estudiarlas. Se pretende así, generar interés alrededor de las temáticas referentes a representaciones, y aun más allá de esto, en el acercamiento a la condición de juventud, a la cual se puede aportar significativamente desde los elementos que brinda tanto la línea de investigación como la Maestría como programa académico posgradual. 


\section{Recomendaciones}

Para futuras investigaciones, se recomienda ampliar el espectro metodológico que podría ser utilizado para el estudio y abordaje de las representaciones presentes en los medios de comunicación, en particular, los referentes a aquellos que utilicen diferentes canales comunicativos como lo son la televisión, el cine y los nuevos formatos multimediales, incluyendo los productos dirigidos hacia la web.

Uno de las hallazgos en la búsqueda de estrategias y las alternativas metodológicas para abordar el objeto de esta investigación es que las opciones para abordar los contenidos multimodales, como es el caso de la televisión, son múltiples y en algunos casos muy complejos, por lo que se recomienda que estas metodologías (como es el caso del análisis multimodal), sean aplicadas en investigaciones de largo aliento que permitan elaborar mapas al detalle de aquello que se quiere estudiar y que integre los diversos canales semánticos y semióticos que en ellos convergen.

Por otra parte, sería interesante generar una dinámica de investigación tendiente a revisar el manejo de las representaciones cristalizadas en productos audiovisuales de otras épocas en audiencias modernas, para abordar y estudiar los procesos que podrían darse en la recirculación de representaciones que puedan diferir de las características de las nuevas audiencias y así visualizar el impacto sobre la comunicación entre el medio y la audiencia, a partir de los contenidos. Esta característica de las representaciones, la de la permanencia en el tiempo independiente de la audiencia a la que haya sido dirigida, debe ser más ampliamente indagada y explorada por futuras investigaciones.

Una de los aspectos de interés que se puede suscitar a partir del análisis de la serie "Cartas a Harrison" como producto comunicacional, es que esta lleva interesantes elementos que bien podrían conllevar a futuras investigaciones sobre las narrativas en la televisión colombiana, no solo en aquellas que se centran en la figura del joven, sino en cualquier grupo social. Uno de estos elementos puede ser la manera en que se mediatiza la figura de los distintos grupos sociales con relación al contexto en el que se crean y se generan los contenidos disponibles en los canales en los que son transmitidos estos productos. 
Se debe considerar la posibilidad de empezar a tender puentes entre las representaciones que construyen los jóvenes sobre si mismos en la práctica social continua y permanente, frente a lo que se pueden encontrar en las de los medios de comunicación y las que, de manera hegemónica, se han estado reproduciendo, generalmente desde otros grupos sociales, en nuestra sociedad al respecto de que y quienes son los jóvenes. Realizar estudios que apunten a esta tarea, también permitirá establecer elementos constitutivos de procesos de identidad por inclusión o rechazo de las mismas representaciones. 


\section{Bibliografía}

Adoni, H., y Mane, S. (1984). Media and the social construction of reality. Communication Research, 11, 323-340

Aguaded, J. I. (2000). Televisión y telespectadores. Huelva, Grupo Comunicar.

Alsina, M. R. (1993) La Construcción de la Noticia. Barcelona: Paidós.

Amossy, R.; Herschberg Pierrot, A. (2001) Estereotipos y clichés, Eudeba Editorial Universitaria de Buenos Aires, Buenos Aires

Aparici, R. (2010). “Introducción: la educomunicación más allá del 2.0”, en AA.DD. Educomunicación: más allá del 2.0. Barcelona: Gedisa.

Arango, G. y González, M.I. (2009). Televidencias juveniles en Colombia: fragmentación generada por un consumo multicanal. En Palabra Clave, Vol.12.2, pp. 215-234. Bogotá.

Araya, S. (2002). Las representaciones sociales: ejes teóricos para su discusión, Cuadernos de Ciencias Sociales n. ${ }^{127}$, San José de Costa Rica, F'LACSO

Aristizábal, V. (1996). Los jóvenes y la televisión. En Revista de Ciencias Humanas, Vol. 03.7, pp. 93-98. Pereira.

Bacallao Pino, Lázaro M. (2010) "Representaciones mediáticas de las redes sociales: un estudio de casos", en Revista Latina de Comunicación Social, 65, páginas 114 a 125. La Laguna (Tenerife): Universidad de La Laguna, recuperado el 17 de junio de 2014, de http://www.revistalatinacs.org/10/art/887_UZaragoza/09_Lazaro_Bacallao.html Barker, Ch. (2003). Televisión, globalización e identidades culturales. Barcelona, Paidós. Brabo, J.M. (2011). Contenido y estructura de Representaciones Sociales sobre Pedagogía y pedagogos en profesores de ciencias. Tesis Doctoral. Universidad de Burgos, España. Recuperado de: http://dspace.ubu.es:8080/tesis/handle/10259/161?mode=simple

Brake, M. (1980): The Sociology of Youth Culture and Youth Subcultures: Sex and Rock'n'Roll. Londres: Routledge and Kegan Paul.

Briñol, P.; Falces, C.; Becerra, A. (2007). Actitudes. En Psicologia Social. Editorial: McGraw-Hill. Madrid, España

Buckingham, B. (2002). Crecer en la era de los medios electrónicos. Madrid: Morata. 
Calonge, S. (2006). La representación mediática: teoría y método. Revista da Psicologia da Educação (23), p.75-102.

Casseti, F. y DiChio, F. (1999). Análisis de la televisión: instrumentos, métodos y prácticas de investigación. Barcelona: Paidós.

Castoriadis, C. (1975). La institución imaginaria de la sociedad. Tusquets Editores: Barcelona

Dayan, D., and Katz, E. (1992). Media Events: The Live Broadcasting of History. Cambridge: Harvard University Press. Reimpreso por Harvard University Press (1994).

De Fleur, M. L. y Ball-Rokeach (1993). Teorías de la comunicación de masas. Barcelona, Paidós. $2^{\mathrm{a}}$ ed.

Departamento Administrativo Nacional de Estadística [DANE]. (2015). Encuesta de Consumo Cultural. Recuperado de: http://www.dane.gov.co/files/investigaciones/eccultulral/presentacion_ecc_2014.pdf

Duarte-Duarte, J. y Jurado-Jurado, J. C. (2016). Consumo televisivo de padres y niños y recepción de las representaciones de autoridad agenciadas por la televisión. Palabra Clave, 19(2), 607-629.

Durkheim, E. (1992). Las formas elementales de la vida religiosa (Vol. 38). Ediciones Akal. México.

Eco, U. (1985). Innovation and Repetition: Between Modern and Post-Modern Aesthetics. Daedalus, Vol. 114, No. 4, The Moving Image (Otoño, 1985), pp. 161-184

Egri, L. (1946). The art of dramatic writing. Its basics in the creative interpretation of human movies. New York: Touchstone book.

Feixa, C. (2006). Generación XX. Teorías sobre la juventud en la era contemporánea. Revista Latinoamericana de Ciencias Sociales, Niñez y Juventud, 4(2). Universidad de Manizales. Disponible en línea: http://biblioteca.clacso.edu.ar/Colombia/alianza-cindeumz/20131029044835/art.CarlesFeixa.pdf.

Filho, J.F. (2004). Por uma nova agenda de investigação da história da TV no Brasil Dossiê 40 anos de understanding media Contracampo. Niterói. 10/11:201-218.

Galán Fajardo, E. (2007). Fundamentos básicos en la construcción del personaje para medios audiovisuales. CES Felipe II. 
Garcés, Á.; Patiño, C., y Torres, J. J. (2008), Juventud, investigación y saberes. Estado del arte de las investigaciones sobre la realidad juvenil en Medellín 2004-2006. Medellín, Sello Editorial Universidad de Medellín.

García, D. y Carlos, M. (2016). Historias de la televisión en Colombia: vacíos y desafíos. Revista Comunicación y Sociedad. Universidad de Guadalajara. Nueva época, núm. 26, mayo-agosto, 2016, pp. 95-121.

Habermas, J. (1999). "Sistema y mundo de la vida", en Jürgen Habermas, Teoría de la acción comunicativa, Madrid, Taurus, Vol. II, pp. 161-280.

Hall, S. (1997). The work of representation. In S. Hall (Ed.), Representation: Cultural representations and signifying practices (pp. 13-64). London: Sage.

Herrán, M. (1991). La industria de los medios de comunicación en Colombia, Bogotá, Fescol.

Hormigos, J. y Martin, A. (2004). La construcción de la identidad juvenil a través de la música. Revista Española de Sociología, 4 (2004), pp. 259-270

Igartua, J.J. (2006). Métodos cuantitativos de investigación en comunicación. Barcelona, Bosch.

Informe regional de población en América Latina y el Caribe 2011. Invertir en Juventud. (Jun, 2012). CEPAL/UNFPA. 140 pp.

Izco, E. (2007). Los adolescentes en la planificación de medios. Segmentación y conocimiento del Target. tesis defendida en la Facultad de Comunicación de la universidad de navarra. directores: Idoia Portilla Manjón y Francisco Javier Pérez Latre. Leída: 20 de septiembre de 2015. Premio Injuve a tesis doctorales.

Jodelet, D. (2003) "Représentations sociales: un domain en expansion", en D. Jodelet (ed.) Les representations socials. París: PuF.

Kientz, A. (1974). Para analizar los mass media. Valencia, FernandoTorres.

KienyKe. (2013). Las series que veíamos en los 90. [online] Disponible en: http://www.kienyke.com/tendencias/las-series-que-veiamos-en-los-90/ [Recuperado el 12 oct. 2015].

Krippendorff, K. (1990). Metodología del análisis de contenido. Teoría y práctica. Barcelona, Paidós.

Krippendorff, K. (2013). Content analysis: an introduction to its methodology. LosAngeles/London, Sage. 
Lacalle, C. (2014). Jóvenes y ficción televisiva: Construcción de identidad y transmedialidad. Editorial UOC. Barcelona.

Lara, K. (2008). Consumo de televisión y cultura política. (Tesis para Grado Licenciatura en Ciencias de la Comunicación Universidad de las América Puebla) Recuperado de: http://catarina.udlap.mx/u_dl_a/tales/documentos/lco/lara_r_k/

Lazarsfeld, P y Merton, R. (1977). Comunicación de masas, gusto popular y acción social organizada. Publicado en MURARO, Heriberto (comp.). La comunicación de masas, Centro Editor de América Latina, Buenos Aires

Loaiza, J., Rosas, M.L., Otero, A. (productores) y Triana, J. (director) (2014). Televisión Colombiana. 60 años. [Documental]. CO: Señal Colombia.

López, M. (2010). Contexto y Condición de juventud: Reflexiones para su comprensión. En Cuaderno $n^{\circ} 4$. Serie Cuadernos de Animación Sociocultural. Editorial Mónica Sepúlveda - Escuela de Animación Juvenil. Medellín, Colombia.

López, M. (2010). Contexto y Condición de Juventud: Reflexiones para su comprensión. Serie Cuadernos de Animación Sociocultural. Escuela de Animación Juvenil. Medellín, Colombia.

Luckmann, T., y Berger, P. L. (1968). La construcción social de la realidad. Buenos Aires: Amorrortu.

Margulis, M. (ed.) (1996). La juventud es más que una palabra. Buenos Aires: Biblos. Margulis, M. (2015). Juventus o Juventudes: Dos conceptos diferentes. En Revista Voces en el Fénix. Año 6 Numero 51, pp, 6-13. Buenos Aires.

Margulis, M. y Urresti, M. (1998). La construcción social de la condición de juventud, en H. Cubides (ed.), Viviendo a toda. Jóvenes, territorios culturales y nuevas sensibilidades, Santa Fe de Bogotá, Siglo del Hombre Editores.

Markova, I. (2000) "Ameédée or how to get rid of it: social representations from a dialogical perspective", Culture and psychology. 6 (4): 419-460

Martín Serrano, M. (1993). La producción social de comunicación. Madrid: Alianza Editorial.

Martín-Barbero, J. (2001), Claves de debate: televisión pública, televisión cultural: entre la renovación y la invención, Bogotá, Fundación Friedrich Ebert, Centro de Competencia en Comunicación para América Latina, Disponible en línea http://library.fes.de/pdffiles/bueros/kolumbien/04199.pdf 
Martín-Barbero, J. (2006). Colombia: Medios y Cultura. Revista Todavía. № 13. Recuperado el 30 de mayo de 2014, de http://www.revistatodavia.com.ar/todavia13/notas/barbero/txtbarbero.html

Martínez, V. (2013) Paradigmas de la investigación. Manual multimedia para el desarrollo de trabajos de investigación. Una visión desde la epistemología dialéctico crítica. p 8.

Medina, A., Villa, C., y Franco, G. (2003). Evaluación del impacto en televisión: el caso de Muchachos a lo bien. Medellín: Fundación Social.

Medrago, C., Airbe, A. y Palacios, S. (2010). El perfil de consumo televisivo en adolescentes, jóvenes y adultos: implicaciones para la educación. En Revista de Educación, 352, pp.545-566. Madrid.

Medrano Samaniego, C. (2006). El poder educativo de la televisión. Revista de Psicodidáctica, 11()93-107. Recuperado de http://www.redalyc.org/articulo.oa?id=17514747007

Morley, D. (1996). Interpretar televisión: la audiencia de Nationwide. En Televisión, audiencias y estudios culturales, Amorrortu, Buenos Aires, 1996, pp. 111-147

Moscovici, S. (1961) La psychanalyse, son image et son public. París: PuF. Moscovici, S. (1979). El psicoanálisis, su imagen y su público. Huemul. Buenos Aires, Argentina.

Moscovici, S. (1984) "Introduction: Le domaine de la psychologie", en S. Moscovici (ed.) Psichologie Sociale. París: PuF.

Muñiz, C. e Igartua, J. J., (2004) "Encuadres noticiosos e inmigración. Un análisis de contenido de la prensa y TV españolas", revista Zer, $n^{\circ} 16$, mayo 2004, Bilbao

Muñoz, G. (2007). "La comunicación en los mundos de vida juveniles", en: Revista Latinoamericana de Ciencias Sociales, Niñez y Juventud, No. 1, Vol.5, Manizales, Cinde, enero-junio.

Naval, C., Sabada, C. (2005). Introducción: Juventud y medios de comunicación frente a frente. Revista De Estudios De Juventud. Marzo 05 no 68. Injuve.

Ortega, F. y Galhardi, C. (2013) Propuesta metodológica para el análisis de contenido de la parrilla de televisión en Brasil: Análisis de un caso práctico en los Estados de São Paulo, Rio Grande do Sul, Estado da Bahía. En: CONGRESO NACIONAL SOBRE METODOLOGÍA DE LA INVESTIGACIÓN EN COMUNICACIÓN Y DEL SIMPOSIO INTERNACIONAL SOBRE POLÍTICA CIENTÍFICA EN COMUNICACIÓN, Segovia. Anais 
electrônicos... Segovia. Disponible en: htpp://dialnet. unirioja.es/servlet/articulo?Codigo $=4228799$

Palacio, M. (2001). Historia de la Televisión en España. Editorial Gedisa S.A. Barcelona Pardo Abril, NG. (2012). Metáfora multimodal: representación mediática del despojo. Forma y Función, 25() 39-61. Recuperado de http://www.redalyc.org/articulo.oa?id=21928398002

Parker, P. (2003). Arte y técnica del guión, una completa guía de iniciación y perfeccionamiento para el escritor. Barcelona, Ediciones Robinbook.

Pedraza González, D.M (2008). La representación mediática y perspectiva de derechos de la niñez en Colombia. Editorial U. Externado de Colombia.

Pérez, M. y Vega, J. (2010). Memorias de organizaciones juveniles, comunicación e identidades políticas. Estudio de caso del Colectivo Pasolini en Medellín. En: Pensar la Comunicación II (pp. 148 - 169). Medellín: Universidad de Medellín.

Piñuel, J. L. (2002): «Epistemología, metodología y técnicas del análisis de contenido», en Estudios de Sociolingüística,3(1), pp.1-42

Poloniato, A. (1992). Los formatos Televisivos. En ILCE (coord.) Géneros y formatos para el guionismo en televisión educativa. (pp. 151-198) México. Ed. ILCE.

Protagonismo juvenil en proyectos locales. Lecciones del Cono Sur (pp. 73-87). Santiago de Chile, DF: Organización de las Naciones Unidas.

Ramírez, D. G., y Barbosa, M. C. (2016). Historias de la televisión en Colombia: vacíos y desafíos. Comunicación y Sociedad, (26), 95-121.

Ramírez, L. (2000). El gobierno de Rojas y la inauguración de la televisión: Imagen Política, educación popular y divulgación cultural. Historia Crítica. No.22. Recuperado desde: http://historiacritica.uniandes.edu.co/view.php/403/index.php?id=403 Ramírez, L. (2000). El gobierno de Rojas y la inauguración de la televisión: Imagen Política, educación popular y divulgación cultural. Historia Crítica. No.22. Recuperado desde: http://historiacritica.uniandes.edu.co/view.php/403/index.php?id=403 Ramos, A. y Fernández, J.L. (2011). Ficcionar al otro: imaginarios, inclusión y presencia de las Minorías religiosas en las series de ficción españolas. Revista Electrónica Razón y Palabra. $\quad N^{\circ}$ 78. México. Recuperado de: https://webcache.googleusercontent.com/search?q=cache:eHjwMg1i5ZUJ:www.razonypa 
labra.org.mx/varia/N78/2a\%2520parte/32_RamosFernandez_V78.pdf+\&cd=1\&hl=es419\&ct=clnk\&gl=co

Reguillo, R. (2004). "La performatividad de las culturas juveniles". En Revista de Estudios de Juventud, ํo 64: 49-56.

Rey, G. (2001). El escenario móvil de la televisión pública. Algunos elementos de contexto. Televisión pública: del consumidor al ciudadano. pp. 72-103. Convenio Andrés Bello: Bogotá.

Rey, G. (2002). La televisión en Colombia. En G. Orozco (Coord.), Historias de la televisión en América Latina. Barcelona, España: Gedisa.

Rey, G. (2004). La pobreza en las páginas de El Tiempo. Bogotá: El Tiempo, PNUD.

Rivière, M. (2003). El malentendido. Cómo nos educan los medios de comunicación. Barcelona, Icaria.

Rocher, G. (1980). Introducción a la Sociología General. Barcelona, Herder. $7^{\text {a }}$ ed.

Rodríguez, J. C. (2001). Participación juvenil y ciudadanía, en VV.AA. In Comisión Económica para América Latina y el Caribe \& Organización de las Naciones Unidas.

Rodríguez, M. (2012). Palimpsestos: mapas, territorios y representaciones mediáticas. Revista Virtual "Reflexiones Marginales" $N^{\circ} 10$. Argentina. Recuperado de: http://v2.reflexionesmarginales.com/index.php/num10-dossier-blog/213-palimpsestos-

mapas-territorios-y-representaciones-mediaticas

Rouquette, M.-L. (1994). Sur la connaissance des masses. Essai de psychologie politique. Grenoble: Presses Universitaires de Grenoble.

Sánchez, J. L. (1997). Crítica de la seducción mediática. Madrid, Tecnos.

Sánchez, L.; Megías, I. y Rodríguez, E. (2004). Jóvenes y publicidad. Valores en la comunicación publicitaria para jóvenes. Madrid, FAD/INJUVE

Sandoval, M. (2006). Los efectos de la televisión sobre el comportamiento de las audiencias jóvenes desde la perspectiva de la convergencia y de las prácticas culturales. En Universitas Psychologica, Vol. 05.2, pp. 205-222. Bogotá.

Schutz, A., y Mèlich, J. C. (1993). La construcción significativa del mundo social: introducción a la sociología comprensiva. Barcelona: Paidós.

Seger, L. (1990) Cómo crear personajes inolvidables/Guía práctica para el desarrollo de personajes en cine, televisión, publicidad, novelas y narraciones cortas. Barcelona: Editorial Paidós. 
Sosa, D.H. (2013). Una Bogotá Imaginada desde la pantalla. Universidad Jorge Tadeo Lozano. Expeditio.

Tablante, L. (2005). Representaciones sociales, medios y representaciones mediáticas. Revista Temas de comunicación (12). Centro de Investigación de la Comunicación de la Universidad Católica Andrés Bello. Caracas, Venezuela. Recuperado el 22 de agosto de 2015.

Disponible en línea http://biblioteca2.ucab.edu.ve/anexos/biblioteca/marc/texto/AAD9233_12.pdf

Tablante, L. (2008). Pobreza en su tinta: Representaciones periodísticas de la pobreza en Venezuela. Trabajo de Ascenso, Universidad Católica Andrés Bello, Caracas.

Tablante, L. (2009). Pobreza en la prensa venezolana: representaciones estacionarias. Comunicación: Estudios venezolanos de comunicación, (147), 86-95. Recuperado el 17 de agosto de 2015. Disponible en línea http://gumilla.org/biblioteca/bases/biblo/texto/COM2009147.pdf.

Tablante, L. (2011). Pobreza en la prensa venezolana: crónica de una tormenta, por Leopoldo Tablante. Revista Electrónica Prodavinci. Recuperado el 9 de agosto

Taguenca, J. A. (2009), "El concepto de juventud", Revista Mexicana de Sociología, 001, pp. 159-190.

Tomasi, L. (1998). “Adolescence/youth culture”, en William H. Swatos, e.d., Encyclopedia of Religion and Society, Walnut Creek, Rowman Altamira Press, pp. 3-7

Triana, J. (2014) "60 años al aire”. [Documental] País: Colombia.

Universidad de Antioquia. Facultad de Derecho (2003). Guía de curso "Formación ciudadana y Constitucional. Medellín, Colombia.

Urcola, Marcos (2003). "Algunas apreciaciones sobre el concepto sociológico de juventud". En Revista Invenio. Rosario: UCEL, noviembre, N 11, pp. 41-50.

Urcola, M. (2003). Algunas apreciaciones sobre el concepto sociológico de juventud. Revista Invenio. 6 (11).

Urteaga, M. (2005). "Los debates teóricos desde la perspectiva sociocultural sobre los derechos de las y los jóvenes", ponencia en Seminario Defensa y Protección de los Derechos Juveniles en la Ciudad de México, 2005, Disponible en línea (www.inicia.org). Urteaga, M. (2007). "La construcción juvenil de la realidad. Jóvenes mexicanos contemporáneos", tesis doctoral en ciencias antropológicas, México, UAM, 2007. 
Urteaga, M. (2009). "Juventudes, culturas, identidades y tribus juveniles en el México contemporáneo", en: Diario de Campo. Boletín Interno de los Investigadores del Área de Antropología, suplemento núm. 56, INAH, octubre-diciembre de 2009.

Valencia, S. (2007). Elementos de la construcción, circulación y aplicación de las representaciones sociales. En Representaciones Sociales, Teoría e Investigación. Rodriguez, T y Garcia, M.L. (Coord.). Universidad de Guadalajara, México. Vasilachis, I. (1997) "El pensamiento de Habermas a la luz de una metodología propuesta de acceso a la teoría", Revista Estudios Sociológicos, Vol. XV, Núm. 43, (enero-abril, 1997), Colegio de México, 30 pp. Extraído [el 13 de julio de 2016] de: codex.colmex.mx:8991/F/?func=service\&doc

Vega Montiel, A. (2010). La responsabilidad de la televisión mexicana en la erradicación de la violencia de género contra las mujeres y las niñas: apuntes de una investigación diagnóstica. Comunicación y sociedad, (13), 43-68. Recuperado en 28 de mayo de 2014, de http://www.scielo.org.mx/scielo.php?script=sci_arttext\&pid=S0188252X2010000100003\&lng=es\&tlng=es.

Vega, J. (2006). Estado del arte de los programas de prevención de la violencia en jóvenes, basado en el uso de los Medios de Comunicación. Pan American Health Organization (OMS), Cooperación Técnica Alemana-gtz disponible en: http://www.paho.org/spanish/ad/fch/ca/ca_comuni-cacion.violencia.pdf. Recuperado: 5 de abril de 2016.

Vera, J. (2005): Medios de comunicación y socialización juvenil. Revista Juventud, n 68, Madrid. Instituto la la Juventud, URL:(www.injuve.mtas.es/injuve/contenidos.downloadatt.action?id=1590639627, consulta: 15 de septiembre 2015

Villa Orrego, NH. (2012). "Televisión, jóvenes y políticas públicas. Aspectos clave de una relación que contribuye al desarrollo social.". En: España Eticanet - Revista Científica Electrónica De Educación Y Comunicación En La Sociedad Del Conocimiento. Ed: Universidad De Granada. v.1.

Willem, C. (2011). Minorías en red. Medios y Migración en Europa. Barcelona: Transmedia XXI. Universitat de Barcelona. 